\title{
Sowing the Gospel of Peace: Missionary James Watkin at Karitāne and Wellington, 1840-1855
}

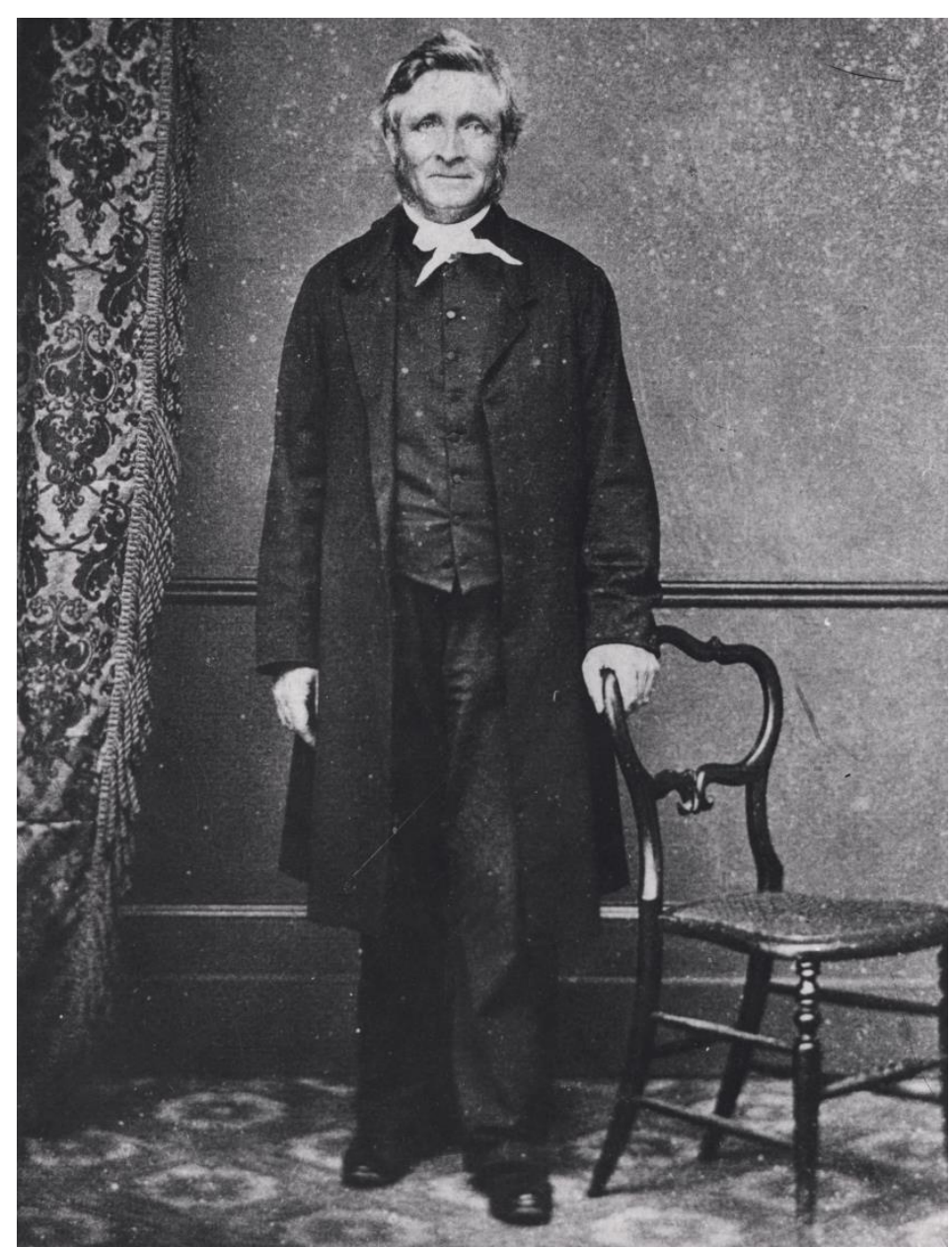

James Watkin photograph, c.1863, Portraits_W_049A, Hocken Collections, Uare Taoka o Hākena, University of Otago, New Zealand.

A thesis submitted to the Victoria University of Wellington in fulfilment of the requirements for the degree of

Master of Arts in History

Victoria University of Wellington

Mary-Anne Woodfield 



\section{Abstract}

Wesleyan missionary James Watkin established the first mission station in the South Island at Karitāne in May 1840 and in 1844 he shifted to Wellington, where he remained with his family until 1855. During this time Watkin recorded his mission work in his journal, a key primary source for this research. While his efforts as a missionary have been considered particularly in texts covering New Zealand mission and South Island history, this thesis focuses on how James Watkin's work helped to encourage physical and moral peace where he was located. Key elements of this work involved running church services for Māori and Europeans, and commencing schools at which Māori were taught literacy in their own language. By these avenues, Watkin diffused among his hearers the Christian teachings which encouraged peaceful conduct and moderation over violence and excesses which proved detrimental to the wellbeing of the community. Through more direct interventions, Watkin helped to defend young and lowly members of society from violence intended or practiced against them. This diffusion of Christian teachings and Watkin's direct interventions encouraged peace within the community. Secondly, missionaries aimed to foster peace amidst times of war by assuming the role of mediators and encouraging chiefs to adopt Christianity, by which means peaceable sentiments could be fostered within their tribe. By visiting each area of his circuit and organising church gatherings, Watkin helped to facilitate peace within and between tribes, as Wesleyan Māori from various areas assembled to participate in church activities where amiable sentiments were fostered. This thesis proposes that by these various avenues, the Reverend James Watkin contributed to the fostering of peace in the community and in times of war. 


\section{Acknowledgements}

Thank you sincerely to my supervisor Arini Loader for reviewing drafts, discussing ideas and providing valuable advice through the process of writing this thesis. Thanks also to Jim McAloon for initial help and first highlighting James Watkin's journal. Appreciation to the Methodist Church of New Zealand Archivist Jo Smith at Christchurch and staff at the Hocken Collections at Dunedin and the Alexander Turnbull Library at Wellington for assistance received. Acknowledgements also to the Joint Research Committee for awarding a grant, which facilitated a trip to Dunedin to access key sources relating to James Watkin's work at Otago and in New Zealand; this also made it possible to visit Waikouaiti Bay at Karitāne. Thanks to the HIST591 seminar class for providing useful feedback on the thesis which was taken into account. Thanks to my family for your support, without which this research would not have been possible, and to my mother Leimaka for your encouragement. Above all, I offer gratitude to the omnipotent God through Christ Jesus for enabling the completion of this work.

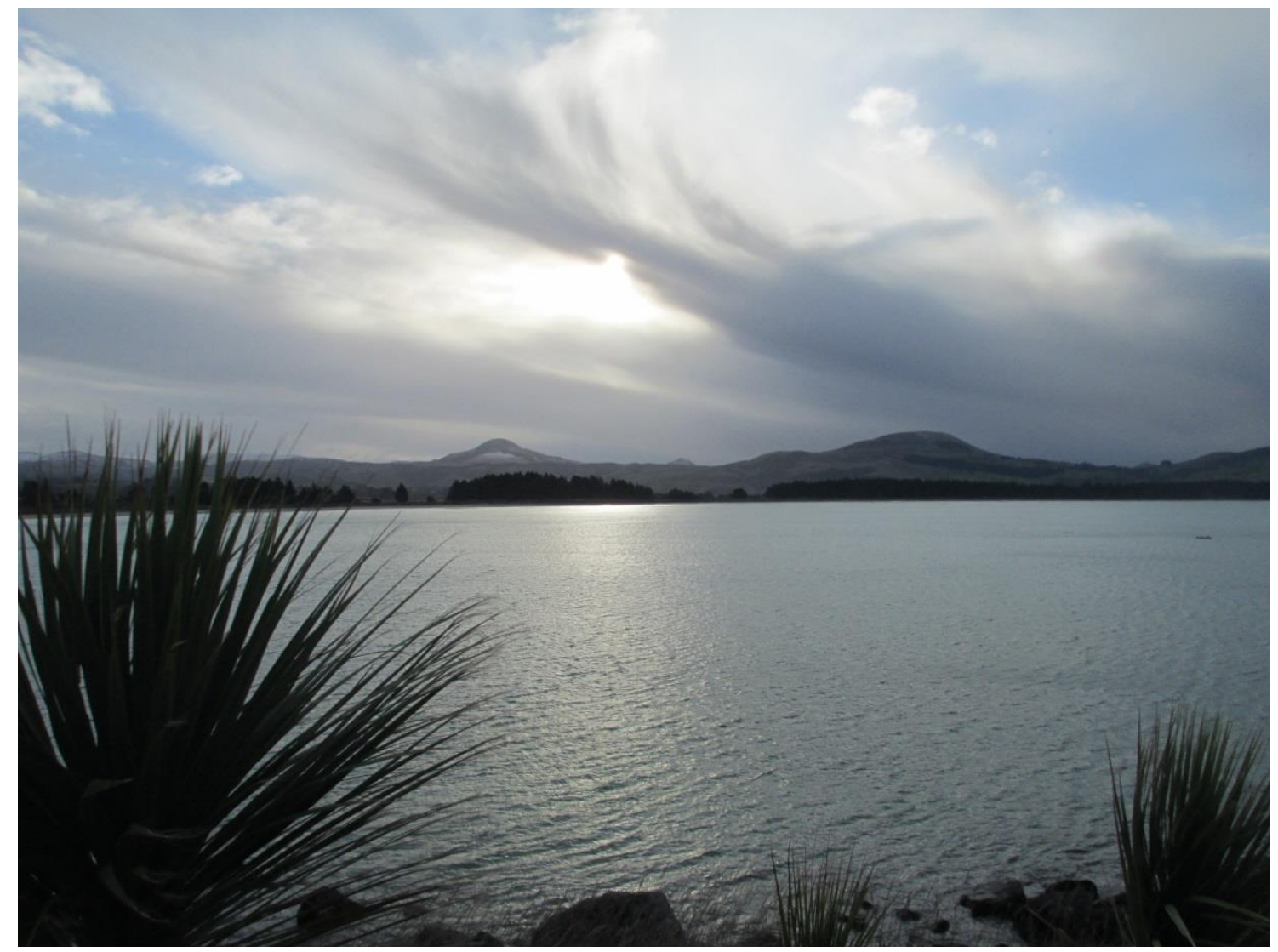

Waikouaiti Bay with the distant Mount Watkin/Hikaroroa to the centre left, 2015. 


\section{Contents}

Abstract $\quad$ i

Acknowledgements

List of Abbreviations \& Glossary of Māori terms iv

Introduction 1

James Watkin's journal and contemporary sources 4

$\begin{array}{lr}\text { Historiography on James Watkin } & 8\end{array}$

$\begin{array}{ll}\text { Missionary movement } & 13\end{array}$

$\begin{array}{ll}\text { Methodism in the South Pacific } & 16\end{array}$

Missionary beginnings in New Zealand $\quad 19$

Early nineteenth-century encounters in the southern South Island 21

$\begin{array}{ll}\text { Voyage to Karitāne } & 24\end{array}$

Chapter One: Fostering peace in the local community 27

$\begin{array}{ll}\text { Communicating the gospel through preaching } & 27\end{array}$

Furthering the communication of the gospel through schools 48

Continuation of the mission work at Wellington 62

Instances of direct intervention $\quad 66$

Chapter Two: Fostering peace in times of war 72

$\begin{array}{ll}\text { Māori population decreases } & 72\end{array}$

$\begin{array}{ll}\text { Missionary mediation } & 78\end{array}$

$\begin{array}{ll}\text { Church gatherings } & 83\end{array}$

$\begin{array}{lr}\text { Conclusion } & 89\end{array}$

James Watkin's later years 93

Bibliography $\quad 96$ 


\section{List of Abbreviations}

CMS Church Missionary Society

KJV King James Version Bible

LMS London Missionary Society

SPG Society for the Propagation of the Gospel in Foreign Parts

WMS Wesleyan Methodist Missionary Society

\section{Glossary of Māori terms}

atua - $\operatorname{god}(\mathrm{s})$

haka - (noun) vigorous posture dance with chanting, ceremonial Māori war dance

hapū - kinship group, clan, tribe, subtribe

hui - (noun) gathering, meeting, assembly, conference

iwi - tribe, bone, people of related descent

kāika/ kāinga - home village (unfortified), settlement, habitation

mana - prestige, authority, control, power

muru - plunder governed by Māori custom as compensation/ retribution for an offence

Ngā, Kāi/ Ngāi, Kāti/ Ngāti - prefix to tribal, iwi or hapū names

pā - fortified village

pounamu - greenstone, nephrite, jade

rangatira - chief (male or female), noble, well-born, high ranking, esteemed

rakatirataka/ rangatiratanga - chieftainship, ownership, self-determination, sovereignty

tā moko - traditional Māori tattooing

taepo/ taipō - ghost, demon of the night, unwanted supernatural visitor

takawaenga - mediator

taonga - treasure, anything prized

tapu - sacredness, restricted, set apart

taua - war party, hostile expedition

Te Kerēme - The [Ngāi Tahu Land] Claim

tohunga - expert, priest, learned man

utu - reciprocation, payment, compensation, revenge

whaikōrero - oration, formal speech-making, address 


\section{Introduction}

In May of 1840 the Reverend James Watkin, a Wesleyan missionary from England, arrived with his wife Hannah and their five young children at Waikouaiti, now known as Karitāne, in Otago. James Watkin was thirty-four years old and had previously visited the Bay of Islands while travelling from England to begin his missionary work in Tonga, where he was stationed for six years, and then while transiting from Tonga to New South Wales, Australia, where he worked for more than two and a half years. Karitāne however was Watkin's first long term encounter with New Zealand, where he was required to work as a pioneer; he became the first missionary to reside in the South Island and established the first mission station there. Watkin remained at Karitāne for four years before shifting to Wellington in mid-1844, where he ministered until returning to New South Wales in 1855. This thesis explores how the Christianity advocated by James Watkin facilitated the fostering of peace within the community and in times of warfare while he was stationed in New Zealand. The two types of peace focused on, which the missionary encouraged, were moral peace and physical peace in contrast to violence. Community here relates to those living nearby the mission station or circuit, including those attending the Wesleyan church services and mission schools. Warfare relates to physical combat between iwi (tribes) or between foreigners and Māori, whether it had already occurred, begun, or was at serious risk of taking place. The need for moral peace was underlined by the somewhat lawless state within which New Zealand had been, particularly prior to annexation by Britain in 1840, which took place with the intention of regulating interactions between foreigners and Māori and consequently minimising conflict. Residues of the previous order however remained when Watkin arrived in the South Island and government officers were still distant from Otago. The need for physical peace, instead of continuing or commencing warfare, was underlined by decreases in the Kāi Tahu population. By the 1840s, Māori from the Kāi Tahu iwi residing in the South Island had been recently afflicted by wars against Ngāti Toa Rangatira Te Rauparaha and from diseases introduced by Europeans. In the North Island, Māori were likewise affected by inter-tribal warfare and newly introduced diseases.

This thesis mainly considers how James Watkin's work in New Zealand helped to foster physical peace and moral peace. Peace is often considered in the context of International Relations and can be difficult to define. Oliver Richmond wrote that: 'Peace is rarely 
conceptualised, even by those who often allude to it. Not only has it rarely been addressed in detail as a concept, the theorisation of peace is normally hidden away in debates about responding to war and conflict. ${ }^{, 1}$ Therefore peace is often necessarily defined by what it contrasts with. Richmond noted that the process of defining conflict and peace is political and therefore subjective, while questions must be asked about factors such as what peace is and why, who creates and promotes it, and who peace is for. ${ }^{2}$ Where the peace referred to in this thesis relates to physical peace, this stands in contrast to physical violence, including the beginnings of what could lead to that and symptoms associated with it. This can relate to violence that occurs between or against individuals as well as between groups. Where moral peace is implied, it stands in contrast with immoral behaviours or factors likely to result in such. Those immoral behaviours could tie into unlawfulness, in terms of the British law and often relating to European actors, whether they were perpetrators or victims of the crime. It also relates to Biblical law, with immoral behaviours therefore being identified as such in the Bible and consequently influencing missionary and Christian opinions. There was also a third way in which missionaries fostered peace, by helping Māori to peacefully transition into the changing world that was resulting from increased contact with Europeans. By teaching literacy, the mission equipped Māori with skills that would allow them to effectively interact with foreigners and the government on a written platform. Mission families taught Māori new skills, for example females were taught about matters such as hygiene, child care and cooking, and this also helped them to become acquainted with European modes of conduct and the reasoning behind it, just as foreigners were increasingly beginning to migrate into the country. Most essentially the missions instructed in Christianity, which enabled Māori to understand the religious worldview that many of the immigrants identified with and which had played a fundamental role in the British society from which most of the settlers originated.

The Biblical teachings themselves, advanced by the Wesleyan missionary, largely encouraged peace. A key Bible verse on peace, as spoken by Jesus, is Matthew 5.9: 'Blessed are the peacemakers: for they shall be called the children of God.' (King James Version). John Wesley, whose theology is followed by the Wesleyan Church, in a discourse commented that the term peace-makers in this verse implied:

\footnotetext{
${ }^{1}$ Oliver P. Richmond, The Transformation of Peace (New York: Palgrave Macmillan, 2005), p. 2.

${ }^{2}$ ibid., p. 15.
} 
those lovers of God and man, who utterly detest and abhor all strife and debate, all variance and contention: and accordingly labour with all their might, either to prevent this fire of hell from being kindled, or when it is kindled, from breaking out, or when it is broken out, from spreading any farther. They endeavour to calm the stormy spirits of men, to quiet their turbulent passions, to soften the minds of contending parties, and, if possible, reconcile them to each other. They use all innocent arts, and employ all their strength, all the talents which God has given them, as well to preserve peace, where it is, as to restore it, where it is not. ${ }^{3}$

The doctrine held by Wesleyans made it evident that they should aim to foster peace among peoples. Naturally the Rev. James Watkin was well acquainted with John Wesley's writings, in the front pages of his journal recording having read sixteen volumes of Wesley's works and his notes, among many other books and Methodist texts. ${ }^{4}$ Watkin therefore considered it part of his role as a Wesleyan missionary to promote peaceful relations in New Zealand. Drawing inspiration from John Wesley, Watkin wrote in the notes for one of his sermons: 'Religion. Is it not love? That is its essence. Has always been so. ${ }^{5}$ This evidently reflected Watkin's views on his faith, and as a minister of religion he aimed to encourage these principles of peace in his sermons and among those he instructed.

The first chapter of this thesis will consider how peace was encouraged in the community through the Biblical teachings that Watkin used, and how he was able to get these ideas dispersed by commencing and running church services and schools, and through the texts that he translated into te reo Māori. It then reviews how, through cases of more direct intervention, Watkin worked to prevent violence in the community and thereby to encourage peace. The second thesis chapter explores how the missionary contributed to the fostering of peace in times of war. During times of conflict, missionaries often assumed the role of mediators to help bring about peace between groups and Christian teachings added to traditional forms of peace making. Missionaries also organised church gatherings, which brought together Māori who had accepted the Wesleyan faith and provided them with a common ground of agreement. This introduction will first examine the practice of missionaries keeping journals, then the historiography surrounding James Watkin, before

\footnotetext{
${ }^{3}$ John Wesley, The Works of the Rev. John Wesley, Vol. 5 (New York: J. \& J. Harper, 1826), p. 244.

${ }^{4}$ James Watkin, Journal of James Watkin, Vol. 1, 1830-1839, Reference Number: fMS-254, Alexander Turnbull Library, p. 3.

${ }^{5}$ James Watkin, Sermon notes, Catalogue number: MS210, Methodist Church of New Zealand Archives.
} 
briefly in turn considering early nineteenth-century missionary developments, Watkin's activity in Tonga, missionary beginnings in New Zealand, early encounters in the southern South Island and Watkin's 1840 voyage from Sydney to Karitāne. Exploring these topics helps to paint the backdrop for Watkin's missionary work in New Zealand.

\section{James Watkin's journal and contemporary sources}

James Watkin's journal is the main primary source for this research, and a photocopy of this unedited manuscript is held in two volumes at the Alexander Turnbull Library in Wellington, while the originals are at the Mitchell library in Sydney. The first volume contains entries from August 1830 to August 1839 covering James Watkin's voyage from England to Tonga with his wife Hannah, the six years he spent stationed in Tonga, where four children were born to them, then in Sydney from September 1837 where their fifth child was born. ${ }^{6}$ Volume two of James Watkin's journal has entries from 1 May 1840 to 1882, four years before he died at the age of eighty. ${ }^{7}$ This second volume will be the most heavily drawn on source, as it covers his voyage to and time at Karitāne from 1840 to 1844 and at Wellington between 1844 and 1847. There is an unexplained omission in entries after 8 November 1847 until May 1855, at which point entries resume from Australia where Watkin worked and lived for the rest of his life. The two photocopied volumes consist of 628 pages from James Watkin's journals altogether, of which eighty-eight pages cover his voyage to and time stationed in New Zealand.

In Watkin's time, the location of his first mission station in New Zealand was known as Waikouaiti, after the Waikouaiti River which it is located by the mouth of, however it is now called Karitāne. There are different explanations behind the name Karitāne; one is that the Wesleyan chief Rawiri Te Maire named it after Watkin's successor the Reverend Creed (Kariti), with Karitāne therefore meaning 'the man Creed'. Alternatively it may mean 'Bruised Man' after an incident that occurred during Taoka's siege of Te Wera's pā. ${ }^{8}$ M. A. R. Pratt however contended that the word 'tāne' really means 'the male' and he therefore did

\footnotetext{
${ }^{6}$ Watkin, Journal Vol. 1.

${ }^{7}$ James Watkin, Journal of James Watkin, Vol. 2, 1840-1882, Reference Number: fMS-255, Alexander Turnbull Library.

${ }^{8}$ Thomas A. Pybus, Maori and Missionary: Early Christian Missions in the South Island of New Zealand (Wellington: Reed Publishing, 1954), p. 9.
} 
not believe that the combination of words 'Kariti-tāne' signified 'the man Creed'. ${ }^{9}$ The present-day town of Waikouaiti, nearby Karitāne, was previously called Hawkesbury. ${ }^{10}$ Therefore although Watkin and various sources refer to his location as Waikouaiti, this thesis will refer to it by the settlement's present name of Karitāne. Additionally, this text has attempted to include macrons on Māori words where the placing of them has been identified. In his journal Watkin mentioned Otako, Otakou and Otago, often meaning the Ōtākou area; Ōtākou generally referred to the Otago Peninsula, although today it is the name of a settlement located on the eastern end of it. ${ }^{11}$ On 22 June 1848, the New Zealand Company's settlement officially adopted the name Otago which accurately reflected the southern Māori sounding of the " $k$ " in "Ōtākou". 12

James Watkin's initial purpose in journaling was to have a record of his work, from which he could every few months send back extracts to the Wesleyan Methodist Missionary Society (WMS) Secretaries in London. Missionaries in nineteenth-century New Zealand commonly kept journals to document the work that they were accomplishing and many of these are held in archives across the country. They vary in length and James Watkin's journal is particularly useful as it spans his entire missionary career over the three countries of Tonga, New Zealand and Australia; he wrote his first entry aged twenty-four and his last when seventy-six years old. While missionary men sent out by the WMS had to render an account of their activities to the general secretaries of the society, this does not appear to have been required from their wives. Descendants were more likely to preserve the written records kept by missionary men than women, and they may have kept journals for differing reasons. ${ }^{13}$ For example Eliza White, married to the Wesleyan missionary William White, kept a journal at the request of her parents in England who wished to know how their young daughter's life was progressing

\footnotetext{
${ }^{9}$ M. A. Rugby Pratt, The Pioneering Days of Southern Maoriland (London: Epworth Press, 1932), p. 23.

${ }^{10}$ Pybus, Maori and Missionary, p. 9.

${ }^{11}$ Thomas A. Pybus, Otakou, A Story of Far-off Days (Auckland: Wesley Historical Society of New Zealand, 1941), p. 2.

${ }^{12}$ Harry C. Evison, Te Wai Pounamu - The Greenstone Island: A History of the Southern Maori during the European Colonization of New Zealand (Wellington and Christchurch: Aoraki Press, 1993), p. 219.

${ }^{13}$ Sandra Coney, 'Eliza White' in Charlotte Macdonald, Merimeri Penfold and Bridget Williams (eds.), The Book of New Zealand Women: Ko Kui Ma Te Kaupapa (Wellington: Bridget Williams Books Limited, 1991), p. 722.
} 
in New Zealand. ${ }^{14}$ She encouraged her parents to share parts of her journal with friends to support the mission cause. ${ }^{15}$ Missionary men could likewise write with the intent of encouraging support for the missionary work back in England, although this may have been done more in printed publications. Peter Sherlock notes that missionary letters, magazines and minutes could be written with the missionaries' supporters and superiors in mind. ${ }^{16}$ While missionaries could record more of their personal thoughts in journals, extracts from these were commonly sent back to the WMS, and many times James Watkin was just as expressive in his letters to the WMS as in his journal entries.

Watkin did not always enjoy journaling, writing at Karitāne on 21 February 1844: 'the monotony of my life, my circumscribed sphere, and my painful feelings renders journalizing anything but pleasant to me. ${ }^{17}$ While journaling had the potential to serve as a type of release, for Watkin it could at times be repetitive and bring to mind the challenges that he was facing. Nevertheless, Watkin confided more in his journal when living amidst the relative isolation of Karitāne than he did later at Wellington. Watkin filled nearly seventy pages of his journal while at Karitāne for just over four years, compared to writing in just over fifteen pages during his ten years and nine months at Wellington. In some cases it was not practical to journal, and in Australia in later life Watkin noted that his journal was a big book which he would not be carrying with him on voyages. ${ }^{18}$ For this reason journal entries were sometimes written in retrospect after he returned from journeys. In 1868 at the age of sixty-two, James Watkin commented: 'I make entries from habit I suppose. The entries I make are uninteresting to myself, must be more so to others if others should ever see them. I suppose I shall continue the practice, until my hand forgets its poor cunning ${ }^{19}$ Five years later Watkin again wrote that he journaled out of habit, having started forty-three years before, which is

\footnotetext{
${ }^{14}$ Frances Porter, Transcription of Eliza White Journals 16 September 1829-28 April 1836, Reference Number: MSDL-0123, Alexander Turnbull Library, 2004, 3 April 1833, p. 103.

15 ibid., 26 January 1836, p. 173.

${ }^{16}$ Peter Sherlock, 'Missions, Colonialism and the Politics of Agency' in Barry, Amanda et al. (eds.), Evangelists of Empire?: Missionaries in Colonial History (Melbourne: eScholarship Research Centre, 2008), p. 15.

${ }^{17}$ Watkin, Journal Vol. 2, 21 February 1844, p. 363.

18 ibid., 5 April 1869, p. 562.

19 ibid., 23 May 1868, p. 555.
} 
when he first left England for the mission fields. ${ }^{20}$ While Watkin began journaling mostly to document his endeavours for the WMS, over time it became a custom and a personal historical record.

Letters sent by James Watkin are another key primary source for learning more about his time in Aotearoa. Watkin sent letters from New Zealand to the Wesleyan Methodist Missionary Society in London, which can be accessed on microfilm as part of the Methodist Missionary Society Records held at the Hocken Collections in Dunedin. ${ }^{21}$ These reels also provide access to letters that other Wesleyan missionaries sent to the WMS and for this research some of the letters sent by the Revs. Samuel Ironside and Charles Creed were examined, as Creed succeeded Watkin at Otago while Ironside worked alongside him at Wellington and they therefore commented on matters relevant to Watkin's work. Watkin's letters to the WMS were often accompanied by several pages of recent extracts from his journal and they shed greater light on the journal entries. Watkin occasionally added extra details, not found in the original journal, to some of the journal extracts he sent to the WMS. Extracts of letters that Watkin sent from Karitāne to Samuel Ironside and a transcript of letters that Watkin sent to the Rev. James Buller at Kaipara between 1840 and 1844 can be accessed through the Methodist Church of New Zealand Archives. ${ }^{22}$ Viewing letters that Watkin sent to other Wesleyans is useful for the extra details they provide, adding to the information written in his journal. In his letters Watkin was writing to inform others and therefore he wrote with greater clarity, particularly if he discussed an event that he did not assume the reader had prior knowledge of.

Another contemporary source of information is Edward Shortland's text The Southern Districts of New Zealand; A Journal, with Passing Notices of the Customs of the Aborigines, which details Shortland's visit to the South Island from August 1843 to February $1844 .^{23}$

\footnotetext{
${ }^{20}$ ibid., 9 August 1873, p. 594.

${ }^{21}$ Methodist Missionary Society Records, Reference Number: Micro-163, Reels 20-25, Hocken Collections, University of Otago.

${ }^{22}$ Paul W. Fairclough, Copy of Extracts from letters to Rev Samuel Ironside, Cloudy Bay \& Wellington, from Rev James Watkin, Waikouaiti 1 June 1841- 22 April 1844, Catalogue No. MS208, Methodist Church of New Zealand Archives, 1902; James Watkin, Letters to James Buller, Catalogue No. MS207, Methodist Church of New Zealand Archives, 1840-1844.

${ }^{23}$ Edward Shortland, The Southern Districts of New Zealand; A Journal, with Passing Notices of the Customs of the Aborigines (Christchurch: Caper Press, 1974).
} 
Shortland travelled as a newly appointed Protector of the Aborigines for the Colonial Government of New Zealand and to act as an interpreter for Colonel Godfrey, the Commissioner assigned to examine land claims south of Cook Strait. Shortland met James Watkin when he went to Karitāne in October 1843 and mentioned him several times in this text, which serves as an alternative source of information for activities being carried out in the South Island concerning Māori and Europeans during the early 1840s. It is useful to compare Watkin and Shortland's journal entries, in order to see alternative perspectives on the various issues mentioned. Shortland commented on matters including travelling in the South Island, whaling stations, European land claims, missionary activity, and Māori population changes and worldview. Another contemporary source is the account given by Dr David Monro, who visited Karitāne with a group of surveyors in $1844 .{ }^{24}$ His account briefly described the area, its inhabitants, and James Watkin's mission work there at the time.

\section{Historiography on James Watkin}

This section will provide an overview of key texts, ranging from the late nineteenth century to the present day, that have been written on James Watkin or that have discussed his work. An early secondary source is the eight page article 'A Biography of James Watkin: a pioneer missionary in the Friendly Islands and in New Zealand, ex-president of the Australian Conference' by Samuel Ironside, which appeared in the Wesleyan-Methodist Magazine in October $1891 .^{25}$ This biography remains a key source of information, providing details on Watkin's early life and summarising his work in Tonga, New Zealand and Australia, being particularly useful as it is informed by Ironside's personal knowledge of Watkin, who he worked alongside at Wellington and later in New South Wales. During the first half of the twentieth century, many of the texts written on James Watkin were by Methodist ministers Major Albert Rugby Pratt and Thomas Arthur Pybus. They both wrote many articles relating to the topic for newspapers and Methodist publications. Pratt was also a historian and one of his articles 'James Watkin: Otago's Religious Pioneer' was published in an Otago newspaper The Evening Star in 1928, outlining Watkin's missionary work in Tonga, Sydney, Karitāne

\footnotetext{
${ }^{24}$ David Monro, 'Notes of a Journey through a part of the Middle Island of New Zealand' in Hocken, Thomas M., Contributions to the Early History of New Zealand (Settlement of Otago), (London: Sampson Low, Marston and Company, 1898), p. 241.

${ }^{25}$ Samuel Ironside, 'A Biography of James Watkin: A pioneer Missionary in the Friendly Islands and in New Zealand, Ex-President of the Australian Conference', The Wesleyan-Methodist Magazine, October 1891, pp. 730-737.
} 
and Wellington. ${ }^{26}$ Pratt later selected, transcribed and annotated many of James Watkin's journal entries from Karitāne, which featured in a Canterbury newspaper The Press as a weekly special article from June to September $1931 .{ }^{27}$ Before this, parts of Watkin's journal had only been published in Robert McNab's 1913 book The Old Whaling Days: A History of Southern New Zealand from 1830 to 1840 and a small pamphlet by the Rev. Paul W.

Fairclough. ${ }^{28}$ Pratt's 1932 book The Pioneering Days of Southern Maoriland provides one of the most detailed considerations of Watkin's work at Karitāne and was also informed by Pratt's personal experiences; for example, he had heard missionary stories directly from the Rev. Samuel Ironside and James Watkin's sons Edwin and Jabez. ${ }^{29}$

More was written on James Watkin around 1940, marking one hundred years since the signing of the Treaty of Waitangi and the commencement of the first South Island mission station under Watkin. As part of the South Island Centenary Commemorations, Thomas Arthur Pybus wrote several booklets describing the early missionaries at Karitāne. 'Otakou and the First Christian Mission: A Brief Statement' covered the establishment of the Karitāne mission station, while the booklet 'Heroic Pioneer Workers' recorded the labours of James Watkin and his successors the Revs. Charles Creed, William Kirk and George Stannard. ${ }^{30}$ Pybus also transcribed and published excerpts from a letter written by James Watkin in New Zealand to his cousin the Reverend Joseph Entwistle, which provides Watkin's view on how he came to be appointed to Karitāne, his early impressions of the South Island and his mission work. ${ }^{31}$ The 18 May 1940 edition of The New Zealand Methodist Times was printed closest to the date when Watkin had arrived at Karitāne on 16 May one hundred years before. It consequently carried this theme, containing an article by Pybus detailing James Watkin's

\footnotetext{
${ }^{26}$ M. A. Rugby Pratt, 'JAMES WATKIN: Otago’s Religious Pioneer', The Evening Star, 16 May 1928, Alexander Turnbull Library.

${ }^{27}$ Major Albert Rugby Pratt, 'Ninety Years Ago: Diary of the Rev. James Watkin', The Press, 13 June - 19 September 1931, Alexander Turnbull Library.

${ }^{28}$ ibid., 13 June 1931, p. 1.

${ }^{29}$ Pratt, The Pioneering Days, pp. 15-16.

${ }^{30}$ Thomas A. Pybus, 'Otakou and the First Christian Mission: A Brief Statement' (Dunedin: Otago Daily Times print, 1940), Alexander Turnbull Library; Thomas A. Pybus, 'Heroic Pioneer Workers' (Dunedin: Otago Daily Times print, 1940), Alexander Turnbull Library.

${ }^{31}$ Thomas A. Pybus, 'Rev. James Watkin: An Unpublished Letter', Otago Daily Times, 2 June 1939, Alexander Turnbull Library.
} 
work at Ōtākou and articles by Pratt on Watkin's pioneer work in the South Island, on Charles Creed who was appointed to Otago after Watkin, on Samuel Ironside who established a mission at Cloudy Bay in the South Island in December 1840, and on the Methodist activity in Canterbury around the mid-nineteenth century. ${ }^{32}$ In 1941, Pybus' text Otakou, A Story of Far-Off Days was published by the New Zealand branch of the Wesley Historical Society and describes the early history of Ōtākou, James Watkin's work at the Karitāne mission station and that of his successors. It also describes the establishment of the Centennial church at Ōtākou, which Pybus helped to effect, in commemoration of one hundred years since the signing of Te Tiriti o Waitangi and the first South Island mission. ${ }^{33}$ Pybus' 1954 book Maori and Missionary: Early Christian Missions in the South Island of New Zealand considers Watkin's time at Karitāne in detail, examining Watkin's journal entries and letters and following the work of his successors. ${ }^{34}$

James Watkin's mission work at Karitāne was also examined in Margaret E. Major's 1964 Master's thesis 'Christian Missions in the South Island in the 1840 's' ${ }^{35}$ Major suggested that early South Island missionaries faced a harder task as they arrived after other Europeans had already resided there and influenced Māori, whereas in the North Island missionaries arrived earlier and more in time with other residents. ${ }^{36}$ The role of missionaries in peacekeeping is considered in Samuel Ritchie's 2013 doctoral thesis “'Of Red War and Little Else': European Responses to Indigenous Violence in the Tasman World, c.1769-1850s'. ${ }^{37}$ Ritchie notes that missionaries did play a central role in the even distribution of peace but this was most

\footnotetext{
32 Thomas A. Pybus, 'The Rev. James Watkin and the Otakou Mission', The New Zealand Methodist Times, 18 May 1940, pp. 22-23; Major Albert Rugby Pratt, 'The Rev. James Watkin: The Pioneer of Christianity in the South Island', The New Zealand Methodist Times, 18 May 1940, p. 26; Major Albert Rugby Pratt, 'Rev. Charles Creed and Early Otago', The New Zealand Methodist Times, 18 May 1940, pp. 28-29; Major Albert Rugby Pratt, 'Rev. Samuel Ironside: A Star of the Maoriland Morning', The New Zealand Methodist Times, 18 May 1940, pp. 24-25; Major Albert Rugby Pratt, 'Early Methodism in Canterbury', The New Zealand Methodist Times, 18 May 1940, p. 27.

${ }^{33}$ Pybus, Otakou, A Story of Far-off Days.

${ }^{34}$ Pybus, Maori and Missionary.

${ }^{35}$ Margaret E. Major, 'Christian Missions in the South Island in the 1840's' (M. A. thesis, University of Canterbury, 1964).

${ }^{36}$ ibid., pp. v, 31, 113.

${ }^{37}$ Samuel G. G. Ritchie, “'Of Red War and Little Else': European Responses to Indigenous Violence in the Tasman World, c.1769-1850s' (Doctoral thesis, Victoria University of Wellington, 2013).
} 
effective when Māori had requested their intervention. ${ }^{38}$ Hazel Petrie's 2015 book Outcasts of the Gods? The Struggle over Slavery in Māori New Zealand also briefly considers the role of missionaries as peacemakers, noting that missionary mediation provided a way for Māori to declare peace without losing mana (prestige). ${ }^{39}$ Presbyterian minister Roy Belmer's 1979 text James Watkin: Pioneer Missionary, which is just under forty pages in length, outlines Watkin's appointment to Tonga and then his work, activities and challenges at Karitāne. ${ }^{40}$ Belmer suggested that Watkin was instrumental in making white settlement possible in the South Island in a peaceful manner, in contrast to the Māori wars in the North Island. ${ }^{41}$ The 1982 book Samuel Ironside in New Zealand 1839-1858 by Wesley A. Chambers is particularly useful in chapter eight where it describes the Wesleyan mission work occurring at Wellington from 1843 to 1849 , covering Watkin's first few years there, among its sources referencing James Watkin's journal entries and letters, along with Ironside's letters and contemporary newspaper articles. ${ }^{42}$ Watkin worked with Ironside at Wellington and the text usefully details conflicts occurring between some Māori factions and European troops at the time, collaborations among ministers in Wellington, and the earthquake that struck Wellington in October 1848.

Most of the secondary texts written about James Watkin have centred on his four years at Karitāne, despite the fact that he spent more years working at Wellington, Tonga and New South Wales individually. This is likely because in these latter three locations Watkin added to the efforts of other missionaries who went before him, whereas at Karitāne he had to establish the mission from scratch without a predecessor, laying the foundation for future missionary efforts. He was the first missionary to reside in the South Island, where missionaries were scarce when the Watkins arrived at Karitāne in May 1840. James Watkin's journal entries suggest that although he faced trials at all of his mission stations, Karitāne proved the greatest struggle for him. There were a combination of reasons for this, including

\footnotetext{
38 ibid., pp. 167-168, 174-176, 180, 185-186.

${ }^{39}$ Hazel Petrie, Outcasts of the Gods? The Struggle over Slavery in Māori New Zealand (Auckland: Auckland University Press, 2015), p. 253.

${ }^{40}$ Roy Belmer, James Watkin: Pioneer Missionary (Auckland: Wesley Historical Society of New Zealand, 1979).

${ }^{41}$ ibid., pp. 24, 38.

${ }^{42}$ Wesley A. Chambers, Samuel Ironside in New Zealand 1839-1858 (Auckland: Ray Richards Publisher, 1982).
} 
the isolation of the station and prolonged delays in receiving mail, worries about his children's education and, as Pybus noted, generally suffering from 'neurasthenia and depression of spirit' as well as physical weakness. ${ }^{43}$ Yet the difficulty of the task was a reflection of its significance and in history it is James Watkin's work at Karitāne that has received the greatest recognition.

James Watkin has commonly featured in texts covering Otago, Wesleyan or missionary history in New Zealand. His time at Karitāne is described in Erik Olssen's 1984 book A History of Otago. ${ }^{44}$ The context of Watkin's South Island work is also recorded in Harry Evison's 1993 book Te Wai Pounamu The Greenstone Island: A History of the Southern Maori during the European Colonization of New Zealand, which covers Ngāi Tahu history including early missionary activity, encounters with Europeans, the wars with Te Rauparaha, the Treaty of Waitangi and land sales in the South Island. ${ }^{45}$ Atholl Anderson's 1998 book The Welcome of Strangers: An ethnohistory of Southern Maori A. D. 1650-1850 details the history of Māori in the South Island, in some parts drawing on Watkin's journal entries and also detailing the background within which Watkin's labours among Māori at Karitāne took place. ${ }^{46}$ Michael J. Stevens' 2010 article 'Kāi Tahu Writing and Cross-Cultural Communication' mentions James Watkin's role in teaching literacy to Kāi Tahu people when stationed at Karitāne. ${ }^{47}$ Tony Ballantyne's 2011 article 'Paper, Pen, and Print: The Transformation of the Kai Tahu Knowledge Order' notes the role of Watkin's mission in bringing texts and paper to Kāi Tahu communities. ${ }^{48}$ While several key sources on James Watkin's time in New Zealand have been noted, this is not a complete list of all the texts written of him. Watkin's work continues to be mentioned because his journal remains a valuable and unique source of insight into life as a missionary and in New Zealand in the 1840 s.

\footnotetext{
${ }^{43}$ Pybus, 'Heroic Pioneer Workers', p. 2.

${ }^{44}$ Erik Olssen, A History of Otago (Dunedin: John McIndoe, 1984).

${ }^{45}$ Evison, Te Wai Pounamu.

${ }^{46}$ Atholl Anderson, The Welcome of Strangers: An ethnohistory of Maori A.D. 1650-1850 (Dunedin: University of Otago Press, 1998).

${ }^{47}$ Michael J. Stevens, 'Kāi Tahu Writing and Cross-Cultural Communication', Journal of New Zealand Literature, No. 28, Part 2: Special Issue: Cultures of Print in Colonial New Zealand, 2010, pp. 130-157.

${ }^{48}$ Tony Ballantyne, 'Paper, Pen, and Print: The Transformation of the Kai Tahu Knowledge Order', Comparative Studies in Society and History, Vol. 53, no. 2, 2011, p. 243.
} 
This research intends to add to what has been written on James Watkin by focusing on how his work promoted moral and physical peace in the areas where he was stationed. Pratt, Pybus and Belmer have mentioned Watkin's role in fostering peace, particularly in relation to the peaceful sale of land at Otago, however they have not centred their writing on this. James Watkin's role as a peace maker has not been expounded upon, while his work as a pioneer has more commonly received emphasis. This writing intends to build on the idea that Watkin helped foster peace and to consider how this was achieved by spreading the gospel and Christian teachings conducive to peace, by directly intervening to discourage violence and conduct that was disruptive to the community, and by providing the conditions within which Wesleyan Māori could unite under a shared faith.

\section{Missionary movement}

It is beneficial to briefly consider the early British missionary societies, in order to understand the background within which James Watkin became a missionary and commenced his work in the South Pacific. In June 1701 the Society for the Propagation of the Gospel in Foreign Parts (SPG) was established to minister to the British colonies. From 1736 to 1738 John Wesley, later a co-founder of Methodism, worked as an SPG missionary in the British colony of Georgia in North America. The earliest Methodist missionary activities however were largely reliant on individual initiatives. ${ }^{49}$ In the late eighteenth century many British Protestant denominations experienced revival, reacting against a perceived moral crisis in the wake of industrial and political change. ${ }^{50}$ They sought to promote Christianity in Britain and in the non-European world and new missionary societies arose in the 1790s, including the Baptist Missionary Society, the London Missionary Society (LMS), the Edinburgh and Glasgow Missionary Societies and what was later known as the Church Missionary Society (CMS). ${ }^{51}$ The Religious Tract Society was founded in 1799, the British and Foreign Bible Society in 1804 and the Wesleyan Methodist Missionary Society in 1813; previously the Wesleyans had supported the LMS which was originally a non-denominational

\footnotetext{
${ }^{49}$ Andrew Porter, Religion versus empire? British Protestant missionaries and overseas expansion, 1700-1914 (Manchester and New York: Manchester University Press, 2004), pp. 17, 30, 31.

${ }^{50}$ Timothy Parsons, The British Imperial Century, 1815-1914: A World History Perspective (Oxford: Rowman \& Littlefield, 1999), p. 19.

${ }^{51}$ ibid., p. 20; Porter, Religion versus empire?, p. 40.
} 
organisation. ${ }^{52}$ Methodists and the SPG focused their early missionary efforts on British colonies in North America and the West Indies, the LMS on the Pacific and Cape Colony, Baptists on India and the CMS on Africa and the East. ${ }^{53}$ One factor encouraging missionary activity was the increasingly favoured Christian doctrine of justification by faith, rather than Calvinistic beliefs in the predestination of the elect which had previously deterred mission work. ${ }^{54}$ John Wesley held to justification by faith, believing that Christ had died for the sins of all, so that any who had faith in him could be saved. ${ }^{55}$ This meant that non-Europeans could likewise attain unto salvation through faith, rather than redemption being the privilege of the elect. There was therefore a need for foreign missions, as foreign peoples would first need to learn about Christ in order to have faith in him. By 1830 most of the missionary societies had increased their subscriptions, thus increasing their incomes, and had better prospects for recruiting missionaries. ${ }^{56}$

James Watkin was born in Manchester, England, on 29 September 1805 and was of Welsh descent. ${ }^{57} \mathrm{He}$ credited the good example of his mother Elizabeth (Betty), née Hoyle, for his early decision to come to Christ, although she died in 1825 shortly before he reached the age of twenty. ${ }^{58}$ Samuel Ironside recalled of Watkin's home town: 'Manchester was favoured with the best Preachers of our Church, at whose feet he [James Watkin] sat with delight and profit. I have often heard him speak with enthusiasm of Jabez Bunting, Watson, Newton, Lessey and others. Many times have we revived our recollections of these men of renown.

\footnotetext{
${ }^{52}$ Hilary M. Carey, God's Empire: Religion and Colonialism in the British World, c.1801-1908 (Cambridge: Cambridge University Press, 2011), p. 54; Susan Thorne, Congregational Missions and the Making of an Imperial Culture in Nineteenth-Century England (Stanford: Stanford University Press, 1999), p. 24.

${ }^{53}$ Porter, Religion versus empire?, p. 52.

${ }^{54}$ ibid., pp. 32, 28.

${ }^{55}$ J. M. R. Owens, The Wesleyan Missionaries to New Zealand Before 1840 (Tauranga: Don Kale Printing Co. Ltd, 1982), p. 9.

${ }^{56}$ Porter, Religion versus empire?, p. 91.

${ }^{57}$ Pybus, Maori and Missionary, p. 1.

${ }^{58}$ Ironside, p. 730; People Information files, Rev James Watkin, Methodist Church of New Zealand Archives. When James Watkin turned seventy in 1875 he noted in his journal that his mother had been dead for over fifty years. See Watkin, Journal Vol. 2, 29 September 1875, p. 598. The Methodist Church of New Zealand Archives' (MCNZA) information file on James Watkin states that his father died circa 1810 around the age of thirty-two, when James Watkin would have been around four or five years old and his mother around the age of thirty. She may have subsequently remarried while her son was still at a young age, as in an 1841 journal entry James Watkin recorded having just received news of his father's death from a letter sent to him two years and one month before, which would suggest that he had a stepfather who died in early 1839. See Watkin, Journal Vol. 2, 29 March 1841, p. 321.
} 
'There were giants in those days', ${ }^{59}$ Jabez Bunting was a WMS secretary and President of the Wesleyan Methodist Conference four times. ${ }^{60}$ These preachers may have inspired James Watkin to seek a career in the ministry and his third-born son was named Jabez Bunting. After Watkin began preaching, a man offered to fund his university training at Oxford if he would join the ministry of the Church of England; Watkin turned down the offer, preferring to remain with the church that he had been converted in. ${ }^{61}$ Around 1826, James Watkin commenced working as a local preacher in the Oldham Street circuit in Manchester, and in 1830 he was ordained at the Sloane Terrace Church in Chelsea, London. ${ }^{62}$ Several weeks later James Watkin married Hannah Entwisle, who was born circa 1806 in Manchester, a niece of the Rev. Joseph Entwisle. ${ }^{63}$ Their marriage likely took place in preparation for departure for the mission fields, as Watkin wrote in his journal after turning twenty-five in September of 1830, that a year before he had not expected to leave his country and be married so soon. ${ }^{64}$ In December of 1829 he had also been recorded as having no matrimonial engagement. ${ }^{65}$ After one of the men appointed for the Tonga group of islands was unable to go, the Missionary Committee in London assigned James Watkin to accompany Peter Turner and William Woon to Tonga. ${ }^{66}$ On 7 August 1830, they left Gravesend in England on the Lloyds. ${ }^{67}$ Thomas Pybus noted: 'As the ship proceeded from Gravesend she passed the Royal barge, on the deck of which stood King George IV. When the King was informed that there were missionaries on board for distant lands he walked to the stern of the barge and stood with hat lifted until the ship passed out of sight. ${ }^{, 68}$ In January 1831 they reached the Bay of

\footnotetext{
${ }^{59}$ Ironside, p. 730.

${ }^{60}$ Porter, Religion versus empire?, p. 50; Watkin, Journal Vol. 2, 30 December 1844, p. 370.

${ }^{61}$ Ironside, p. 730; Pratt, 'The Rev. James Watkin: The Pioneer', p. 26.

${ }^{62}$ People Information files, Rev James Watkin, MCNZA; Pratt, The Pioneering Days, p. 57; Pybus, Maori and Missionary, p. 2.

${ }^{63}$ People Information files, Rev James Watkin, MCNZA; Pratt, 'The Rev. James Watkin: The Pioneer', p. 26; Owens, The Wesleyan Missionaries, p. 24; Ironside, p. 730. MCNZA's information file on James Watkin states that Hannah Entwisle was born in 1806, while Owens stated that she was born in 1807.

${ }^{64}$ Watkin, Journal Vol. 1, 30 September 1830, p. 23.

65 'Minutes of the Candidates Committee, 1829-41', Methodist Missionary Society Records, Reference Number: Micro-163, Reel 49, Hocken Collections, University of Otago, p. 8.

${ }^{66}$ Pratt, The Pioneering Days, pp.57-58; Ironside, pp. 730-731.

${ }^{67}$ Pratt, 'The Rev. James Watkin: The Pioneer', p. 26.

68 Pybus, 'Heroic Pioneer Workers', p. 1.
} 
Islands, where the missionaries and their families stayed for one month while the vessel went on a short whaling trip, after which they resumed their journey to Tonga. ${ }^{69}$

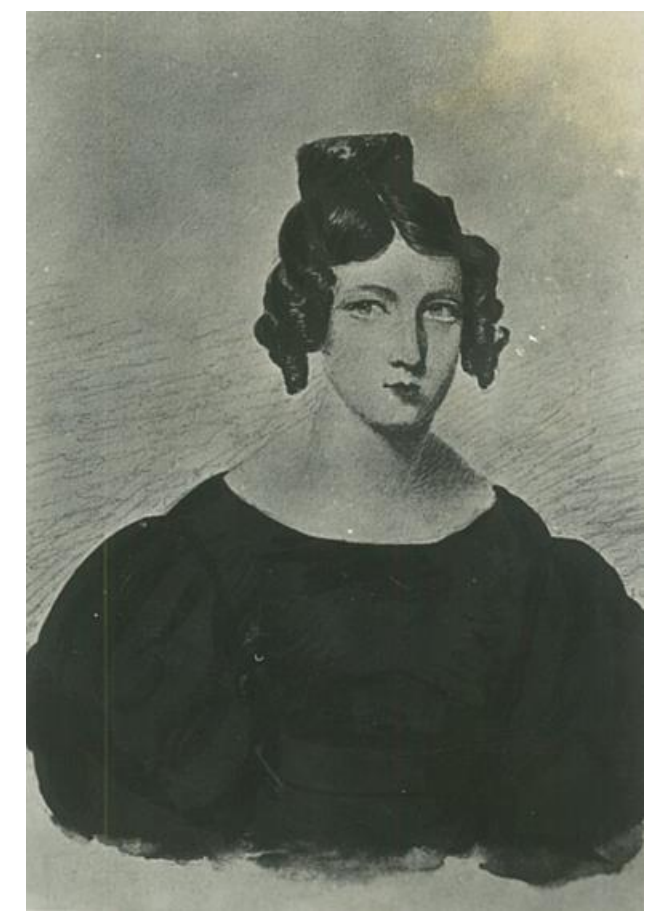

Hannah Entwisle before her marriage

Mrs Watkin, Photographs Collection, Methodist

Church of New Zealand Archives.

\section{Methodism in the South Pacific}

James Watkin's work in the South Pacific contributed to the efforts of earlier missionaries and facilitated the arrival of later ones. In 1796 the LMS sent four ordained missionaries and twenty-six other skilled persons to Tahiti; however most abandoned the project within three years and the mission withdrew from the outer islands of Tongatapu and the Marquesas to Tahiti. ${ }^{70}$ Pybus stated that escaped convicts were responsible for stirring up hostility against the missionaries, and later attempts by Wesleyan missionaries Walter Lawry and William Woon were also unsuccessful in Tonga due to opposition. ${ }^{71}$ However, by the time that James Watkin and his companions joined the mission in Tonga in 1831, John Thomas had been working there for three years, joined by William Cross, Nathaniel Turner, John Hobbs and

\footnotetext{
${ }^{69}$ Pratt, 'The Rev. James Watkin: The Pioneer', p. 26; Ironside, p. 731; Watkin, Journal Vol. 1, 17 March 1831, pp. 38-40.

${ }^{70}$ Porter, Religion versus empire?, pp. 56-57.

${ }^{71}$ Pybus, Maori and Missionary, pp. 4-5.
} 
James Stack. ${ }^{72}$ When stationed at Lifuka in Ha'apai, the central group of Tonga, James Watkin personally witnessed a revival. This had begun in Vava'u on 23 July 1834 in a service conducted by a Tongan preacher and reached Ha'apai the following month. ${ }^{73}$ By the time that Watkin left Lifuka for Nuku'alofa in March 1835, having been stationed there for three years, he reported having baptised 2,687 candidates, 938 children, and conducted 769 marriages. ${ }^{74}$ The revival boosted the number of Christians in Tonga to more than seven thousand, nearly one fifth of the population. ${ }^{75}$ The converts included George or Tāufa āhau the reigning prince of Ha'apai who later became King of Tonga. ${ }^{76}$ James Watkin's time in Tonga unfortunately ended on an anti-climax after he confessed to Hobbs that, while his wife was in Ha'apai, he had formed a deep attraction for her Tongan maid. ${ }^{77}$ As Ballantyne stated: 'Breaches of missionary monogamy were taken all the more seriously, as they were understood to contravene the bedrock of the mission's program: the missionary as exemplar and model Christian conjugal family. ${ }^{78}$ Watkin's transgression became a cause of bitter regret to him, contributing to his depression when later stationed at Karitāne, where he struggled with factors such as the isolation of the station. ${ }^{79}$ Watkin and his wife Hannah's declining health compounded their need to relocate from Tonga to another mission field. ${ }^{80}$ Yet Watkin remained earnest in his efforts to spread the gospel to indigenous peoples in Tonga and later in New Zealand.

\footnotetext{
${ }^{72}$ Ironside, p. 731.

${ }^{73}$ Watkin, Journal Vol. 1, 10 August 1834, p. 185; Sione Latukefu, 'The case of the Wesleyan Mission in Tonga', Journal de la Société des Océanistes, Vol. 25, 1969, p. 98.

${ }^{74}$ Watkin, Journal Vol. 1, 11 March 1835, p. 217.

${ }^{75}$ Evison, Te Wai Pounamu, p. 86.

${ }^{76}$ Ironside, p. 732; Pratt, The Pioneering Days, p. 59.

${ }^{77}$ Evison, Te Wai Pounamu, p. 88.

${ }^{78}$ Tony Ballantyne, Entanglements of Empire: Missionaries, Māori, and the Question of the Body (Auckland: Auckland University Press, 2015), p. 172.

${ }^{79}$ Watkin, Journal Vol. 1, 18 April 1837, p. 275; James Watkin, Letter to the General Secretaries of the Wesleyan Missionary Society, January 1841, Methodist Missionary Society Records, Reference Number: Micro-163, Reel 20, Hocken Collections, University of Otago, pp. 1-2; Pybus, 'The Rev. James Watkin and the Otakou Mission', p. 23.

${ }^{80}$ Pybus, 'Heroic Pioneer Workers', p. 1; Watkin, Journal Vol. 1, 24 April 1836, p. 262.
} 
The spread of Christianity in Tonga however was entangled in conflict. On Tongatapu, the southern island group of Tonga, some of the chiefs and priests felt that their power was threatened by Christianity and converts faced persecution. ${ }^{81}$ At the start of 1837 while Watkin was stationed on Tongatapu, opponents commenced an attack on the Christians, who consequently fought back. ${ }^{82}$ The Christian chief Tupou of Tongatapu received help from Christians on the other islands and from George Tupou I the King of Tonga. Watkin and fellow Wesleyan missionary John Hobbs attended to those wounded in the war. ${ }^{83}$ While the prospect of peace had improved by mid-April 1837, in 1840 Watkin was grieved to learn of ongoing war in Tonga. ${ }^{84}$ However, the mission work progressed and by 1853 the Tonga island groups of Vava'u, Ha'apai, the Niuas and much of Tongatapu had accepted Christianity. ${ }^{85}$ While critiquing the Wesleyan missionaries for being too extreme in their condemnation of Tongan traditions and for failing to teach the people more practical skills of economic value, Sione Latukefu noted that the missionaries promoted literacy and improved health treatment in Tonga and they ultimately: 'helped to unite the country under a monarchical system and introduced the rule of law and brought peace and order to the country. ${ }^{86}$ Tonga became a nation that largely identified with Christianity, which Watkin was able to see during a visit to the islands in later life. ${ }^{87}$

Christianity spread to Samoa initially through its links to Tonga, with a Samoan man named Saivaaia being converted during a visit to Tonga in 1828 and returning to spread the gospel at home. Official Wesleyan work in Samoa began in 1835, closed in 1839 due to the LMS asserting it as their territory, and reopened in 1857 to minister to Methodists there. ${ }^{88}$ Teachers

\footnotetext{
${ }^{81}$ T. M. I. Williment, John Hobbs 1800-1883: Wesleyan Missionary to the Ngapuhi Tribe of Northern New Zealand (Wellington: Government Printing Office, 1985), pp. 112, 110; Watkin, Journal Vol. 1, 13 November 1834, p. 212.

${ }^{82}$ Watkin, Journal Vol. 1, 11 January 1837, p. 272.

${ }^{83}$ Williment, p. 112.

${ }^{84}$ Watkin, Journal Vol. 1, 8 and 15 April 1837, p. 275; Watkin, Journal Vol. 2, 28 September 1840, p. 307.

${ }^{85}$ Latukefu, pp. 98-99.

${ }^{86}$ ibid., p. 111.

87 ‘THE LATE REV. JAS. WATKIN’, Evening Post, 5 June 1886, p. 1.

${ }^{88}$ George G. Carter, A Family Affair: A Brief Survey of New Zealand Methodism's Involvement in Mission Overseas 1822-1972 (Auckland: Wesley Historical Society of New Zealand, 1973), pp. 28-31.
} 
sent out from Tonga helped to strengthen the work in Samoa and Fiji; Wesleyan missionaries first went to the Lau group of the Fiji Islands in 1835, utilising their connections through Tongan supporters that had relatives there. ${ }^{89}$ James Watkin contributed to the early Fiji effort by, upon request, writing an appeal which featured in the Wesleyan-Methodist Magazine in February 1838. Describing cannibalism and widow strangulation occurring in Fiji, Watkin urged those in England to support the new Fiji mission, whether financially, materially, prayerfully, or by new missionaries volunteering themselves for Fiji. ${ }^{90}$ Through this diffusion of information, readers in England and Europe became convinced of the need for Christianity in Fiji, in order to bring about an end to the reported violence such as cannibalism and to foster peace within Fijian society. Samuel Ironside remarked: 'That paper went to the heart of our people. A wave of sympathy for Fiji rolled over Methodist England; and the resolution was unanimously made that help must be at once rendered....The immediate result was the dedication of John Hunt and James Calvert to Fiji. ${ }^{91}$ Thomas J. Jaggar was also sent out from England to Fiji and Richard Lyth was transferred there from Tonga in $1839 .{ }^{92}$ Watkin's writing effectively bolstered early missionary efforts to Fiji, while Evison noted that it also contributed to Britain's eventual annexation of Fiji in 1874, which a Methodist MP Sir William Macarthur had pressed for. ${ }^{93}$ The efforts of Māori, Tongan and Samoan teachers, and a Rotuman converted in Tonga, assisted the earliest spread of Christianity in Rotuma. ${ }^{94}$ In subsequent decades the Methodist outreach went to Papua New Guinea and the Solomon Islands. Watkin therefore contributed to the growth of Christianity in Fiji and more directly in Tonga, the initial centre from which Methodism spread to other South Pacific islands.

\section{Missionary beginnings in New Zealand}

Before James Watkin arrived at Karitāne, missionary activity was well underway in the northern parts of New Zealand. After James Cook's first voyage to New Zealand from 1769

\footnotetext{
${ }^{89}$ ibid., pp. 30, 34.

${ }^{90}$ James Watkin, 'An Appeal to the Sympathy of the Christian Public, on Behalf of the Cannibal Fegeeans', The Wesleyan-Methodist magazine, Vol. 17, February 1838, pp. 150-152.

${ }^{91}$ Ironside, p. 733.

${ }^{92}$ Carter, p. 35.

${ }^{93}$ Evison, Te Wai Pounamu, p. 88.

${ }^{94}$ Carter, p. 39.
} 
to 1770 , more European vessels started visiting in search of timber and flax for shipbuilding, or seals and whales in order to produce commodities and for trade with Asia. ${ }^{95}$ While Europeans began to increasingly visit New Zealand, some Māori grew further acquainted with the outside world through travel and working in the South Pacific or on board foreign vessels. This is how the Anglican missionary Samuel Marsden met Ngāpuhi chief Ruatara, on board a ship heading from England to Australia. ${ }^{96}$ Marsden had wanted to establish a mission in New Zealand but he was deterred by conflict between Māori and Europeans in the 1809 Boyd incident. ${ }^{97}$ However by 1814 , Marsden's friendship with Ruatara paved the way for him and three other missionary couples to visit Rangihoua in the Bay of Islands and commence a mission, with Marsden preaching the first sermon in New Zealand directed towards Māori on the $25^{\text {th }}$ of December $1814 .^{98}$ This marked the beginnings of Church Missionary Society activity within New Zealand and a few years later they started a new mission station at Kerikeri.

Marsden returned to Sydney and later encouraged the Wesleyan missionary Samuel Leigh, who was also at New South Wales, to visit New Zealand to relieve his failing health. Leigh accordingly visited the Bay of Islands in 1819 and became convinced of the need for a Wesleyan mission there, promoting the cause for missions in New Zealand and Tonga after returning to England in $1820 .{ }^{99}$ Leigh was appointed to New Zealand and Walter Lawry to Tonga the following year, and in 1822 Leigh arrived at the Bay of Islands with his wife Catherine. ${ }^{100}$ A mission was established at Whangaroa and several more Wesleyan missionaries arrived in 1823; however the mission was raided by Ngāti Uru in 1827, resulting in its abandonment. The death of Whangaroa chief Te Ara, who had given protection to the missionaries, and a lack of understanding between the missionaries and local Māori may have

\footnotetext{
${ }^{95}$ Ballantyne, Entanglements of Empire, p. 3.

${ }^{96}$ Allan K. Davidson, Christianity in Aotearoa: A History of Church and Society in New Zealand (Wellington: The New Zealand Education for Ministry Board, 2004), p. 9.

${ }^{97}$ Angela Middleton, 'Missionization in New Zealand and Australia: A Comparison', International Journal of Historical Archaeology, Vol. 14, no. 1, 2010, pp. 174-175.

${ }^{98}$ Davidson, p. 9.

${ }^{99}$ George I. Laurenson, Te Hahi Weteriana: Three Half Centuries of the Methodist Maori Missions, $1822-1972$ (Auckland: Wesley Historical Society of New Zealand, 1972), pp. 7-8.

${ }^{100}$ Carter, p. 11; Middleton, p. 178.
} 
contributed to that event. ${ }^{101}$ In 1828 a new mission commenced at Māngungu in the Hokianga, and subsequent Wesleyan efforts developed down the west coast of the North Island. The first Roman Catholic missionaries arrived in the North Island in 1838, starting a mission under Bishop Jean Baptiste Pompallier in the Hokianga and shifting to Kororāreka (Russell) the following year. ${ }^{102}$ Early missionary activity concentrated on the North Island and for the WMS this was because they had first wanted to direct their limited funds towards extending the mission there. ${ }^{103}$

\section{Early nineteenth-century encounters in the southern South Island}

In the South Island, James Watkin's mission was directed towards Māori from the Kāi Tahu iwi and it is therefore useful to consider some of their background history in order to understand the context within which Watkin began his work there. The tribe of Kāi Tahu or Ngāi Tahu, descendants of Tahu Pōtiki from Hawkes Bay, began migrating into the South Island shortly after arriving in Wellington. ${ }^{104}$ They gained possession of the land through warfare and later intermarriage, with the dominant families of Ngāti Māmoe and Ngāi Tahu being well related by the close of the eighteenth century, having formed a peace arrangement and marriage alliances. Once the southern peoples, including Kāti Waitaha, were fairly united the term Ngāi Tahu came into general use. ${ }^{105}$ Europeans conducted sealing operations in southern New Zealand from the 1790s to 1827, the flax trade between 1813 and the 1840s, and established the first South Island whaling station in $1827 .{ }^{106}$ Hana O'Regan noted that Kāi Tahu had a mutually beneficial relationship with the Europeans, welcoming the additions of trade and development so long as Kāi Tahu rakatirataka (sovereignty) and mana over the

\footnotetext{
${ }^{101}$ Middleton, p. 178; Davidson, p. 13.

102 Davidson, pp. 13, 16; Claudia Orange, The Treaty of Waitangi, 2nd ed. (Wellington: Bridget Williams Books, 2011), p. 19.

${ }^{103}$ Report from the Select Committee appointed to Inquire into the Statements contained in the Petition of the Merchants, Bankers, and Shipowners of the City of London, (Presented 22d May 1840,) respecting the Colonization of New Zealand; together with the Minutes of Evidence taken before them, and an Appendix and Index. (London: House of Commons, 1840), p. 95.

${ }^{104}$ Anderson, The Welcome of Strangers, pp. 23, 27. 'Kāi' and 'Ngāi' are equivalent terms but the first spelling reflects the subdialect originally used by Māori in the southern South Island, while the latter term was more commonly used by tribes further north.

105 ibid., pp. 57, 26; Evison, Te Wai Pounamu, pp. 12, xviii.

${ }^{106}$ Anderson, The Welcome of Strangers, p. 75; Major, p. 16.
} 
area was respected. ${ }^{107}$ Stevens has linked these early interactions, between Kāi Tahu and Euroamericans, to Kāi Tahu adopting the English language earlier and relinquishing te reo Māori sooner than other tribes. ${ }^{108}$ Contact with Europeans also led to the acquisition of new weapons, with fatal consequences as tribes engaged in warfare. Starting in the North Island, the musket wars between 1806 and 1845 resulted in thousands being displaced, injured or killed, tribes being pushed southward and tribal boundaries redrawn. ${ }^{109}$ In 1827, Ngāti Toa chief Te Rauparaha began conducting raids against the South Island from his base at Kāpiti, where his people had migrated due to pressure from surrounding iwi for the fertile lands that Ngāti Toa Rangatira possessed at Kāwhia. ${ }^{110}$ In the following six years Te Rauparaha's attacks continued, leaving in its wake a significantly diminished Kāi Tahu population. Hōne Tūhawaiki led raids against Te Rauparaha, and by the early 1840s he had emerged as a distinguished Kāi Tahu chief of leading Kāi Tahu and Ngāti Māmoe descent. ${ }^{111}$ Signs of the conflict were visible when James Watkin arrived in the South Island in 1840. In a letter to his cousin the Rev. Joseph Entwistle from Tadcaster, Watkin commented: 'such is the fear of the people that scores of miles before you reach Cook Strait, which separates the two islands, you cease to meet with a Native. Those who have escaped the exterminating wars waged against them by Taraupaha [Te Rauparaha] have settled here and at other places more to the southward. 112 The musket wars had impacted the distribution of Māori across the North and South Islands of New Zealand. Population decreases resulting from these wars underlined the need for peace.

Māori were the sole inhabitants at Karitāne until 1837, when it was also occupied by Wright and Long of Sydney who intended for it to be a whaling station; by this point there were whaling stations already at Ōtākou and Onekakara near Moeraki. ${ }^{113}$ The protection and

\footnotetext{
${ }^{107}$ Hana O’Regan, Ko Tahu, Ko Au: Kāi Tahu Tribal Identity (Christchurch: Horomaka Publishing, 2001), p. 79.

${ }^{108}$ Stevens, p. 131.

${ }^{109}$ Philippa Mein Smith, A Concise History of New Zealand (Melbourne: Cambridge University Press, 2012), p. 39.

${ }^{110}$ ibid., p. 37.

111 Anderson, The Welcome of Strangers, p. 94.

${ }^{112}$ Pybus, 'Rev. James Watkin: An Unpublished Letter', p. 3.

113 John Christie, History of Waikouaiti, $2^{\text {nd }}$ edition (Christchurch: Christchurch Press Company Limited, 1929), pp. 34, 143, 62; Shortland, pp. 106, 301.
} 
permission of local chiefs was needed for the shore whaling station to operate, while the land was allocated on the authority of the chief. ${ }^{114}$ Due to insolvency, in 1838 the shore whaling station at Karitāne was purchased by John Jones who continued the enterprise. ${ }^{115}$ Jones' ship Magnet transported chiefs Taiaroa, Karetai, Tūhawaiki, Topi Patuki and Haereroa to Sydney in 1838 , at which point they were said to have sold large tracts of land to Jones and other merchants. ${ }^{116}$ While the chiefs' used the income to maintain their combatants, Evison commented: "whether they knew that Jones and his fellow-merchants were laying claim in Sydney to the ownership of hundreds of thousands of hectares of the best Ngai Tahu coastal lands, and that this might jeopardize the very communities that the chiefs were anxious to defend, is far from clear. ${ }^{117}$ Māori did not share the European concept of private property but owned land communally. ${ }^{118}$ Land sales that took place prior to the Treaty of Waitangi were later investigated, nullifying much of John Jones' excessive claims to land in the South Island. ${ }^{119}$ Once whaling commenced at Karitāne, many Māori migrated there from other parts of the South Island, mainly from the north, in order to obtain European goods by their labour or by trading resources such as potatoes and pigs. ${ }^{120}$ They gained employment as whalers, coopers, carpenters and at other trades. ${ }^{121}$ According to Walter Mantell's records, by the 1840s many at Karitāne aligned with Ngāti Huirapa, Ngāti Rakiamoa and Ngāi Tūāhuriri hapū (kinship groups). ${ }^{122}$ In June 1840, southern chiefs Tūhawaiki, Kaikoura and Taiaroa signed the Treaty of Waitangi at Ruapuke Island which is near Stewart Island, and the signatures of Hoani Karetai and Korako were secured at Otago. ${ }^{123}$ In following Lieutenant Governor William Hobson's instructions, after Major Thomas Bunbury finished gathering

\footnotetext{
$\overline{{ }^{114} \text { Evison, Te Wai Pounamu, p. } 88 .}$

${ }^{115}$ Shortland, pp. 106, 301; Christie, pp. 143, 62.

${ }^{116}$ Christie, pp. 67, 75; Major, p. 33; Evison, Te Wai Pounamu, pp. 96-97.

${ }^{117}$ Evison, Te Wai Pounamu, p. 97.

118 ibid., p. 96.

${ }^{119}$ Ballantyne, 'Paper, Pen, and Print', p. 247.

${ }^{120}$ Shortland, p. 115; Anderson, The Welcome of Strangers, p. 172.

${ }^{121}$ Christie, p. 63.

${ }^{122}$ Anderson, The Welcome of Strangers, p. 104.

${ }^{123}$ Robert McNab, The Old Whaling Days: A History of Southern New Zealand from 1830 to 1840 (Wellington: Whitcombe and Tombs Limited, 1913), p. 377; Belmer, p. 30.
} 
signatures he proclaimed British sovereignty over the South Island on 17 June 1840 at Port Underwood, considering this the most effective way to prevent further conflict between Europeans and Māori. ${ }^{124}$ Around 1839 there were an estimated 2,000 permanent European settlers in New Zealand, with about 600 in the South Island and 1,400 in the North Island. ${ }^{125}$ Māori population estimates in New Zealand ranged from 70,000 to 180,000, although the Māori population at Otago in 1844 was around five hundred. ${ }^{126}$ Kāi Tahu living at Port Levy first learnt about Christianity from Taawao, who came from the West Coast where he had been instructed by a Ngāpuhi Wesleyan from the north of Auckland. ${ }^{127}$ The first Christian minister to visit the South Island had been the Wesleyan missionary William White in April 1836. $^{128}$

\section{Voyage to Karitāne}

After their six years in Tonga, Watkin and his family moved to Sydney, briefly stopping at the Bay of Islands on the way to Port Jackson. ${ }^{129}$ Watkin worked as second preacher in Sydney until the 1839 session of the English Wesleyan Conference appointed him to Kāpiti in the lower North Island of New Zealand. ${ }^{130}$ However, after the Anglican missionary Octavius Hadfield started working at Ōtaki on the Kāpiti coast, John H. Bumby the Superintendent of the Methodist Mission in New Zealand advised the Sydney Missionary Committee to find Watkin another appointment. ${ }^{131}$ Bumby and missionary John Hobbs had visited the South Island in June 1839 and gave positive feedback to the Wesleyan Mission Board at Sydney for a mission to be established there. ${ }^{132}$ Ōtākou chiefs Karetai and Taiaroa

\footnotetext{
${ }^{124}$ Evison, Te Wai Pounamu, pp. 132, 134; Orange, p. 82.

125 Orange, p. 1.

${ }^{126}$ Davidson, p. 26; Olssen, p. 28.

${ }^{127}$ Pratt, 'Early Methodism in Canterbury', p. 27; Pybus, 'Heroic Pioneer Workers', p. 2; Pybus, Maori and Missionary, pp. 67-68.

${ }^{128}$ Pybus, Maori and Missionary, p. 1.

${ }^{129}$ Pratt, 'JAMES WATKIN: Otago’s Religious Pioneer', p. 2.

${ }^{130}$ Watkin, Journal Vol. 1, 25 September 1837, p. 276; Pratt, 'JAMES WATKIN: Otago's Religious Pioneer', p. 3.

${ }^{131}$ Pratt, 'Ninety Years Ago', 13 June 1931, p. 1.

${ }^{132}$ Pybus, 'The Rev. James Watkin and the Otakou Mission', p. 22.
} 
also pressed for a missionary during their visit to Sydney. ${ }^{133}$ They reasoned that the South Island should benefit as the North Island had from the presence of missionaries, churches and schools to teach Christianity, literacy and other skills. ${ }^{134}$ John Jones offered to provide land for a mission station, fifty pounds sterling towards its establishment, and to transport the missionary with his family and goods to Karitāne. He later paid for the missionary house and a chapel to be built there. ${ }^{135}$ Watkin accepted the post, although his Wesleyan congregants signed two petitions requesting that he remain, addressed to the General Superintendent and the District Meeting. ${ }^{136}$ His appointment stood nevertheless, although they did not depart on Jones' barque the Magnet as intended because it was overcrowded. ${ }^{137}$ The Magnet transported thirty-eight persons to the Karitāne area in March 1840, where they formed the first farming settlement in the South Island. ${ }^{138}$ Although John Jones himself remained in Sydney, some of his family members including his brother Thomas were in New Zealand. ${ }^{139}$ The Watkins stayed with Jones' family in Sydney for seven weeks while waiting for another one of Jones' vessels to depart for Karitāne. ${ }^{140}$ On Friday 1 May 1840, the Watkin family were seen off by many friends including the Joneses as they left Sydney aboard the Regia. ${ }^{141}$ Aside from the horses, cattle and sheep being transported by the vessel, their only fellow passenger was a young man named William Morgan, who shortly after returned to Sydney. ${ }^{142}$ They soon approached their destination and on 12 May came in danger of shipwreck when passing through Foveaux Strait, as the wind died down and islands began to appear fearfully close. Watkin awoke his wife and they prayed for deliverance, feeling confident that it would

\footnotetext{
133 ibid.

${ }^{134}$ Pybus, Otakou, A Story of Far-off Days, p. 5.

135 James Watkin, Letter to the Secretaries of the Wesleyan Missionary Society, 18 June 1840, Methodist Missionary Society Records, Reference Number: Micro-163, Reel 20, Hocken Collections, University of Otago, p. 2.

${ }^{136}$ Pratt, 'Ninety Years Ago', 13 June 1931, p. 1; Watkin, Letter to the Secretaries of the WMS, 18 June 1840 , p. 1.

${ }^{137}$ Watkin, Letter to the Secretaries of the WMS, 18 June 1840, p. 2.

${ }^{138}$ Evison, Te Wai Pounamu, pp. 118, 124.

${ }^{139}$ Watkin, Journal Vol. 2, 16 and 24 May 1840, pp. 298, 299.

${ }^{140}$ Watkin, Letter to the Secretaries of the WMS, 18 June 1840, p. 3.

${ }^{141}$ Watkin, Journal Vol. 2, 1 May 1840, p. 295.

142 ibid., 2 May 1840, p. 296; Pratt, 'Ninety Years Ago', 13 June 1931, p. 1.
} 
be granted them, and the Captain soon after declared them out of danger. ${ }^{143}$ Due to calms and contrary winds, it was four days later that they came ashore at Ohinetemoa, which the Waikouaiti Bay beach had been known as. ${ }^{144}$

\footnotetext{
${ }^{143}$ Watkin, Journal Vol. 2, 12 May 1840, p. 297.

144 ibid., 15 and 16 May 1840, pp. 297, 298; Pratt, The Pioneering Days, p. 54.
} 


\section{Chapter 1: Fostering peace in the local community}

James Watkin helped to foster peace within the local communities where he was stationed and among those in connection with the Wesleyan church services and schools. This chapter considers how Watkin learnt te reo Māori to enable him to communicate with Māori and preach the gospel to them, by which means Christian teachings in support of peaceful conduct could be dispersed throughout the community. Watkin also preached to European congregations with the intent of Christianity having a positive moral influence on their conduct. Persons from all ranks in Māori society came to be baptised and the conversion of chiefs was particularly useful for encouraging peace and Christianity among their people. The chapter examines how the gospel was further communicated through schools, which taught Māori literacy in their own tongue, enabling them to read the Bible and Christian texts and later to engage peacefully with the Crown and government through writing. It then reviews how, by cases of more direct intervention, Watkin worked to deter violence and to promote the worth of all members of society.

\section{Communicating the gospel through preaching}

On 16 May 1840, James Watkin first sighted Karitāne and noted that Māori appeared pleased at the arrival of a missionary among them. ${ }^{1}$ He came ashore at around midday with his wife Hannah Watkin and their five children, James Entwisle aged nine, William Jackson aged seven, Hannah Jane aged four, Jabez Bunting aged three, all born in Tonga, and Edwin Iredale aged eleven months old and born in Sydney. ${ }^{2}$ The following day being Sunday, Watkin held a service in English which he stated was well attended by whalers, some agriculturalists and many Māori. He opened his commission in New Zealand by preaching from the book of 1 Timothy chapter 1 and verse 15 (KJV): 'This is a faithful saying, and worthy of all acceptation, that Christ Jesus came into the world to save sinners; of whom I am

\footnotetext{
${ }^{1}$ James Watkin, Journal of James Watkin, Vol. 2, 1840-1882, Reference Number: fMS-255, Alexander Turnbull Library, 16 May 1840, p. 298.

2 James Watkin, Journal of James Watkin, Vol. 1, 1830-1839, Reference Number: fMS-254, Alexander Turnbull Library, 16 May 1831, 3 January 1833, 14 December 1834, 31 March 1837, 10 June 1839, pp. 46, 110, 214, 274, 283; M. A. Rugby Pratt, The Pioneering Days of Southern Maoriland (London: Epworth Press, 1932), p. 54. James Entwisle's obituary stated that he was 'the first white child born in the Friendly Islands [Tonga]'. See 'MR. J. E. WATKIN.', The Sydney Morning Herald, 15 December 1925, p. 7.
} 
chief. ${ }^{3}$ Despite initially not understanding Watkin due to the language barrier, Māori showed an interest in attending the religious services he held. Similarly, Samuel Marsden's first sermon to Māori in the North Island was spoken in English while Ruatara interpreted for it, although in Watkin's case no translator is mentioned. ${ }^{4}$ On 31 May 1840, Watkin held an afternoon service in English at the carpenter's shop, noting that: 'a considerable number of the natives were present to witness the "karakia bora" (the English mode of worship) I hope soon to be able to make known unto them in their own tongue the wonderful works of God., ${ }^{5}$ When he held a service the following week at Matainaka, where the agriculturalists employed by John Jones were located, a greater number of Māori than Europeans attended and were attentive, despite not understanding what was said. ${ }^{6}$ Watkin chose to reside within Karitāne, rather than at Mataīnaka, so that he could live close by the Māori community and focus on ministering to their spiritual welfare. ${ }^{7}$ His cottage was built between the whalers' huts, with the whaling station being located on the southern side of the Waikouaiti River mouth, and the Māori kāinga or village which was a short distance upstream from this. ${ }^{8}$ This enabled Māori to regularly interact with the Watkin family and most importantly the Christian ideas and practices that Watkin wanted them to adopt as their own.

In order to clearly communicate the gospel of peace to Māori, Watkin first needed to become acquainted with the Māori language. In his first letter from Karitāne to the Wesleyan Methodist Missionary Society in London, he reported: 'I have to learn a language which is as yet unwritten; being the first Xian [Christian] Missionary who has set foot on this Island for the purpose of instructing the inhabitants in the "things which make for their peace". This will require severe application, as I have to act the pioneer; and will take a considerable time.

\footnotetext{
${ }^{3}$ Watkin, Journal Vol. 2, 17 May 1840, p. 298.

${ }^{4}$ Alison Jones and Kuni Jenkins, He Kōrero - Words Between Us: First Māori-Pākehā Conversations on Paper (Wellington: Huia, 2011), p. 83.

${ }^{5}$ Watkin, Journal Vol. 2, 31 May 1840, pp. 299-300.

${ }^{6}$ ibid., 7 June 1840, p. 300.

7 ibid., 18 and 26 May 1840, pp. 298, 299.

${ }^{8}$ Harry C. Evison, Te Wai Pounamu - The Greenstone Island: A History of the Southern Maori during the European Colonization of New Zealand (Wellington and Christchurch: Aoraki Press, 1993), pp. 152, 151.
} 
It differs essentially from the written language of the North Island'. ${ }^{9}$ Watkin identified how enhancing his skills in te reo Māori was crucial for teaching Māori about the Christian message of peace. He was surprised to find that the dialect spoken by Kāi Tahu differed from that used in the North Island, initially causing him to question whether books published by the Wesleyan mission press at Hokianga would be of any use. ${ }^{10}$ The Māori orthography still in use today was established by the 1820 book A Grammar and Vocabulary of the Language of New Zealand which was informed by the dialect spoken by Ngāpuhi in the north. ${ }^{11}$ In the south when Watkin read to them from the New Testament published at Paihia, he asked if they understood and the response was "Kahore e matou" that they did not. ${ }^{12}$ While their lack of understanding the text could partly relate to Watkin's pronunciation, as he was still new to learning Māori, the dialect spoken in the southern South Island did have its variances from that spoken further north. Evison commented: 'Not only were many word meanings different, but Southern Maori was spoken with a distinctive and rather guttural accent. For example the northern Maori $n g$ was pronounced " $k$ " or " $g$ " in the south, and the $r$ and $p$ sounded more like "l" and " $b " ., 13$ Kāi Tahu reo contained consonants not often used in the north, such as g, 1, v, b and d. ${ }^{14}$ Edward Marsh Williams, son of the Rev. Henry Williams, was a skilled interpreter but also experienced difficulty communicating in the southern South Island in 1840. Williams accompanied Major Bunbury to Otago to gather signatures for the Treaty of Waitangi, with his role being to explain the document to the chiefs. Struggling to be understood, Williams needed the assistance of a visiting Māori who was familiar with the northern Ngāpuhi dialect that he knew, to act as an intermediary. ${ }^{15}$ Considering how important language would be for the mission work, James Watkin was initially unsettled by these linguistic differences but in time he became better acquainted with the local tongue. Learning the language remained essential in order to conduct church services, run schools and translate texts. Ballantyne noted

\footnotetext{
${ }^{9}$ James Watkin, Letter to the Secretaries of the Wesleyan Missionary Society, 18 June 1840, Methodist Missionary Society Records, Reference Number: Micro-163, Reel 20, Hocken Collections, University of Otago, p. 1.

${ }^{10}$ ibid.

${ }^{11}$ Jones and Jenkins, pp. 164, 161.

12 James Watkin, Letters to James Buller, Catalogue No. MS207, Methodist Church of New Zealand Archives, 1840-1844, 14 September 1840, p. 2.

${ }^{13}$ Evison, Te Wai Pounamu, p. 12.

${ }^{14}$ Hana O’Regan, Ko Tahu, Ko Au: Kãi Tahu Tribal Identity (Christchurch: Horomaka Publishing, 2001), p. 65.

${ }^{15}$ Pratt, The Pioneering Days, p. 109.
} 
that te reo Māori was: 'the functional language of the mission. It was the language of the native service, the language of educational and social instruction, and the primary idiom of cross-cultural communication. Most important, it was the language of scripture'. ${ }^{16}$ For Māori to be able to read the scriptures in their own language, they would first need to be taught literacy.

Before Watkin could commence schools to teach Māori how to read and write, he needed to personally have a basic knowledge of te reo Māori. His learning was therefore accompanied by a sense of urgency and necessity. By June 1840, Watkin had collected nearly four hundred words and phrases in the southern Māori dialect and in September he received assistance in the language from the chief Tohiti Haereroa, who for a time resided with them as a servant and professed conversion to Christianity. ${ }^{17}$ As Petrie noted, men and women of varying ranks could work as servants in the missions. ${ }^{18}$ Receiving Māori assistance was essential for learning the language and it was likely sought out when texts were being translated as well, although missionary accounts often neglected to mention indigenous assistance in the translation work. ${ }^{19}$ Pratt noted that Watkin carried with him everywhere a red morocco pocket-book, writing down each word he heard and wherever possible the meaning. ${ }^{20}$ Initially Watkin used his incomplete knowledge of te reo Māori to communicate with those Kāi Tahu who had acquired some use of the English language, allowing for basic intercommunication on common subjects. While James Watkin had the benefit of experience, having learnt another language and undertaken translation work in Tonga, his prior knowledge of Tongan had the potential to both assist and to complicate his progress in te reo Māori. According to Samuel Ironside, the similarities and common origin shared between the Tongan and Māori languages greatly helped Watkin with learning Māori. ${ }^{21}$ On the other hand, when Edwin

\footnotetext{
${ }^{16}$ Tony Ballantyne, Entanglements of Empire: Missionaries, Māori, and the Question of the Body (Auckland: Auckland University Press, 2015), p. 5.

${ }^{17}$ Watkin, Journal Vol. 2, 5 June and 8 September 1840, pp. 300, 306; Pratt, The Pioneering Days, pp. 171-172.

${ }^{18}$ Hazel Petrie, Outcasts of the Gods? The Struggle over Slavery in Māori New Zealand (Auckland: Auckland University Press, 2015), p. 224.

${ }^{19}$ Jane Samson, 'Translation Teams: Missionaries, Islanders, and the Reduction of Languages in the Pacific' in Grimshaw, Patricia and May, Andrew (eds.), Indigenous Peoples and Cultural Exchange (Eastbourne: Sussex Academic Press, 2010), p. 97.

${ }^{20}$ Pratt, The Pioneering Days, p. 112.

${ }^{21}$ Samuel Ironside, A Biography of James Watkin: a pioneer missionary in the Friendly Islands and in New Zealand, ex-president of the Australian Conference (London: 1891), p. 734.
} 
Watkin donated his father's handwritten Vocabulary of Māori Words book from Karitāne to Dr Thomas Morland Hocken, he wrote: 'I have no doubt that the vocabulary would have been much more complete, if my father, had not been familiar with a cognate language, that of Tonga. ${ }^{22}$ The similarities between Tongan and Māori meant that Watkin would need to be careful where words within the two languages seemed similar but in fact had different meanings.

Through Watkin's basic knowledge of te reo Māori, he attempted to communicate Christian concepts to Māori. He conversed about Christian ideas with his family's nearest neighbour Kurukuru, a notable chief at Karitāne from the Kāti Huirapa hapū, while Kurukuru would inform him about the past state of New Zealand and its inhabitants. ${ }^{23}$ Evison noted that chiefs visited Watkin's house to discuss religious doctrine, as philosophical dispute rated highly in Māori culture. ${ }^{24}$ Watkin commented in June 1840 after talking to Kurukuru about a future state, heaven 'Te kaika pai' and hell 'Te Kaika kino': 'I have little doubt, but that he will talk about these things, and in more intelligible Mauri (New Zealand) [Māori] than I can command, and that good will come of it. In the morning sow thy seed, and in the evg [evening] withhold not thy hand'. ${ }^{25}$ In speaking of a heaven and a hell, Watkin was trying to draw his hearers to themes of eternal significance as a matter of priority. After speaking to Māori on the topic of the resurrection of the body, Watkin was pleased to report that: 'inquiry after these things appears to be excited and the Missionary and Gods Book are subjects of pretty general conversation. ${ }^{26}$ Christian ideas were spreading around the community, as a topic of interest and curiosity. Watkin was likewise undergoing a process of new learning, as Ballantyne wrote: 'missionaries were also drawn into the mental world of Māori. In order to Christianize Māori society, missionaries first had to grasp the operation of essential social laws, develop a basic understanding of local politics and kin-group rivalries, and gain

\footnotetext{
${ }^{22}$ Copy of Watkin, James: Vocabulary of Maori Words, Reference Number: PC-0038, Hocken Collections, University of Otago. Edwin Iredale Watkin donated the manuscript to Thomas M. Hocken; pasted on the inside cover of the book is an accompanying letter from Edwin to Hocken, dated 29 March 1893.

${ }^{23}$ Watkin, Journal Vol. 2, 23 June and 13 July 1840, 6 March 1841, pp. 302, 303, 319; Pratt, The Pioneering Days, p. 89. While James Watkin appears to have written 'Kurukuru' in his journal entries, M. A. R. Pratt consistently referred to him as Kurakura.

${ }^{24}$ Evison, Te Wai Pounamu, p. 153.

${ }^{25}$ Watkin, Journal Vol. 2, 23 June 1840, p. 302.

${ }^{26}$ ibid., 24 June 1840, p. 303.
} 
linguistic competence in spoken Māori. ${ }^{27}$ It remained important for Watkin to enhance his understanding of the society within which he was operating, in order to labour more effectively in his missionary efforts. By conversing with local Māori, Watkin was able to impart knowledge about Christianity to his hearers while they imparted knowledge about Māori society and history to him.

By attending the church services that James Watkin established and conducted, congregants heard the peaceful ideas promoted by Christianity. By mid-September of 1840, Watkin's skills in te reo Māori had advanced to the point where he could address Māori congregations without a script. ${ }^{28}$ Watkin described his typical weekly schedule in a letter he sent to the WMS early in 1841:

My work here may be thus described, on Sunday I have a native service here [Karitāne] at seven o clock in the morning, I then walk over to Matainach [Matainaka] about four miles along a beach ... there I conduct an English service and have a few who constantly attend it, and then a native one at which most of the natives are present, after my return I have two other services at this place, one for the English another for the natives in both of which I use parts of the Liturgy of the Church of England in addition to the usual Wesleyan Plan of singing, preaching \& c. .... On the week days I have two schools for the natives at this place in the morning at six and in the evening at five, and twice a week at Matainach in the afternoon. In the forenoons I conduct an English School for the benefit of my own children and some others of European Extraction, and throughout the day am employed in one way or other in the study of the language \& c ... I have an English service on a Wednesday evening, and may almost be said to have one for the natives every evening. ${ }^{29}$

These efforts made church services and school classes accessible to Māori and Europeans at Karitāne and Mataīnaka each week. Watkin noted in September 1841 that Māori from most other parts of the South Island were also in the habit of occasionally visiting Karitāne and attending the church services. ${ }^{30}$ In June 1842, Watkin estimated that his Māori congregation

\footnotetext{
${ }^{27}$ Ballantyne, Entanglements of Empire, p. 5.

${ }^{28}$ Watkin, Journal Vol. 2, 14 September 1840, p. 306.

${ }^{29}$ James Watkin, Letter to the General Secretaries of the Wesleyan Missionary Society, January 1841, Methodist Missionary Society Records, Reference Number: Micro-163, Reel 20, Hocken Collections, University of Otago, p. 2.

${ }^{30}$ James Watkin, Letter to the Secretaries of the Wesleyan Missions, 30 September 1841, Methodist Missionary Society Records, Reference Number: Micro-163, Reel 21, Hocken Collections, University of Otago, p. 3.
} 
at Karitāne was an average of fifty. ${ }^{31}$ By 1843-1844 Shortland recorded a Māori population at Karitāne of forty-one men, thirty-two women and twenty-eight children, excluding eleven women who lived with whalers and their fourteen children of mixed Anglo-Māori ethnicity. ${ }^{32}$ Nelson settler Dr David Monro also visited Karitāne in 1844 and noted that the Māori population there averaged one hundred and twenty. ${ }^{33}$ These figures suggest that roughly just under half of the Māori inhabitants at Karitāne regularly attended church services, although this may have increased later as baptisms did. Watkin stated that his congregation was greater at Moeraki, thirty-five kilometres north of Karitāne, where he estimated there to be nearly two hundred inhabitants in $1842 .{ }^{34}$ Shortland likewise estimated that Moeraki had a population of two hundred while George Selwyn recorded a figure of one hundred by $1844 .{ }^{35}$

While Watkin preached to them of Christianity, it was his hearers that ultimately had to choose whether to align their conduct with what he instructed. Although cultural and linguistic barriers may have hindered the effective conveyance of some of the deeper Biblical ideas to Māori at the time, some of the essential messages were nevertheless understood. In a journal entry for November 1840, Watkin recorded:

I was pleased yesterday with what I heard from one of the natives and which shews that Xy [Christianity] is exercising some influence. He stated that he had been wronged by a white man, and that the latter proposed fighting as a termination of the matter. The Native said "No, the Missionary tells us it is wrong to fight and I will not fight". This tho' a little circumstance is encouraging, for the native is a powerful man and quite able to thrash the white offender soundly, and he was not formerly remarkable for forbearance. The natives bring their troubles to the Missionary for him they regard as their Friend. ${ }^{36}$

\footnotetext{
${ }^{31}$ Watkin, Journal Vol. 2, 4 June 1842, p. 332.

${ }^{32}$ Edward Shortland, The Southern Districts of New Zealand; A Journal, with Passing Notices of the Customs of the Aborigines (Christchurch: Caper Press, 1974), p. 115.

${ }^{33}$ David Monro, 'Notes of a Journey through a part of the Middle Island of New Zealand' in Hocken, Thomas M., Contributions to the Early History of New Zealand (Settlement of Otago), (London: Sampson Low, Marston and Company, 1898), p. 241; Evison, Te Wai Pounamu, p. 200.

${ }^{34}$ Watkin, Journal Vol. 2, 5 February and 4 June 1842, pp. 328, 332; Evison, Te Wai Pounamu, p. 152.

35 Atholl Anderson, The Welcome of Strangers: An ethnohistory of Maori A.D. 1650-1850 (Dunedin: University of Otago Press, 1998), p. 190.

${ }^{36}$ Watkin, Letter to the General Secretaries of the WMS - Journal Extracts, January 1841, p. 11. See also Watkin, Journal Vol. 2, 16 November 1840, p. 312.
} 
This serves as an example of how the preaching of the gospel worked to discourage conflict. Some of Watkin's hearers were receptive and willing to follow the missionary's advice. Owens however has noted that Māori: 'did not always adopt the habits and values the missionaries thought they should; they were not dominated by the missionaries. ${ }^{37}$ There were variations in whether Māori accepted Christianity or not and the degree to which they conformed to it. In the case above, the individual mentioned had personally decided to follow the missionary's teachings against fighting, having evidently reasoned that there was merit in doing so. Cannibalism also appears to have ended at Karitāne around the time of James Watkin's arrival there, with the last report of it taking place in 1840 when Tūhawaiki returned from conducting raids against Te Rauparaha. ${ }^{38}$ There may have also been economic motives for refraining from the practice, for example so as not to deter Europeans from trading with them. ${ }^{39}$ However, missionaries were known to customarily denounce cannibalism and the missionary's influence upon those in connection with the mission would have encouraged an unfavourable view of the practice, thereby helping to ensure that the act was not continued.

Watkin also preached to European congregations, where it similarly remained in their hands whether to follow his advice or otherwise. The English church services were initially held in the carpenter's shop and Watkin ran a weekly service at Matainaka for the agriculturalists. ${ }^{40}$ In 1840, John Jones had brought twelve families and several single men to the area from New South Wales, on the promise that they would receive sixty acres of land after two years under his employment. ${ }^{41}$ While the settlement languished under the management of Jones' brother, conditions improved when Jones returned and took control, and in 1844 there were thirty families working for him. ${ }^{42}$ Visitor David Monro was informed in 1844 that there were about one hundred Europeans living at Karitāne, most as whalers, many working on Jones' farm

\footnotetext{
${ }^{37}$ J. M. R. Owens, 'Christianity and the Maoris to 1840 ', New Zealand Journal of History, Vol. 2, no. 1, 1968, p. 39.

${ }^{38}$ John Christie, History of Waikouaiti, $2^{\text {nd }}$ edition (Christchurch: Christchurch Press Company Limited, 1929), pp. 143,43 .

${ }^{39}$ Petrie, Outcasts of the Gods?, p. 221.

${ }^{40}$ Watkin, Journal Vol. 2, 31 May and 7 June 1840, pp. 299, 300.

${ }^{41}$ Erik Olssen, A History of Otago (Dunedin: John McIndoe, 1984), p. 18.

${ }^{42}$ ibid., pp. 18-19.
} 
and some farming on their own account. ${ }^{43}$ At Omate, Watkin held services in the store run by Octavius Harwood at the Weller's Ōtākou whaling station, and Harwood later had his children baptised. ${ }^{44}$ In his journal in June 1840, Watkin recorded having Americans, Australians, English and Māori among his congregation. ${ }^{45}$ Writing to the Wesleyan Methodist Missionary Society secretaries that month, he reported: 'A goodly number of English are to be found in the various whaling parties, fixed at most of the convenient parts along the whole length of this Island, from Foveaux's to Cooks Straits, there are some settlers, and their number is likely to be increased. ${ }^{46}$ Watkin was interested in converting them as much as the indigenous inhabitants of the land, however his English congregations were small and he questioned whether they practiced what was preached to them. ${ }^{47}$ On occasion his preaching offended the European congregation, as Watkin noted on 23 July 1842: 'I have been informed that my plain speaking has given huge offence to certain of the Christians, and that I am to be punished by their non attendance in future, "The viper and the file". ${ }^{48}$ When he preached plainly he felt clear of their blood, meaning that he could have a clear conscience before God for having done his duty in warning the people against immoral behaviours, and he did not mind the repercussions to himself. ${ }^{49}$ While Watkin preached a gospel of peace, he did not try to attain an artificial semblance of peace by diluting the message; instead the peace would ideally be fostered by his listeners heeding what he preached to them.

John Jones had brought James Watkin and his family to Karitāne for the purpose of having a moral influence upon the inhabitants in the area, many of whom were his employees. As Watkin explained in a letter to the Secretaries of the Wesleyan Methodist Missionary Society in London, one month after he arrived at Karitāne: 'A $\mathrm{M}^{\mathrm{r}} \mathrm{J}$ John Jones Shipowner of Sydney, who has several Whaling Establishments on the Eastern coast of this Island, became affected

\footnotetext{
${ }^{43}$ Monro, p. 241.

44 Thomas A. Pybus, 'Otakou and the First Christian Mission: A Brief Statement' (Dunedin: Otago Daily Times print, 1940), Alexander Turnbull Library, p. 2.

${ }^{45}$ Watkin, Journal Vol. 2, 14 June 1840, p. 301.

${ }^{46}$ Watkin, Letter to the Secretaries of the WMS, 18 June 1840, p. 3.

${ }^{47}$ Watkin, Journal Vol. 2, 17 August 1840 and 10 October 1842, pp. 304, 337.

${ }^{48}$ ibid., 23 July 1842, p. 335.

${ }^{49}$ ibid., 28 August 1843 and 14 July 1842, pp. 353, 335.
} 
by the moral destitution of both the native inhabitants and white residents, and wished a Wesleyan Missionary might be sent. ${ }^{50}$ Being from New South Wales and of Welsh origin, as a boy Johnny Jones had worked as a sealer on the coast of the South Island, later becoming a waterman in Sydney and eventually a merchant. ${ }^{51}$ Between 1834 and the early 1840 s, Jones acquired and co-owned whaling stations at Rakituma (Preservation), Aparima (Jacob's River, now Riverton), Awarua (Bluff Harbour), Waikawa and Karitāne. ${ }^{52}$ Samuel Ironside noted that Jones was concerned for the religious welfare of his employees, there being possibly two hundred people. ${ }^{53}$ As an indication of some of the conduct that took place in the southern South Island before the advent of the law, Pratt recorded: 'In 1838, at Jones and Palmer's station at Preservation Inlet, a West Indian lad, for the accidental loss of a boat, was mercilessly beaten with a thick spliced rope-end and died in circumstances of the most revolting sort, yet no punishment overtook the guilty parties. ${ }^{54}$ Such occurrences underlined the need for the introduction of law to bring in accountability, and for positive moral influences which a missionary and the spread of Christianity could provide. Whaling however happened to be on the decline as fewer whales visited, resulting in less oil procured; they went from catching forty-one whales at Karitāne in 1838 to five whales in $1843 .{ }^{55}$ On 5 August 1843, Watkin recorded the unexpected arrival of Jones' family from Sydney, having likely come due to the commercial pressures of New South Wales. ${ }^{56}$ Shortland noted that most Sydney merchants had suffered ruin around that time as a result of wild speculations and a system of credit being taken to an extreme. ${ }^{57}$ Jones and his family retired to New Zealand where he still held property, although from 1843 he was no longer the sole proprietor of the Karitāne whaling station. ${ }^{58}$ After John Jones' arrival, Watkin reported in early September 1843 that his English church services were better attended than usual, attributing

\footnotetext{
${ }^{50}$ Watkin, Letter to the Secretaries of the WMS, 18 June 1840, pp. 1-2.

${ }^{51}$ Christie, p. 70; Shortland, pp. 106-107.

${ }^{52}$ Shortland, pp. 300-301.

${ }^{53}$ Ironside, p. 733.

${ }^{54}$ Pratt, The Pioneering Days, p. 33.

${ }^{55}$ Shortland, pp. 177, 301.

${ }^{56}$ Watkin, Journal Vol. 2, 5 August 1843, p. 352.

${ }^{57}$ Shortland, pp. 107-108.

58 ibid., pp. 108, 301.
} 
this to respect for Jones. ${ }^{59}$ Jones likely wanted his employees to attend the services for the positive moral influence that they might have upon them, which would work to promote a peaceful community less tainted by contentious conduct. Jones continued to show support for the mission and in 1844 Watkin visited various Māori communities southward on Jones' Schooner Scotia. ${ }^{60}$ Having a respect for religion, Jones later donated land and funds to the Episcopal Church, Presbyterian Church and Roman Catholic Church as well the Wesleyan Church. ${ }^{61}$ Jones perceived that supporting Christianity would be beneficial for the wellbeing of the community.

Drunkenness was a key problem plaguing the European community. Shortland stated that spirits were not as generally consumed by Māori at the time and early observers similarly commented on Māori having distaste for strong liquor; over time however, those located closer to Europeans began adopting the habit. ${ }^{62}$ Some Māori living near whaling stations at Otago consumed alcohol, such as that sold to them at the boiling-down stations. ${ }^{63}$ Yet excessive drinking was not recognised as a serious issue among Māori until later in the nineteenth century. ${ }^{64}$ The initial set up on whaling stations created a problem of excessive alcohol consumption among whalers at Karitāne. As Shortland explained, workers were paid a percentage of the oil obtained from the whales and after the whaling season ended, the whaling station owner's ship would visit carrying spirits and goods. The whalers were granted credit to spend on these items in accordance with their share of the oil, which often resulted in them drinking until their credit ran out. ${ }^{65}$ Pratt also wrote that in 1837 most of the whalers earned three shillings a day and others $£ 12$ a tun for the oil, paid in provisions, clothing and rum from the master's stores. ${ }^{66}$ The ship would then carry the oil to Sydney and

\footnotetext{
${ }^{59}$ Watkin, Journal Vol. 2, 11 September 1843, p. 354.

${ }^{60}$ ibid., 22 February 1844, p. 363.

${ }^{61}$ Christie, p. 72.

${ }^{62}$ Shortland, p. 116; Vincent O’Malley, The Meeting Place: Māori and Pākehā Encounters, 1642-1840 (Auckland: Auckland University Press, 2012), p. 141.

${ }^{63}$ Olssen, p. 24; Pratt, The Pioneering Days, p. 29.

${ }^{64}$ O’Malley, p. 141.

${ }^{65}$ Shortland, pp. 109-111.

${ }^{66}$ Pratt, The Pioneering Days, p. 30.
} 
sell it for a much greater price than the whalers had obtained in goods, profiting the whaling station owner. ${ }^{67}$ According to Shortland, this had effectively meant that the whalers: 'had scarcely a choice between not being paid at all, or else paid in rum; and so being made drunkards whether they would or no. ${ }^{68}$ Referring to these conditions in 1841 , Watkin commented that the area of Karitāne was: 'one of the most drunken on the coast. This is the fault of the person in charge, if I had known how things would have been misconducted down here, no consideration would have induced me to come'. ${ }^{69}$ It was no coincidence that Watkin had previously been ignorant of this state of affairs; the letters of whaling station workers were destroyed at sea to prevent information about the fisheries being made public in Sydney. The workers also had difficulty leaving the place, as their employer's vessels would not take them and few other ships came close enough. ${ }^{70}$ However, by the time that Shortland visited the South Island in 1843, he stated that conditions had improved as a result of the colonisation of New Zealand and the recent bankruptcies of most of the Sydney merchants associated with whaling. The whalers' wages had also increased, since small vessels now visited from Wellington and Akaroa, willing to receive oil and bone in payment. ${ }^{71}$ Nevertheless, the original modus operandi for whaling stations in the southern South Island was responsible for creating the environment within which habitual drunkenness took root.

Addressing drunkenness was important for the minister, as in various instances this practice had led to repercussions detrimental to the peace of the community. In 1841 Watkin recorded the death of a man at Otago, who died after falling down a steep place and into the sea when returning home drunk. ${ }^{72}$ In July 1842, Mr Thomas the Superintendent at Karitāne died of drunkenness, leaving his five children orphaned as his wife had died only two weeks before. ${ }^{73}$ Hence one individual's addiction to the substance could impact the whole family. Most of the European residents were at his burial and Watkin urged them to abandon their drunkenness,

\footnotetext{
${ }^{67}$ Shortland, p. 111.

${ }^{68}$ ibid., p. 113.

${ }^{69}$ Watkin, Journal Vol. 2, 6 September 1841, p. 324.

${ }^{70}$ Shortland, p. 112.

${ }^{71}$ ibid., pp. 112, 113, 107.

${ }^{72}$ Watkin, Journal Vol. 2, 6 March 1841, p. 318.

${ }^{73}$ ibid., 9 and 12 July 1842, p. 334.
} 
reminding them of how, when three boats were wrecked the previous October, six of the eight persons to perish had drowned while drunk. ${ }^{74}$ 'A short time after' Watkin wrote, 'I went down to the store and found a number of them far gone in a state of inebriety'. ${ }^{75}$ Although not everyone heeded Watkin's words, he had instructed them for their own well-being and for that of their families. As drunkenness tied into other moral issues, it was a matter that the minister could not overlook. In September of 1842, Watkin attributed a break in at John Jones' store to love of strong drink. ${ }^{76}$ By denouncing the practice, Watkin encouraged the health of individuals and the stability and peace of the community as a whole.

While James Watkin was the first missionary to set up a mission station in the South Island and to reside there, missionaries from the Church of England and the Roman Catholic Church visited the South Island later in 1840. From the Roman Catholic Church, Fathers Comte and Pezant and Brother Florentin sailed for Akaroa on 27 June 1840, joined later by Bishop Pompallier and Father Tripe. From there Pompallier, Comte and Pezant sailed for Otago in their schooner. ${ }^{77}$ By November, Watkin was aware that a Roman Catholic Priest was two hundred miles away visiting French emigrants at Akaroa, while the Church of England had sent Māori teachers into the South Island. ${ }^{78}$ Despite being located at Ōtaki in the lower North Island, within a few years CMS missionary Octavius Hadfield's converts were to be found as far south as Kawakaputaputa along the southern coast of the South Island. ${ }^{79}$ In December 1842, Hadfield sent out Te Rauparaha's son Katu, christened Tāmihana, and his cousin Henare Mātene (Henry Martyn) Te Whiwhi, to preach the Anglican gospel to Kāi Tahu. ${ }^{80}$ In July 1843, Watkin recorded that Thompson (Tāmihana) had visited the Mission and gave an exhortation in the afternoon while prayers were read by Josiah from Samuel Ironside's

\footnotetext{
74 ibid., 12 July 1842, p. 334; Pratt, The Pioneering Days, p. 74.

${ }^{75}$ Watkin, Journal Vol. 2, 12 July 1842, p. 334.

${ }^{76}$ ibid., 3 September 1842, p. 337.

${ }^{77}$ Margaret E. Major, 'Christian Missions in the South Island in the 1840's' (M. A. thesis, University of Canterbury, 1964), p. 76.

${ }^{78}$ Watkin, Journal Vol. 2, 7 November 1840, p. 310.

${ }^{79}$ Anderson, The Welcome of Strangers, p. 202.

${ }^{80}$ Evison, Te Wai Pounamu, p. 163.
} 
Cloudy Bay circuit. ${ }^{81}$ In late January of 1844, James Watkin was gladly surprised to receive a visit from the Anglican missionary George Selwyn, who was consecrated Bishop of New Zealand in October $1841 .^{82}$ Therefore, it was in the early 1840s that the first three churches to set up missions in New Zealand began serious attempts to spread Christianity to Māori in the South Island.

Baptisms were an initial marker of progress which the missionaries longed to see, ideally signifying that candidates had accepted Christian ideas and practices and would renounce contrary ways. A process generally had to be undertaken before one could receive baptism. Harry Evison stated that:

Under James Watkin the Wesleyan regime for converting the heathen to Christianity was strict. Penitent Maoris were required to renounce their "sins" of violence, profanity, slavery, polygamy, alcohol-drinking, cursing, cannibalism, extra-marital sexual activity, and belief in tapu, muru, utu, and taepo. They had to affirm their belief in Jesus Christ and the Gospels. Then came a trial period when as catechumens they had to prove their diligence and their faith. Only then could they become candidates for baptism as true converts, and the most zealous and dependable could afterwards be appointed mission teachers to convert others to the faith. ${ }^{83}$

The Wesleyan missionaries often held to such requirements because they wanted their baptismal candidates to be truly converted, not just in form, although it remained impossible to know the intents of a person's heart. During Watkin's first two years at Karitāne there were few baptisms and many were of European children. ${ }^{84}$ Thor Wagstrom explained that converts could be few and far between during the initial stages of mission contact, as accepting Christianity could threaten familial and social ties. ${ }^{85}$ One of Watkin's earliest

\footnotetext{
${ }^{81}$ Watkin, Journal Vol. 2, 10 July 1843, p. 351; Thomas A. Pybus, Maori and Missionary: Early Christian Missions in the South Island of New Zealand (Wellington: Reed Publishing, 1954), p. 53.

${ }^{82}$ Andrew Porter, Religion versus empire? British Protestant missionaries and overseas expansion, 1700-1914 (Manchester and New York: Manchester University Press, 2004), p. 159.

${ }^{83}$ Evison, Te Wai Pounamu, p. 155.

${ }^{84}$ Roy Belmer, James Watkin: Pioneer Missionary (Auckland: Wesley Historical Society of New Zealand, 1979), p. 33.

85 Thor Wagstrom, 'Broken Tongues and Foreign Hearts: The Religious Frontier in Early Nineteenth-Century South Africa and New Zealand' in Brock, Peggy (ed.), Indigenous Peoples and Religious Change (Leiden and Boston: Brill, 2005), pp. 67-68.
} 
baptisms took place on 24 January 1841, of Hoani Tokonui a dying man around the age of twenty, who became the first Māori to receive a Christian burial in the area. ${ }^{86}$ Having been on the verge of death, he had little to lose in taking the step and receiving baptism, while Christianity promised eternal blessings after the first death to those who had received Christ.

For the living also, Christianity offered those of the lower ranks the potential for social mobility and they were therefore among the earliest converts. Women, servants, slaves, war captives, refugees, the dying and the physically disabled were among those who potentially had the most to gain and the least to lose from accepting Christianity. ${ }^{87}$ Slavery among Māori however differed much from the trade of African slaves across the Atlantic, and various Māori words for referring to people of low status were translated into the more general English word 'slave'. ${ }^{88}$ Yet war captives are commonly believed to have been among the first Māori converts to Christianity. Petrie stated that: 'A religion that denied the existence of tapu and mana was likely to have greater appeal to those who suffered a loss of those attributes than to those of greatest mana. ${ }^{89}$ Christianity offered an avenue by which those of the lower ranks could go on to take up important roles as teachers in their communities. ${ }^{90}$ While it could threaten the authority of chiefs and the conventional hierarchy, many chiefs also converted. Although some may have more keenly felt the challenge to their authority or been reluctant converts, O’Malley noted that other rangatira saw religious change as an opportunity for enhancing their mana by trade or other means. ${ }^{91}$ Adopting the new faith could provide chiefs with another area within which to exercise leadership, if they went on to become teachers and local preachers. This did not necessarily mean that converts had embraced Christian practices to the degree wished for by the missionary and Watkin longed for his congregants to have more than just head knowledge of Christianity, but also an

\footnotetext{
${ }^{86}$ Watkin, Journal Vol. 2, 25 January 1841, p. 316; Major Albert Rugby Pratt, 'Ninety Years Ago: Diary of the Rev. James Watkin', The Press, 18 July 1931, Alexander Turnbull Library, p. 9.

${ }^{87}$ Wagstrom, pp. 67-68.

${ }^{88}$ Hazel Petrie, 'Decoding the Colours of Rank in Māori Society: What might they tell us about perceptions of war captives?', The Journal of the Polynesian Society, Vol. 120, no. 3, 2011, p. 212.

${ }^{89}$ Petrie, Outcasts of the Gods?, p. 250.

${ }^{90}$ ibid., pp. 250, 249.

${ }^{91}$ O’Malley, pp. 199, 203.
} 
'abhorrence of sin, and thirst for holiness which we expect in real Christians'. ${ }^{92}$ Ballantyne highlighted that missionaries were not in reality identical to the 'confident reformers and potent cultural imperialists' that polished missionary publications made them out to be. ${ }^{93}$ Missionary journals, reports, letters and minutes reveal that missionaries understood their reliance upon Māori patronage and questioned the effectiveness of their own work, having a 'deep awareness that they could never fully control the outcomes of their efforts.' Nevertheless, missionaries still sowed the seed of the gospel hoping that a saving faith might spring up among the hearers, whether it happened sooner or in later years.

Three days after the baptism of Hoani Tokonui, Mere Kauri of Bluff was baptised and married to a whaler James Spencer. ${ }^{95}$ Several more baptisms took place in the following months and in 1843 they began to increase significantly. Watkin also married couples that were previously married in the Māori custom and exhorted European men living with Māori women to enter into Christian marriage, which several couples did. ${ }^{96}$ Angela Wanhalla underlined that candidates were typically baptised before being married and missionaries accepted interracial unions 'where they conformed to monogamous relationships and western understandings of respectability. ${ }^{97}$ Watkin baptised several European-Māori children and by 1844 those of mixed Māori and European descent made up ten percent of the Māori population at Otago and Southland, increasing to twenty-four percent by $1864 .{ }^{98}$ In January 1843, Watkin recorded baptising eight young Māori men who each received the names of prominent figures from the Bible or Wesleyan church. ${ }^{99}$ He noted: 'All to whom I have as yet dispensed the sacrament of baptism can read the Scriptures (would I had my share of the

\footnotetext{
${ }^{92}$ Watkin, Journal Vol. 2, 4 December 1843, p. 359.

${ }^{93}$ Ballantyne, Entanglements of Empire, pp. 255-256.

94 ibid.

${ }^{95}$ Belmer, p. 32; Thomas A. Pybus, 'The Rev. James Watkin and the Otakou Mission', The New Zealand Methodist Times, 18 May 1940, p. 22; Pratt, The Pioneering Days, p. 175.

${ }^{96}$ Watkin, Journal Vol. 2, 19 June, 14 August, 9 September and 16 December 1843, pp. 349-350, 353, $354,359$.

${ }^{97}$ Angela Wanhalla, “"The Natives Uncivilise Me" Missionaries and Interracial Intimacy in Early New Zealand' in Grimshaw, Patricia and May, Andrew (eds.), Indigenous Peoples and Cultural Exchange (Eastbourne: Sussex Academic Press, 2010), p. 33.

${ }^{98}$ Watkin, Journal Vol. 2, 16 December 1843, 1 January and 5 March 1844, pp. 359, 361, 364; Anderson, The Welcome of Strangers, p. 195.

${ }^{99}$ Watkin, Journal Vol. 2, 16 and 23 January 1843, pp. 340, 341.
} 
Testaments) know a good deal about Christian doctrine and practice, are consistent in their conduct. ${ }^{100}$ By mid-1843 baptisms throughout the region had become frequent and Watkin reported that New Zealand was receiving the gospel from end to end. ${ }^{101}$ The growth in baptisms had occurred earlier in the North Island where mission stations were longer established, for example CMS missions at Waimate, Paihia and Kerikeri recorded baptising a combined total of 817 adults and 252 children in $1840 .{ }^{102}$ Olssen suggested that 'weariness of war, the mana of the Bible, and a passion for literacy' fed the growth of Christianity among Māori. ${ }^{103}$ The gospel was being preached across the country and many Māori among both the common and chiefly ranks were beginning to identify with it, as indicated by increasing baptisms.

Many chiefs were among those baptised by the Reverend James Watkin. Spreading the gospel to chiefs was particularly useful for fostering peace due to their influential status in the tribe and authoritative roles in time of conflict; ruling chiefs were responsible for leading in times of war and in times of peace. ${ }^{104}$ Chiefly authority however was not dictatorial but rather dependent upon that which was given to them by their people. ${ }^{105}$ Chiefs could require the sanction of their community in order to initiate actions affecting the entire hapū, such as those for peace or for war. ${ }^{106}$ The mission still benefitted from the conversion of notable chiefs, as their mana helped to ensure that many of their people also joined the Wesleyan faith. ${ }^{107}$ At Karitāne in January 1843 Watkin baptised his first rangatira converts, Haimona Pita (Simon Peter) Mutu and Rawiri (David) Te Maire, along with six others, and they helped to conduct some of the church services. ${ }^{108}$ On 18 June 1843, Māori from Ruapuke Island and Cloudy

\footnotetext{
${ }^{100}$ ibid., 23 January 1843, p. 341.

${ }^{101}$ ibid., 12 June 1843 , p. 349.

102 Judith Binney, 'Christianity and the Maoris to 1840: A Comment', New Zealand Journal of History, Vol. 3, no.2, 1969, p. 158.

${ }^{103}$ Olssen, p. 25.

${ }^{104}$ Te Rangi Hiroa, The Coming of the Maori (Wellington: Maori Purposes Fund Board, 1949), pp. 338, 389.

${ }^{105}$ O’Malley, p. 198.

${ }^{106}$ ibid., p. 209.

${ }^{107}$ Evison, Te Wai Pounamu, p. 164.

${ }^{108}$ ibid., p. 163.
} 
Bay attended the Karitāne service and nineteen males, two females, and one child were baptised. ${ }^{109}$ Among those baptised was the chief Korako, a cousin of chiefs Karetai and Taiaroa, and the chief Te Kāhu. They were given the names John Wesley (Hoani Wetere Korako) and Charles Wesley (Tāre Wetere Te Kāhu) respectively and went on to preach to their own tribe. ${ }^{110}$ Taiaroa and his wife Karorina were later baptised by the Rev. George Stannard, and Karetai's wife and children received baptism. ${ }^{111}$ On 12 December 1843, Watkin travelled south to Ōtākou accompanied by several Māori young men as was usual, and he recorded visiting and conducting several services, baptisms and marriages at Te Ruatitiko (near Harrington Point), Tahakopa (near Te Rauone Beach), Tawhiroko (near Taylor's Point) and Pūrākaunui north of Otago Harbour. ${ }^{112}$ Among those baptised at Tahakopa on 13 December was Te Raki the chief of the Taieri district. ${ }^{113}$ A church had been set up at Te Ruatitiko and the chief Hoani Wetere Korako built a church at his kāika at Tahakopa, holding daily services there and conducting a school. ${ }^{114}$ Services were also held at Tawhiroko village and at Waiparapara (now known as the Spit). ${ }^{115}$ Anderson noted that many leading men in the district were among the converts, including Haereroa and Pōtiki. ${ }^{116}$ Many young chiefs converted to Christianity and this was one of the ways in which Kāi Tahu: 'leaders and their people were already preparing themselves for the changing future of Aotearoa' ${ }^{117}$ The conversion of tribal leaders was a favourable example for their people to accept Christianity likewise, especially when they themselves went on to teach, preach, and run church services and schools.

\footnotetext{
${ }^{109}$ Watkin, Journal Vol. 2, 19 June 1843, p. 349.

${ }^{110}$ Pybus, 'Otakou and the First Christian Mission', p. 4; Pybus, 'The Rev. James Watkin and the Otakou Mission', p. 23.

111 Thomas A. Pybus, 'Heroic Pioneer Workers' (Dunedin: Otago Daily Times print, 1940), Alexander Turnbull Library, pp. 3-4.

${ }^{112}$ Watkin, Journal Vol. 2, 16 December 1843, pp. 359, 360; Pybus, Maori and Missionary, pp. 37, 40.

${ }^{113}$ Pybus, 'The Rev. James Watkin and the Otakou Mission', p. 23.

114 ibid; Pybus, 'Otakou and the First Christian Mission', p. 4.

${ }^{115}$ Pybus, 'Otakou and the First Christian Mission', p. 5; Pybus, Maori and Missionary, p. 40.

${ }^{116}$ Anderson, The Welcome of Strangers, p. 200.

${ }^{117}$ T. M. Ka‘ai, J. C. Moorfield, M. P. J. Reilly, S. Mosley, Ki te Whaiao: An Introduction to Māori Culture and Society (Auckland: Pearson Education New Zealand, 2004), p. 148.
} 
Hōne Tūhawaiki was another prominent chief who saw beneficial aspects to having a missionary. As the leading Kāi Tahu chief in Murihiku (the southern part of the South Island), Tūhawaiki requested a European missionary for his people on Ruapuke Island. ${ }^{118}$ This was a key location, as Watkin wrote that it contained a higher population than anywhere else on the South Island, except possibly Cloudy Bay. ${ }^{119}$ Erik Olssen proposed that Tūhawaiki had:

a three-fold strategy for coping with the new world. First, he encouraged the development of skills appropriate to the emergent world of Pakeha and Maori. Second, he clearly envisaged the peaceful integration of these two worlds on terms acceptable to the Maori. And third, he recognised the importance of Pakeha religion and the power of the Pakeha Atua or God. ${ }^{120}$

A missionary would teach his people these new skills including literacy, a valuable acquirement in light of the increasing Pākehā presence in New Zealand and the prime role of text in their society. Olssen noted that Tūhawaiki: "possibly ascribed to the Pakeha Atua the role of unifying the two peoples. ${ }^{121}$ If so, Tūhawaiki recognised the link between the missionary, their gospel, and the attainment of peace. Peace here referring to the peaceful transition of Māori into the changing world resulting from increased European contact. Ballantyne pointed out that the new generation of Kāi Tahu chiefs were: 'literate, Christian, and adept at navigating the practices and structures of the colonial world'. ${ }^{122}$ The missions supplied them with some of this key knowledge, which better equipped them to adapt to the changes taking place in New Zealand. Not all Māori however remained loyal to the missionaries' form of Christianity in subsequent decades. Allan Davidson stated that increased pressure upon Māori land, way of life and autonomy came to generate a defence of what was theirs, resulting in new religious and political movements including Kinngitanga, Hauhau and Ringatū. ${ }^{123}$ The new belief systems however contained elements of Christianity,

\footnotetext{
${ }^{118}$ Watkin, Journal Vol. 2, 4 and 18 June 1842, pp. 331, 332.

${ }^{119}$ James Watkin, Letter to the Secretaries of the Wesleyan Missions, 5 February 1842, Methodist Missionary Society Records, Reference Number: Micro-163, Reel 21, Hocken Collections, University of Otago, p. 2.

${ }^{120}$ Olssen, p. 25.

${ }^{121}$ ibid.

${ }^{122}$ Tony Ballantyne, 'Paper, Pen, and Print: The Transformation of the Kai Tahu Knowledge Order', Comparative Studies in Society and History, Vol. 53, no. 2, 2011, p. 257.

${ }^{123}$ Allan K. Davidson, Christianity in Aotearoa: A History of Church and Society in New Zealand (Wellington: The New Zealand Education for Ministry Board, 2004), p. 39.
} 
as the former gods could no longer be relied upon in light of the changes taking place. ${ }^{124}$ In May 1844, Tūhawaiki's request for a missionary came to be answered by the arrival of the Reverend Johann Friedrich Heinrich Wohlers, just a few months before Tūhawaiki was to perish when swept overboard off Paparoa point, near Timaru. ${ }^{125}$ Wohlers was from the North German Missionary Society and the Watkins hosted him at Karitāne in 1844 and later at Wellington. At the latter location they discovered that Wohlers had decided to become a missionary after reading a German translation of James Watkin's missionary article concerning Fiji. He chose to settle on Ruapuke Island following the advice of Watkin and his successor Charles Creed. Watkin also later officiated at Wohlers' marriage to Elise Palmer, who he was introduced to by Mrs Eliza Creed. ${ }^{126}$ His case illustrates how missionaries played a key role in the lives of one another, as James Watkin had in relation to Wohlers' occupation, location and later marriage.

Māori teachers played a key role in the spread and maintenance of Christianity in New Zealand. As Peggy Brock has highlighted, while religious change is often triggered by outside agents like missionaries, it needs support from within the community to have an impact. ${ }^{127}$ Further, Māori contributed to the introduction of Christianity into their communities, with southern chiefs such as Tūhawaiki, Karetai and Taiaroa first pressing for a missionary to live in their localities. Once the missionaries arrived, they depended on the continued support and protection of local chiefs for the success of the mission station; for example James Watkin was treated hospitably by Kāti Huirapa chief Kurukuru, who was his closest neighbour. The cooperation of the community was also clearly imperative for the mission to function effectively. Due to possessing a proficient insiders' understanding of their own culture and language, indigenous converts to Christianity had an advantage which enabled them to more usefully minister to their own people. ${ }^{128}$ On 9 January 1842 , Watkin baptised a young man Joseph (Hohepa), who taught Māori at Port Levy, and Watkin noted

\footnotetext{
${ }^{124}$ Binney, p. 154.

${ }^{125}$ Atholl Anderson, 'Tuhawaiki, Hone', from the Dictionary of New Zealand Biography, Te Ara-the Encyclopedia of New Zealand, updated 11 February 2013, available from http://www.TeAra.govt.nz/en/biographies/1t110/tuhawaiki-hone

${ }^{126}$ Pybus, Maori and Missionary, pp. 96, 98; Pratt, The Pioneering Days, pp. 191-193.

${ }^{127}$ Peggy Brock (ed.), Indigenous Peoples and Religious Change (Leiden and Boston: Brill, 2005), pp. 2-3, 7.

${ }^{128}$ Peter Sherlock, 'Missions, Colonialism and the Politics of Agency' in Barry, Amanda et al. (eds.), Evangelists of Empire?: Missionaries in Colonial History (Melbourne: eScholarship Research Centre, 2008), p. 19.
} 
that many had and were learning how to read from him. ${ }^{129}$ A south Canterbury chief Horomona (Solomon) Pōhio was baptised in June 1843 and taught at Foveaux Strait, while Merekihireka Hape, a chief of Ōtākou, received baptism on 10 September 1843 and also went on to preach. ${ }^{130}$ In a visit to Moeraki in late September 1843, Watkin appointed two young men as leaders and baptised nineteen adults and five children. ${ }^{131}$ When the Rev. Creed visited Moeraki the following year he found that Matthias and David, who had been baptised by Watkin, were helping to educate the people alongside the main teacher Hoera (Joel), who had been instructed by the Rev. Ironside. ${ }^{132}$ Watkin set up several Māori teachers among those he had baptised, who held services at various villages in the Ōtākou area, and by 1844 there were twenty-six of them between Moeraki and Stewart Island. ${ }^{133}$ Māori teachers were essential for ensuring that the Wesleyan converts across this expanse were effectively ministered to, carrying out the duties of running church services and schools. It still remained important however for the missionaries to visit the various congregations in their circuit to assist the people and teachers. On 24 February 1844, Watkin set sail intending to reach Ruapuke Island, and ended up stopping by Bloomfield Harbour, Stewart Island and Jacobs River, where he gave advice and books, held services, and conducted several baptisms and marriages. Due to dangerous anchorage they were not able to reach Ruapuke, so Watkin instead sent a parcel to his teacher Solomon stationed there. ${ }^{134}$ By visiting outer areas within their circuit, missionaries could distribute key resources including books and medicine, conduct tasks unique to them such as baptisms and marriages, and generally strengthen the people in Christianity. The missionary and Māori teachers therefore worked in unison to diffuse the gospel, Christian ideas and practices into their communities.

\footnotetext{
${ }^{129}$ Watkin, Journal Vol. 2, 10 January 1842, p. 326; James Watkin, Letter to the Secretaries of the Wesleyan Missions, 5 February 1842, p. 3.

${ }^{130}$ Anderson, The Welcome of Strangers, pp. 200, 202; Evison, Te Wai Pounamu, p.163; Pybus, 'The Rev. James Watkin and the Otakou Mission', p. 23.

${ }^{131}$ Watkin, Journal Vol. 2, 30 September 1843, p. 356; Pratt, 'Ninety Years Ago', 29 August 1931, p. 18.

${ }^{132}$ Charles Creed, Letter to the General Secretaries of the Wesleyan Missions, 28 November 1844, Methodist Missionary Society Records, Reference Number: Micro-163, Reel 22, Hocken Collections, University of Otago, p. 1.

133 Pybus, 'Otakou and the First Christian Mission', p. 2; Anderson, The Welcome of Strangers, p. 202; Pybus, 'The Rev. James Watkin and the Otakou Mission', p. 23; Major Albert Rugby Pratt, 'The Rev. James Watkin: The Pioneer of Christianity in the South Island', The New Zealand Methodist Times, 18 May 1940, p. 26.
}

${ }^{134}$ Watkin, Journal Vol. 2, 29 February, 5 and 6 March 1844, pp. 363, 364. 


\section{Furthering the communication of the gospel through schools}

Aside from direct preaching and church services, commencing schools reinforced the work of spreading the gospel. In the schools, James Watkin taught Māori how to read, write, and of the scriptures and the catechism. Translation work was important for this, so Watkin remained both a student of the language and a teacher. Increasing his own ability in te reo would better enable him to teach it to them in written form. While Māori previously conveyed information through means such as tā moko (traditional Māori tattooing) and carvings or markings on objects such as rock, pounamu (jade), wood, bone and sand, written words communicated the information more directly and literally. ${ }^{135}$ By November 1840 Watkin was writing short prayers and hymns in Māori for the instruction of the people, and by February 1841 he had nearly finished translating the First Catechism into Māori, noting that it would be the means of spreading knowledge among the people. ${ }^{136}$ Teaching Māori literacy and supplying them with Christian literature would further enable Christian ideas to circulate among the community.

Watkin held a school for men and boys in the early morning on weekdays and one for women and girls in the evening, noting that both were: 'well attended for the scant population of the place, all ages and all grades, old, young, chiefs, people, faces furrowed with time as well as with the tattooing instrument. The Priests too are I trust likely to believe. ${ }^{137}$ Watkin started teaching Māori literacy in their own language by writing out alphabets by pen, until he could get assistance from the printing press at the Wesleyan mission station at Māngungu, Hokianga. ${ }^{138}$ William Woon had established the printing press at Hokianga in 1836, one year after William Colenso of the CMS set up the first successful press at the Bay of Islands. ${ }^{139}$ Watkin found the pioneer nature of his work in the southern South Island particularly difficult, writing: 'Laying the foundation is hard work, a missionary who has a precursor knows little of the trouble of beginning a mission, teaching them reading is a hard matter but I am cheered when they can spell a short word without hesitation. How glad I shall be when

\footnotetext{
${ }^{135}$ Jones and Jenkins, p. 9; Ballantyne, 'Paper, Pen, and Print', p. 241.

${ }^{136}$ Watkin, Journal Vol. 2, 21 November 1840 and 15 February 1841, pp. 312, 318.

${ }^{137}$ ibid., 27 November 1840, p. 313.

${ }^{138}$ ibid., 1 August 1840, p. 304.

${ }^{139}$ Ka'ai et al., p. 42.
} 
any of them shall be able to read. ${ }^{140}$ Acquiring the ability to read would remove a key barrier to their ongoing learning. Teaching literacy was a part of teaching the gospel, as once Māori could read independently, they would have the ability to study the scriptures in their own time.

Watkin also organised school classes at Moeraki, where by March 1842 a house was being built to serve as a school and chapel. ${ }^{141}$ Watkin noted that at least one person at Moeraki had learnt to read and write a little from a place further north, being taught by either an instructed Māori, a C.M.S. Catechist, or Māori connected with the Church Missionary Society. ${ }^{142} \mathrm{He}$ remarked: 'It is surprising how prayers, hymns, catechism \& c are being spread through the country by oral communication. Those who can read and write are rather too proud of their acquirements and when out of the direct influence of the Missionary love to set up Teachers on their own account'. ${ }^{143}$ Pratt stated that Watkin established schools from Moeraki in the north to Stewart Island in the south and was effectively a pioneer in organising a system of education there, as Scottish settlers only opened their first school in Dunedin on 24 September 1848. ${ }^{144}$ Watkin was among the first to establish schooling in the area and in March 1844 he recorded visiting and assisting at a school that had just commenced for children of mixed Māori and European decent at Jacobs River (Riverton), which was where John Jones owned another whaling station opposite Rakiura (Stewart Island). ${ }^{145}$ Ballantyne noted that after James Watkin's arrival at Otago, Kāi Tahu communities increasingly encountered texts and paper, including Bibles, prayer books, newspapers, letters and notebooks, in their meetings with Watkin, the Māori teachers and visiting churchmen. ${ }^{146}$ Stevens stated that some Kāi Tahu may have attained knowledge of reading and writing at an earlier stage, citing the example of sealer John Boultbee in 1827 teaching chiefs Karetai and Taiaroa how to write in the sand. However, Stevens noted that Kāi Tahu literacy effectively

\footnotetext{
${ }^{140}$ Watkin, Journal Vol. 2, 14 November 1840, p. 311.

141 ibid., 14 March 1842, p. 330.

142 ibid., 17 January 1842, p. 327.

143 ibid.

${ }^{144}$ Pratt, 'The Rev. James Watkin: The Pioneer', p. 26.

${ }^{145}$ Watkin, Journal Vol. 2, 6 March 1844, p. 364; Shortland, p. 300.

${ }^{146}$ Ballantyne, 'Paper, Pen, and Print', p. 243.
} 
began with the establishment of the Karitāne mission, and a European family arriving at Ōtākou in 1843 found that many Māori could read and write. ${ }^{147}$ When Watkin married several Māori women to European men, the church register showed that while the women could write their own names, the husbands placed only their mark. ${ }^{148}$ Charles Creed also found in 1844 that many at Moeraki could read the New Testament with fluency, crediting the work of Māori teachers there. ${ }^{149}$ While not all Māori could read, more were becoming proficient and Mantell's 1852 survey of the southern districts found that around twenty per cent of Kāi Tahu could read and twelve per cent could write. ${ }^{150}$ Ballantyne observed that, by around 1850, roughly half of the high-ranking Kāi Tahu men could sign their name on land deeds and many more Kāi Tahu likely had some reading skills in Māori, as missionaries emphasised reading and it typically preceded learning to write. ${ }^{151}$ James Watkin was therefore among the first to teach Kāi Tahu literacy in an ongoing way, establishing schools that Māori teachers would carry on and reaching a wide range of people including men and women, young and old.

James Watkin's family also contributed to the operation of the Karitāne mission station. As was commonly the case in missionary journals, James Watkin's entries from New Zealand do not generally mention his wife and children with the exception of their births, baptisms, or when they were in ill health. Two sons were born to Hannah and James Watkin at Karitāne, Joseph Hebblewhite on 22 December 1841 and John Wesley on 29 April 1844, while their youngest son Samuel Ironside was born at Wellington on 17 August 1846 and their youngest daughter Lucy Entwisle was later born in Wellington. ${ }^{152}$ Samuel was named after the Rev. Ironside while their other children had likewise taken the name of family members, close friends or Christian leaders. At Karitāne, Watkin recorded that his wife Hannah Watkin and their two eldest children James Entwisle and William Jackson assisted him in running the

\footnotetext{
${ }^{147}$ Michael J. Stevens, 'Kāi Tahu Writing and Cross-Cultural Communication', Journal of New Zealand Literature, No. 28, Part 2: Special Issue: Cultures of Print in Colonial New Zealand, 2010, p. 133.

${ }^{148}$ Pybus, 'Otakou and the First Christian Mission', p. 3.

${ }^{149}$ Creed, Letter to the General Secretaries of the Wesleyan Missions, 28 November 1844, p. 1.

${ }^{150}$ Anderson, The Welcome of Strangers, p. 215.

${ }^{151}$ Ballantyne, 'Paper, Pen, and Print', pp. 244-245.

${ }^{152}$ Watkin, Journal Vol. 2, 27 December 1841, 29 April 1844, 17 August 1846, pp. 326, 366, 378.
} 
schools. ${ }^{153}$ Students would ask his sons questions relating to grammar to help them learn. ${ }^{154}$ However, Watkin's recurring concern was that his own children would fall behind in their education. It therefore came as a relief when a friend in Australia, W. Hebblewhite, offered to pay for the education of James Entwisle and William Jackson in New South Wales. One day after seeing them off in January 1842, Watkin remarked: 'The sacrifices which a Missionaries wife and Family are obliged to make are not often thought of, but they are not the less for that. May God preserve them from the dangers of the sea. And allow us to meet them again in this world, and $\mathrm{O}$ may we dwell together in a better. ${ }^{155}$ The missionary's family supported the mission work and had to make sacrifices as well. Hannah Watkin's main work involved maintaining the household and teaching. Patricia Grimshaw commented that on a practical level missionary wives played a vital role on the mission station by running mission households, demonstrating gendered ideals and teaching in schools. ${ }^{156}$ Concerning the Māori women at Karitāne, James Watkin noted that they did most of the work, collecting the wood and cooking the food. ${ }^{157}$ Missionary families often had young Māori women help them with household chores, yet this proved harder to secure amidst the smaller Karitāne population. In May 1841, Watkin commented that no female assistance could be found, due to eligible women being partnered with whalers. ${ }^{158}$ Hannah Watkin was therefore kept busy each day undertaking the necessary housework, which allowed James Watkin to concentrate more directly on the mission tasks. She also contributed more directly to the diffusion of Christian teachings and practices among Māori by helping to run the schools. Known to Māori as Mata Wakina (Mother Watkin), Hannah Watkin instructed the women in hygiene, child care, dress, and taught the girls how to sew, wash and iron clothes, and how to cook in the European

\footnotetext{
153 ibid., 27 November 1840, p. 313.

154 ibid., 1 August 1840, p. 304.

${ }^{155}$ Watkin, Journal Vol. 2, 26 January 1842 and 22 February 1873, pp. 328, 593.

${ }^{156}$ Patricia Grimshaw, 'Missions, Colonialism and the Politics of Gender' in Barry, Amanda et al. (eds.), Evangelists of Empire?: Missionaries in Colonial History (Melbourne: eScholarship Research Centre, 2008), p. 5.

${ }^{157}$ Thomas A. Pybus, 'Rev. James Watkin: An Unpublished Letter', Otago Daily Times, 2 June 1939, Alexander Turnbull Library, p. 3.

${ }^{158}$ James Watkin, Letter to the General Secretaries of the Wesleyan Missionary Society, 8 May 1841, Methodist Missionary Society Records, Reference Number: Micro-163, Reel 20, Hocken Collections, University of Otago, p. 1.
} 
way. ${ }^{159}$ Her students included women and girls who travelled from Ōtākou to Karitāne to be taught. ${ }^{160}$ The missionary wife and their older children therefore made a vital contribution to the functioning of the mission station, helping to teach Māori literacy, Christian practices and practical skills.

Books were of crucial importance for assisting the missionary with the teaching work. The first books that Watkin prepared were focused on teaching Māori how to read and once they had acquired that skill, other Christian texts would be of more use to them. In January 1841, printed copies of the first book that Watkin had written arrived and were soon sought after. ${ }^{161}$ Learning to read and to write had become fashionable among northern Māori in the 1830s and early 1840 s and this trend spread southward. ${ }^{162}$ Watkin's small primer for teaching Māori how to read was the first book to be printed in the Kāi Tahu dialect and it was printed in East Sydney, likely because Watkin initially had more contact with Sydney than with the Hokianga mission in the North Island. ${ }^{163}$ Around a quarter of a century before, in 1815 the first New Zealand book had been printed at Sydney for teaching Māori in the CMS mission school at Rangihoua. ${ }^{164}$ By the end of January 1841, Watkin had prepared a second book to be sent off for printing at the Wesleyan mission station at Māngungu, which he received back in December. ${ }^{165}$ Watkin noted that these resources were assets to the school and valuable for teaching reading. ${ }^{166}$ Later that year, he received a few Māori Testaments and hymn books sent by the missionary Ironside, who was stationed at Cloudy Bay in the Cook Strait. ${ }^{167}$ The

\footnotetext{
${ }^{159}$ Pybus, 'The Rev. James Watkin and the Otakou Mission', p. 23; 'A Notable Centenary: Suggested Memorial at Waikouaiti', Otago Daily Times, 13 October 1920, p. 6.

${ }^{160}$ Pybus, 'Otakou and the First Christian Mission', p. 3.

${ }^{161}$ Watkin, Journal Vol. 2, 18 January 1841, p. 316.

162 Jones and Jenkins, p. 200.

${ }^{163}$ Pratt, 'Ninety Years Ago', 23 July 1931, p. 10; Paul W. Fairclough, Copy of Extracts from letters to Rev Samuel Ironside, Cloudy Bay \& Wellington, from Rev James Watkin, Waikouaiti 1 June 1841, Catalogue No. MS208, Methodist Church of New Zealand Archives, 1902; Pratt, The Pioneering Days, pp. 113-114; Watkin, Letter to the Secretaries of the WMS, 18 June 1840, p. 1.

${ }^{164}$ Jones and Jenkins, pp. 119, 118.

${ }^{165}$ Watkin, Journal Vol. 2, 30 January and 13 December 1841, pp. 316, 326.

166 ibid., 13 December 1841, p. 326.

${ }^{167}$ Pratt, 'Ninety Years Ago', 23 July 1931, p. 10.
} 
demand for books seemed to increase around the same time that baptisms were increasing, in 1843.

However, delayed communication with Wellington caused shortages in books and writing equipment such as slates and pencils, slowing down the teaching work. Watkin likened his situation to that of Israelite bondmen having to make bricks without straw. ${ }^{168}$ In April 1843 a supply of books arrived, including New Testaments from the British and Foreign Bible Society. Although the supply was relatively small for Watkin's circuit, it was still gratefully received. ${ }^{169}$ The New Testaments were treasured by their possessors, who eagerly acquired them. When Watkin held a Bible class in May 1843 he was pleased with the answers given and questions made, and he reported that Māori held an evening service among themselves on Sunday. ${ }^{170}$ He noted that Māori were attentively drinking in the word, and he was pleased to see that those who had Bibles and could read were reading along as he carried out the lessons. Explaining his routine for conducting the services on Sunday, Watkin wrote: 'I seldom deliver what is called a sermon but attempt expositions of a Chapter or Paragraph, this I consider more profitable for them. In the forenoon I generally remark upon both Lessons and conclude with that part of the Liturgy which follows. In the Afternoon a chapter is generally read and expounded. ${ }^{171}$ There was a clear linkage between learning to read at the schools and then reading the Bible at the church services, with the schools playing a key role in furthering the spread of the gospel by enabling Māori to read the Bible and Christian texts.

The Bible became a new subject of interest, a valued and sought after possession. Watkin remarked: 'They have generally bags or little baskets of a size sufficient to contain The Testament and Hymn Book slung round the neck and occupying the situation erewhile occupied by the powder flask and cartridge box. ${ }^{172}$ The Bible was replacing the bullet as an object of greatest worth; an item encouraging peace surpassed those introduced weapons of destruction. As Ballantyne stated, the ultimate object of the missionary was to translate the

\footnotetext{
${ }^{168}$ Watkin, Journal Vol. 2, 25 April 1843, p. 344.

${ }^{169}$ ibid., 29 April 1843, p. 344.

${ }^{170}$ ibid., 8 and 15 May 1843, p. 346.

${ }^{171}$ ibid., 22 May 1843, p. 347.

172 ibid.
} 
Bible into te reo Māori and create strong communities of Māori Christians. ${ }^{173}$ Watkin’s students frequently asked him what words and phrases meant, repeating what they had learnt in order to retain it. ${ }^{174}$ They were eager to increase in their knowledge of the Bible and literacy, and being in possession of their own New Testaments appears to have done much to encourage this.

Watkin could never have enough Bibles and books as the demand for them was ongoing. A deficiency in books and especially New Testaments had begun to be an issue again by midJune 1843, so the arrival of a case of Testaments in mid-September was gladly welcomed. The people remained anxious to attain books and those who had money would willingly pay what they could, but Watkin found that most could only offer potatoes and firewood in exchange. Watkin noted:

Already I have had applicants from seven, ten, and twenty miles, and let me have a book, let me have a book has almost stunned me and seriously annoyed my poor sick wife. Some who had one wanted to purchase another as a reserve for when the one in use shall have become old or illegible. Let me have one for my wife, my brother, my sister my boy or girl as the case might be has been often urged. Some who cannot read have applied and upon my intimating that a book in such cases would be of little use, I am met with. We will learn, we will learn. And I believe they will. Never did such a precious case reach this place before. Cases of muskets, cases of articles equally if not so immediately fatal have arrived, cases of clothing very useful and necessary, but this, this is the good thing, the better the best thing. ${ }^{175}$

The desire for books and the Bible in te reo Māori remained strong, and the increase and anticipated increase of Māori literacy was adding to the demand. In late October 1843, Watkin visited Wellington for three weeks hoping to learn about the District Meeting of the New Zealand Wesleyan Mission and to acquire supplies, especially books. There he was encouraged to see other Wesleyan missionaries for the first time in over three years, however his aim of attaining books was only partly fulfilled as he found few available. ${ }^{176}$ The Bible,

\footnotetext{
${ }^{173}$ Tony Ballantyne, Entanglements of Empire, p. 254.

${ }^{174}$ Watkin, Journal Vol. 2, 22 May 1843, p. 347.

175 ibid., 16 September 1843, pp. 354-355.

${ }^{176}$ ibid., 12 October and 20 November 1843, pp. 357, 358.
} 
whose teachings were the basis upon which Christian missionaries encouraged peace along with other moral reforms, remained a book in demand.

Māori came to express their Christianity by utilising newly acquired literacy skills. In 1843, Watkin found a message on his pulpit board written to him from Haimona Peter, who he had baptised at Karitāne in January that year. ${ }^{177}$ Watkin recorded it as reading:

To Miti Watakina, O my friend, my love to you; My mind is glad in my Lord and Saviour; My soul is glad. Amen. My evil is gone, and I am seeking to my Saviour Jesus Christ. O his goodness to me is great. I. Simon Peter Mutu. ${ }^{178}$

Māori could express their faith through writing to the missionary who had first taught them about Christianity and literacy. Ballantyne summarised that the texts Māori gave back to missionaries included letters asking for an explanation of scripture, requests for missionaries to visit, to establish a school, or for items such as books, Bibles, paper, slates, pencils and pens, to inquire after the missionary and their family, to discuss spiritual struggles, or to announce their own transformation and embrace of the gospel. ${ }^{179}$ Having acquired literacy in the context of learning from the missionary and studying Christian texts, Māori continued to write on such subjects by letter. They were therefore able to seek clarity for, discuss and confirm their Christianity through writing. Anderson noted that as Kāi Tahu became literate they commenced writing letters to one another, to family and friends in the North Island, and to government officials and the Queen. In the absence of paper, writing was scratched onto slate or flax leaves. ${ }^{180}$

By teaching literacy to Māori, the missionaries helped to provide a peaceful avenue by which Māori could interact with the government to express their grievances. At Karitāne on 30 July 1843, Watkin baptised Tiramōrehu a chief and tohunga (expert, priest, learned man) from

\footnotetext{
177 ibid., 3 October 1843, p. 357; Evison, Te Wai Pounamu, p. 163.

${ }^{178}$ James Watkin, Letter to the Secretaries of the Wesleyan Missions - Journal Extracts, January 1844, Methodist Missionary Society Records, Reference Number: Micro-163, Reel 21, Hocken Collections, University of Otago, p. 9.

${ }^{179}$ Ballantyne, Entanglements of Empire, p. 256.

${ }^{180}$ Anderson, The Welcome of Strangers, p. 200.
} 
Moeraki, who adopted the name Matiaha after the apostle Matthias. ${ }^{181}$ On 22 October 1849 , Tiramōrehu wrote the first formal Kāi Tahu complaint over South Island land purchases, in the form of a letter to Edward John Eyre, the lieutenant governor of the New Munster province of New Zealand which included the South Island. ${ }^{182}$ Having consented to land sales by signing Kemp's Deed the previous year, Tiramōrehu felt a responsibility to hold the Crown to account. He wrote that the lands allocated to them were insufficient, and his initiatives were the beginning markers of Te Kerēme or the Claim, by which Kāi Tahu sought redress from the Crown for failing to provide the land and resources promised in land purchase negotiations between 1844 and $1863 .{ }^{183}$ Tiramōrehu was also involved in writing and signing petitions to the Queen and to Parliament in subsequent decades. ${ }^{184}$ Te Kerēme was eventually settled with the passing of the Ngāi Tahu Claims Settlement Act into law on 29 September $1998 .{ }^{185}$ Claudia Orange notes that this settlement contained Crown and forestry land, title to certain valued sites and reserves, statutory representation on conservation bodies, and a formal apology. ${ }^{186}$ It is possible that Tiramōrehu first acquired literacy outside of Watkin's mission, as in 1842 Watkin noted that at least one person at Moeraki had learned a little literacy from someone further north that may have had links to the CMS. ${ }^{187}$ However if Tiramōrehu did not gain the majority of his literacy skills from Watkin's mission schools, engaging with the mission would still have had the effect of enhancing them. Tiramōrehu was working as one of Watkin's teachers at Moeraki by 1844, thus helping others to acquire literacy skills and to learn about Christianity. ${ }^{188}$ Petrie noted that many tribal leaders used scribes, who were likely teachers and catechists that had been taught at the mission schools, to communicate in writing. ${ }^{189}$ Mission schools contributed to

\footnotetext{
${ }^{181}$ Harry C. Evison, 'Tiramorehu, Matiaha', from the Dictionary of New Zealand Biography, Te Ara - the Encyclopedia of New Zealand, updated 30 October 2012, available from: http://www.TeAra.govt.nz/en/biographies/1t100/tiramorehu-matiaha; Evison, Te Wai Pounamu, pp. 163-164, xvii.

${ }^{182}$ Evison, 'Tiramorehu, Matiaha'.

${ }^{183}$ O’Regan, p. 78.

${ }^{184}$ Ballantyne, 'Paper, Pen, and Print', pp. 254-255.

${ }^{185}$ O'Regan, p. 167.

${ }^{186}$ Claudia Orange, The Treaty of Waitangi, 2nd ed. (Wellington: Bridget Williams Books, 2011), p. 256.

${ }^{187}$ Watkin, Journal Vol. 2, 17 January 1842, p. 327.

188 ibid., 20 January 1844, p. 362.

${ }^{189}$ Petrie, Outcasts of the Gods?, p. 247.
} 
the spread of literacy among Māori, which enabled them to peacefully engage with the Crown through writing and petitions.

Missionary views on colonisation remained complicated while they played a role in both opposing and aiding the process. Their main opposition to it came on the grounds of Māori welfare and the progress of Christianity among them. In 1840, WMS Secretary the Reverend John Beecham was examined by a Select Committee on New Zealand. Concerning the colonisation of New Zealand, Beecham explained:

It would perhaps be fair for me to say that we look upon the subject rather as a missionary society, as a religious body, concerned for the welfare of the natives; and all history, and all past experience, show that colonization has so uniformly been injurious to the interests of the natives, that we cannot look upon colonization with anything like satisfaction. ${ }^{190}$

As Andrew Porter stated, the examples given by South Africa, the West Indies, New South Wales, New Zealand and the Pacific evidenced how uncontrolled white expansion could put indigenous societies and missionary activity at risk. ${ }^{191}$ Similar sentiments were expressed by the Lay Secretary of the CMS Dandeson Coates a few years before. ${ }^{192}$ Coates had recommended leaving New Zealand to the missionaries for fifty more years, by which point he believed that the indigenous people would have become civilised through European agency, yet still have been able to preserve their race, national independence and sovereignty. ${ }^{193}$

As the number of settlers in New Zealand increased however, the need for an authority over its inhabitants came to be felt, in order to restrain lawlessness. James Watkin believed that New Zealand becoming a colony was beneficial for Māori, as they were thereby British subjects with equal rights to those who had oppressed them. ${ }^{194}$ Yet he also expressed concern

\footnotetext{
${ }^{190}$ Report from the Select Committee appointed to Inquire into the Statements contained in the Petition of the Merchants, Bankers, and Shipowners of the City of London, (Presented 22d May 1840,) respecting the Colonization of New Zealand; together with the Minutes of Evidence taken before them, and an Appendix and Index. (London: House of Commons, 1840), p. 93.

${ }^{191}$ Porter, Religion versus empire?, p. 123.

${ }^{192}$ Hilary M. Carey, God's Empire: Religion and Colonialism in the British World, c.1801-1908 (Cambridge: Cambridge University Press, 2011), p. 323.

193 ibid., p. 326.

${ }^{194}$ Watkin, Letter to the Secretaries of the Wesleyan Missions, 30 September 1841, p. 2.
} 
about the future repercussions that Māori would face as a result of the foreigners increasing activity in the country. Claudia Orange noted that most of the missionaries opposed organised colonisation, particularly the New Zealand Association's plans; however they supported government intervention to control the existing settlements and to restrain the arrival of more settlers. ${ }^{195}$ In April 1844, New Zealand Company surveyors under Frederick Tuckett arrived at Otago to seek out land for the proposed New Edinburgh settlement. ${ }^{196}$ Watkin anticipated that the new settlement would add to both the comfort and hindrance of the missionary, commenting:

I fear however that the formation of a settlement will tend to divert the minds of the natives from the best things. In the other settlements I hear it has been the case to a great extent. Talk about colonization as a means of promoting Xy [Christianity] forsooth! The thing is preposterous, it never has tended to that end that I have ever read [or] ever heard of. ${ }^{197}$

Watkin therefore held ambivalent views on the colonisation of New Zealand; while it could provide the sound structures of law and order conducive to a peaceful society, it also proved likely to divert Māori away from accepting Christianity and to thereby weaken the progress of the mission.

The increasing tide of colonisation proved unavoidable and the missionary presence may have helped to ease this process. On 31 July 1844, Kāi Tahu sold the 200,000 hectares Otago block to the New Zealand Company for $£ 2,400$; twenty-three of the twenty-five Otago chiefs that sold their land were Watkin's Wesleyan converts. ${ }^{198}$ Having accepted Christianity from the Wesleyan mission, Māori met twice a day for worship and to seek God's blessing on the negotiations. ${ }^{199}$ Pratt noted that the efforts of missionaries Watkin and Creed helped to create the conditions which made acquiring and peacefully occupying the land possible. ${ }^{200}$ In continuation of this thought, Pybus stated that the sale which took place at Koputai (Port

\footnotetext{
${ }^{195}$ Orange, p. 35.

${ }^{196}$ Watkin, Journal Vol. 2, 22 April 1844, p. 365.

${ }^{197}$ ibid., 4 and 17 June 1844, p. 367.

${ }^{198}$ W. A. Taylor, Lore and History of the South Island Maori (Christchurch: Bascands Limited, 1952), p. 130; Evison, Te Wai Pounamu, p. 206; Anderson, The Welcome of Strangers, p. 206.

${ }^{199}$ Pratt, The Pioneering Days, p. 200.

${ }^{200}$ ibid., p. 57.
} 
Chalmers) was a peaceable gathering without bloodshed or bartering for guns or powder because Māori had been Christianised, many as a result of the ministry of Watkin and Creed. ${ }^{201}$ Whereas where firearms were in demand, muskets and gunpowder had often been requested as payment for supplies and land. ${ }^{202}$ Roy Belmer added that James Watkin was: 'the man who made possible white settlement with the good will of the Maori people at a time when North Island Maoris were being torn apart by past and pending Maori wars. Let it never be forgotten that here there was no Maori War. ${ }^{203}$ James Watkin's ministrations had been instrumental in converting the chiefs, and the influence of Christianity upon them contributed to the land being peacefully sold without contentions at the time. Subsequent grievances were diplomatically expressed as Kāi Tahu came to peacefully engage with settler politicians, which contrasted with those in the north that rejected the Crown's authority. ${ }^{204}$

Other factors likely contributed to this peace as well, for example Watkin considered the Māori inhabitants around that area in particular to be docile. ${ }^{205}$ Travelling with Tuckett's surveyors in 1844, David Monro also commented that Māori resident at Karitāne were 'a very well disposed, inoffensive set of people'. ${ }^{206}$ However the converted chiefs trusted the missionaries, and if they advised them to sell, this would have been taken into account in the final decision. Aware of land sale conflicts at Wairau, chiefs Tūhawaiki and Taiaroa insisted that the agreement at Otago should clearly outline village cultivations, burial grounds and reserves as remaining in Māori possession. ${ }^{207}$ There were also contentions over whether a tenth of the land sold would be held in trust for the future benefit of Kāi Tahu. ${ }^{208}$ The Waitangi Tribunal's 1991 Ngai Tahu Land Report stated that they were not entitled to tenths under the Otago Purchase, although the Crown was found to have breached the Treaty

\footnotetext{
${ }^{201}$ Pybus, 'Otakou and the First Christian Mission', p. 5.

${ }^{202}$ Samuel G. G. Ritchie, “Of Red War and Little Else': European Responses to Indigenous Violence in the Tasman World, c.1769-1850s' (Doctoral thesis, Victoria University of Wellington, 2013), pp. 166-167; Olssen, p. 20.

${ }^{203}$ Belmer, p. 38.

${ }^{204}$ Ballantyne, 'Paper, Pen, and Print', p. 256.

${ }^{205}$ Watkin, Journal Vol. 2, 16 May 1840 and 11 May 1844, pp. 297, 366.

${ }^{206}$ Monro, p. 241.

${ }^{207}$ Orange, p. 115.

${ }^{208}$ Taylor, p. 130; Evison, Te Wai Pounamu, pp. 206-207.
} 
resulting in serious economic loss for Kāi Tahu. ${ }^{209}$ In an 1848 letter to the General Secretaries of the WMS, Watkin commented that Christianity had made colonisation possible, yet colonisation had brought both good and evil to Māori. The evils to which he referred here were moral issues such as card playing, drinking and non-attendance at church. While New Zealand Company settlers were taking or receiving the credit for civilising Māori, Watkin wrote in the context of trying to highlight the missionaries' part in things. ${ }^{210}$ Nevertheless, James Watkin's letters and journal entries showed a constant awareness of both the benefits and drawbacks of colonisation upon Māori. This reflected a wider theme, as Hilary Carey noted that the attitude of churches to emigration and colonisation remained ambivalent throughout the nineteenth century. ${ }^{211}$ Missionary views on colonisation were also mixed, varying in accordance with the context and developments over time.

Watkin was appointed to Port Nicholson (Wellington) and on 19 April 1844 his replacement arrived, the Reverend Charles Creed with his wife Eliza and family, assigned to Otago by the WMS. $^{212}$ They arrived on the schooner Deborah which also carried New Zealand Company surveyors and the missionary Johann Wohlers. ${ }^{213}$ Creed was to labour there for nine years, succeeded by the Rev. William Kirk from 1854, then the Rev. George Stannard from 1857 until 1859, and then the Rev. J. F. Reimenschneider from 1862 until his death in $1866 .{ }^{214}$ On arrival at Karitāne, Charles Creed was pleased with the work that Watkin had accomplished at the isolated mission station, writing to the WMS secretaries in May:

The Natives here may be classed with those of the older Stations; they would do no discredit to those in the northern island either in Scriptural knowledge or general information. The unwearied exertions of Bro. Watkin are truly praiseworthy. May the seed which he has sown,

\footnotetext{
${ }^{209}$ Evison, Te Wai Pounamu, p. 490.

${ }^{210}$ James Watkin, Letter to the General Secretaries of the Wesleyan Missions, 22 February 1848, Methodist Missionary Society Records, Reference Number: Micro-163, Reel 23, Hocken Collections, University of Otago, pp. 2-3.

${ }^{211}$ Carey, p. 307.

${ }^{212}$ Watkin, Journal Vol. 2, 9 November 1842 and 20 April 1844, pp. 339, 365; Major Albert Rugby Pratt, 'Rev. Charles Creed and Early Otago', The New Zealand Methodist Times, 18 May 1940, p. 29.

${ }^{213}$ Evison, Te Wai Pounamu, p. 200.

214 Thomas A. Pybus, Otakou, A Story of Far-off Days (Auckland: Wesley Historical Society of New Zealand, 1941), pp. 9-11; Pybus, 'Heroic Pioneer Workers', p. 3.
} 
spring up and bring forth an abundant harvest, and may many of these reclaimed New Zealanders be the crown of his rejoicing in the day of the Lord. ${ }^{215}$

Around the same time, David Monro likewise observed that Māori at Karitāne had been instructed in the Christian religion, reading and writing, as well under James Watkin as at any other part of New Zealand that he had visited. Monro considered the progress made by Māori, in the short time since the mission had been established, as a sign of their aptitude and eagerness for instruction. ${ }^{216}$ Watkin had successfully worked to communicate Christianity and literacy to Māori. Monro noted that Watkin's labours extended from Moeraki, thirty miles north of Karitāne, to the Bluff one hundred and thirty miles to the south. ${ }^{217}$ Watkin recorded in his journal on 4 June 1844, concerning his time at Karitāne, that he had baptised a total of 258 persons including some children, married thirty-seven couples, and there were then about 227 meeting in class and more than twenty leaders and preachers. ${ }^{218}$ He married two more couples on the day of his departure, bringing that count up to thirty-nine. ${ }^{219}$ Evison highlighted that James Watkin converted more Māori in his first three years than the CMS's mission at the Bay of Islands had in its first fifteen, possibly because the CMS had first aimed to civilise Māori while the WMS focused on converting them to Christianity. ${ }^{220}$ The mission influence emanating from the north also likely had an influence, with Māori travelling southward and spreading the gospel. The number of Christian converts would continue to increase and Anderson noted that by 1850 most Kāi Tahu were Christian. ${ }^{221}$

Watkin closed his Karitāne ministry on 23 June 1844, preaching to a large congregation and baptising six people from Ruapuke Island and a child of one of the church leaders, while Charles Creed baptised Watkin's youngest new-born son John Wesley. James Watkin's parting hopes were that his labours had not been in vain and that God would bless the people

\footnotetext{
${ }^{215}$ Charles Creed, Letter to the Secretaries of the Wesleyan Missions, 30 May 1844, Methodist Missionary Society Records, Reference Number: Micro-163, Reel 22, Hocken Collections, University of Otago, p. 3. 
there. ${ }^{222}$ Around 1844, local Māori renamed Hikaroroa 'Mount Watkin' after James Watkin and today this mountain located near the Waikouaiti River bears both names. ${ }^{223}$ Having resided at Karitāne for four years, Watkin and his family had become solid members of its community. He visited and prayed with the sick and dying, and many Māori proved receptive to his message. Watkin reported that local Māori believed that change had taken place for the better since his arrival. In June 1843 Watkin wrote: 'In conversation with Korako last night, he told me that my coming had put an end to Cannibalism, murder and other evils formerly frequent. ${ }^{224}$ Korako was an old chief at Karitāne who did not fully commit to Christianity until a few years later, being baptised by Charles Creed in 1848 and adopting the name Te Wakena (Watkin) while his wife Kupukupu chose the name Mata Wakina (Mother Watkin). ${ }^{225}$ Through the missionary’s sustained efforts, living nearby Māori at Karitāne, visiting individuals and communities, conducting services, schools, baptisms and marriages, James Watkin had laboured to spread Christian teachings and practices among the people. The missionary influence had an effect for peace in the community, affecting the behaviour of others even if they did not convert to Christianity themselves.

\section{Continuation of the mission work at Wellington}

The Watkin family arrived at Port Nicholson on 29 June 1844, to labour alongside Samuel Ironside and his wife Sarah. James Watkin had been appointed Superintendent of Wellington and for much of the time he was also Chairman of the Southern District. ${ }^{226}$ Just five years before, the first known Christian service at Te Aro in Wellington had been held by the Revs. John H. Bumby and John Hobbs at the request of Ngā Māhanga missionary Minarapa Rangihatuake, which serves as another example of the role Māori had in introducing Christianity into their communities. ${ }^{227}$ Minarapa Te Rangihatuake had converted to

\footnotetext{
${ }^{222}$ Watkin, Journal Vol. 2, 24 June 1844, p. 367.

${ }^{223}$ Pratt, The Pioneering Days, p. 22.

${ }^{224}$ Watkin, Journal Vol. 2, 5 June 1843, p. 348.

225 ibid., 5 July 1842, p. 334; Pybus, Maori and Missionary, p. 93.

${ }^{226}$ Ironside, p. 734.

${ }^{227}$ Arthur Leslie Olsson, Raupo Chapel to Multi-Racial Community 1839 to 2005: A Chronology with some Early Recollections marking the $125^{\text {th }}$ Anniversary of the Opening of the Wesley Church in Taranaki Street, Wellington (Wellington: Philip Garside Publishing, 2005), p. 8; John H. Roberts, 'Rangihatuake, Minarapa', from the Dictionary of New Zealand Biography, Te Ara - the Encyclopedia of New Zealand, updated 30 October 2012, available from http://www.TeAra.govt.nz/en/biographies/1r1/rangihatuake-minarapa
} 
Christianity as a captive in the Bay of Islands and many released captives at that time carried the Christian teachings they had learnt back to their communities further southward, by this means helping to pave the way for the missionaries that followed. ${ }^{228}$ By the start of August 1843, Samuel Ironside had shifted from Cloudy Bay to the Wellington circuit as a consequence of the Wairau affray. ${ }^{229}$ That occurrence took place on 17 June 1843, when there was a clash between New Zealand Company surveyors and Ngāti Toa chiefs over disputed land at Wairau, resulting in the deaths of twenty-two Europeans and four Māori. The District Meeting consequently appointed Ironside to Port Nicholson, proximate to Cloudy Bay, for the purpose of maintaining good relations between missionaries and Māori in the wake of the Wairau affray. ${ }^{230}$ Later when there was a risk of Ironside being shifted to another station, some of Ironside's congregation drew up a petition requesting that he remain at Wellington, citing how he 'had been instrumental in allaying much angry feeling and in restoring to harmony much that was in confusion before. ${ }^{231}$ As tensions, mainly over land, persisted between settlers and Māori, missionaries were perceived as having a role to play in maintaining peaceable relations within the community.

Watkin undertook his customary duties, preaching to various English and Māori congregations within the Wellington circuit and conducting baptisms. Watkin and Ironside each conducted two Māori and two English services on Sunday, five more during the week, and ran a Māori school from $5 \mathrm{pm}$ to $6: 30 \mathrm{pm}$ daily. ${ }^{232}$ Having become accustomed to the Māori dialect spoken in the southern South Island, Watkin now adjusted his use of the language to maximise effective communication with Māori at Wellington. ${ }^{233}$ In December 1845, Watkin arranged for the construction of a small chapel to double as a School House at

\footnotetext{
${ }^{228}$ Petrie, Outcasts of the Gods?, pp. 247, 248.

${ }^{229}$ Wesley A. Chambers, Samuel Ironside in New Zealand 1839-1858 (Auckland: Ray Richards Publisher, 1982), p. 147.

${ }^{230}$ Samuel Ironside, Letter to the Secretaries of the Wesleyan Missions, 21 November 1843, Methodist Missionary Society Records, Reference Number: Micro-163, Reel 21, Hocken Collections, University of Otago, p. 2.

${ }^{231}$ Major Albert Rugby Pratt, 'Rev. Samuel Ironside: A Star of the Maoriland Morning', The New Zealand Methodist Times, 18 May 1940, pp. 24-25.

${ }^{232}$ Chambers, p. 164.

${ }^{233}$ Watkin, Journal Vol. 2, 8 July 1844, p. 368.
} 
Porirua Road, which he was able to preach in by January $1847 .{ }^{234}$ Where there is a gap in James Watkin's journal entries from November 1847 until 1855, the Ironsides left Wellington for Nelson while John Aldred and later Charles Creed joined the Wellington circuit. On 16 October 1848, the Wesleyan church on Manners street was destroyed from an earthquake; although James Watkin was in Auckland at the time, it remained with him to direct the rebuild effort when he returned. ${ }^{235}$ The church was again damaged when another serious earthquake struck on 23 February 1855; however it was repaired and reopened on 13 July that year. ${ }^{236}$ Watkin therefore helped to maintain the physical structure of the churches, as well as the spiritual by ministering to various congregations throughout the circuit. He continued to teach and encourage both settlers and Māori in the ways of Christianity, believing that following these principles would best ensure peace within the community.

Watkin continued to be involved in initiatives aimed at maintaining the peace of the community and preventing its disruption. In September 1848, Watkin played an instrumental role in the formation of a branch of the Evangelical Alliance in Wellington. ${ }^{237}$ In September 1849, Watkin forwarded to WMS Secretary John Beecham a copy of a petition sent to Earl Grey the Secretary of State for the Colonies. This petition was signed by more than 250 members and friends of the Evangelical Alliance in Wellington, expressing opposition to a proposal of sending convicts out to the New Zealand colony. ${ }^{238}$ After the public learned of this proposal in April 1849, both Māori and Europeans were against it, and in an $8^{\text {th }}$ of May despatch the New Zealand Governor Sir George Grey strongly stated the harms of introducing the convicts. ${ }^{239}$ The Wellington Evangelical Alliance's petition noted that the signees were engaged in promoting the moral and religious welfare of settlers and Māori, and they believed that introducing the convicts to New Zealand would prove injurious to the community, neutralising the good efforts that they had exerted over the years. ${ }^{240}$ They

\footnotetext{
${ }^{234}$ ibid., 9 December 1845 and 26 January 1847, pp. 376, 381.

${ }^{235}$ Olsson, pp. 44, 11; Chambers, pp. 182-183.

${ }^{236}$ Olsson, p. 11.

${ }^{237}$ Chambers, p. 176.

${ }^{238}$ James Watkin, Letter to Dr. Beecham, 26 September 1849, Methodist Missionary Society Records, Reference Number: Micro-163, Reel 24, Hocken Collections, University of Otago, p. 2.

${ }^{239}$ J. Howard Wallace, Manual of New Zealand History (Wellington: Edwards \& Green, 1886), p. 30.

${ }^{240}$ Watkin, Letter to Dr. Beecham, 26 September 1849, pp. 2, 4.
} 
opposed the measure on various grounds, including that the criminals would face difficulties due to being stigmatised, making them more likely to return to crime. They wrote that this would set a negative example for Māori, as had fugitives that occasionally came to New Zealand from neighbouring colonies, while increased expenditure on protecting property and administering justice would drain public resources. ${ }^{241}$ These arguments were set down with the intent of having the strongest possible effect to deter the Secretary of State from pursuing such a course of action. In seeking the peace and well-being of the community, James Watkin and fellow Protestant ministers were among those to sign this petition.

Their sentiments were shared by the public at large, who were against the idea of more convicts being sent to New Zealand, considering this detrimental to the character and progress of the young colony. In July and September of 1849, Governor Grey forwarded likeminded petitions from Māori residing in the regions of Auckland and the Cook Strait. ${ }^{242}$ Noting that European missionaries had witnessed most of the signatures on these two petitions, Gregory Picker stated that the missionary influence among the Māori community was significant, although Māori petitions and protests likely reflected the genuine will of the community. ${ }^{243}$ In signing these petitions, possibly with the encouragement of missionaries, Māori engaged with issues that would affect the future of the colony. By signing and encouraging others to sign petitions against the proposed transportation of convicts to New Zealand, missionaries sought to preserve peace within the community and to counter potential threats to it. On 26 November 1849, Earl Grey stated in a despatch that the Queen would not be advised to send any convicts to New Zealand. ${ }^{244}$ Early the following year, local newspapers published Earl Grey's despatch to the Governor, stating that no specific plans for sending the convicts existed and that they would not be sent. ${ }^{245}$ The aim of the various petitions and widespread public remonstrance was effectively achieved.

\footnotetext{
${ }^{241}$ ibid., pp. 2-4.

${ }^{242}$ Gregory Picker, 'A State of Infancy: The Anti-transport Movement in New Zealand, 1848-1852', New Zealand Journal of History, Vol. 34, no. 2, 2000, p. 227.

${ }^{243}$ ibid.

${ }^{244}$ Wallace, p. 30.

${ }^{245}$ Picker, p. 232.
} 


\section{Instances of direct intervention}

James Watkin also encouraged peace in the community by more directly intervening in some cases to prevent violence. On 4 March 1841, a sailing accident occurred by which the Karitāne chief Kurukuru drowned, along with his wife, daughter, brother, nephew, brother-inlaw and three others. ${ }^{246}$ By 1844 , Koroko Tupepe and Te Wakaemi were recorded as Karitāne's main chiefs by Edward Shortland. ${ }^{247}$ After the drowning, Watkin described Karitāne as 'a place of weeping' and rumours began to circulate that a human sacrifice would be made to the manes of the deceased. ${ }^{248}$ A slave was sometimes killed after the death of a high chief, the aim being for his spirit to accompany the spirit of his master and serve him in his final journey. ${ }^{249}$ If a woman died her slave might also be sacrificed to go with her, although the victims were not always war captives. ${ }^{250}$ Petrie stated that the purpose behind the practice was not entirely clear, while in one case a woman captive managed to avoid being sacrificed on two occasions, by hiding until the funeral ceremonies ended. Others however resigned themselves to their fate. ${ }^{251}$ Hearing that the slave's life was at risk, Watkin recorded:

$M^{\underline{r}}$ [W. G.] Thomas $M^{r}$ Jones Superintendent here and I went to the people and told them what we had heard, I stated that such a procedure would be very wicked, an aggravation of the evil under which we were suffering, and moreover contrary to and would be punished by British Law. I told them the man that should murder the slave named to me would render himself obnoxious to the punishment of death by hanging. Koroko [Kurukuru's father] assured me that nothing of the kind should be done. Another said we have heard you say "Thou shalt not kill" and we are afraid of doing what we used to do. ${ }^{252}$

In this case James Watkin fostered the peace by actively intervening to ensure that no innocent blood was shed, helping to preserve and honour the life of the slave. His preaching

\footnotetext{
${ }^{246}$ Watkin, Journal Vol. 2, 6 March 1841, pp. 319-320.

${ }^{247}$ Anderson, The Welcome of Strangers, p. 188.

${ }^{248}$ Watkin, Journal Vol. 2, 6 March 1841, p. 320.

${ }^{249}$ Hiroa, p. 429.

${ }^{250}$ Petrie, Outcasts of the Gods?, pp. 138-139.

251 ibid.

${ }^{252}$ Watkin, Journal Vol. 2, 6 March 1841, p. 320; Pratt, The Pioneering Days, p. 90.
} 
tied into the peaceful outcome, as learning about the Ten Commandments had already discouraged some from undertaking this practice. Petrie noted that by the 1830s, war captives were less likely to be sacrificed to accompany their deceased captors to the afterlife. ${ }^{253}$ While Jewish merchant Joel Polack suggested that, as a result of expanded trade with Europeans, it was in their economic interests to retain slaves for labour, missionaries attributed the ending of this practice and the improved treatment of slaves to the spread of the gospel. ${ }^{254}$

Watkin sought to preserve life in its various forms, recording in July 1841 that he was warning a Māori woman who had committed infanticide that she would be penalised by the British Law, although the seat of justice was distant and difficult to access. ${ }^{255}$ Watkin's main aim was to deter these practices from taking place. As with other crimes, Ritchie pointed out that infanticide occurred in every society and for similar reasons, although in Britain it was more concealed in contrast to 'the more visible forms of Māori infanticide encountered by European settlers, ${ }^{256}$ Watkin did not provide many details on this account, however the focus here is that by condemning the practice Watkin was denouncing violence against infants. In this way he encouraged physical peace for all segments of society, whether it was the young that could not defend themselves or the slave that occupied the lower ranks in the community. In July 1842, Watkin recording having had to interfere in a case of violence perpetrated by a white man against a Māori boy. ${ }^{257}$ By intervening in cases where crimes were perpetrated against vulnerable persons in society, James Watkin assumed the role of a peacemaker, seeking to subdue violence and unjust occurrences within the community. Watkin actively encouraged peace among the people by discouraging violence and promoting the value of every life.

Watkin sought to foster peaceful relations between Māori and Europeans in the community, evidencing by his conduct that he viewed both on equal terms under Christianity. In late June

\footnotetext{
${ }^{253}$ Petrie, Outcasts of the Gods?, p. 222.

254 ibid., pp. 48, 221, 222.

${ }^{255}$ Watkin, Journal Vol. 2, 6 July 1841, p. 322.

${ }^{256}$ Ritchie, pp. 106-108.

${ }^{257}$ Watkin, Journal Vol. 2, 23 July 1842, p. 335.
} 
of 1842, Mrs Thomas the wife of the Superintendent at Karitāne passed away. ${ }^{258}$ A few days after her interment, controversy arose when the Rev. Watkin buried a deceased Māori woman named Tautaki near Mrs Thomas' grave in the Christian burial ground. ${ }^{259}$ In his journal Watkin recorded, incidentally on the $4^{\text {th }}$ of July:

this has given huge offence as I am told to some of the most Christian whites, who are highly indignant at such a blow against white superiority being struck for according to their notions superiority exists after death as well as during life, an opinion from which I am a most sincere dissenter, and gave some of my reasons for the same to my white congregation in the evening, by which they might learn that I thought if superiority exists that it belongs to the natives and not to them. Some of the offended are Americans, who with their vaunted declaration of rights staring them in the face "All men are free and equal["], I have ever found to be the most virulent enemies of natives in whatever country it has been my lot to live, a disposition in which the Australians as far as I have seen them here appear to sympathize. The natives of this country are with all their faults and vices better in every respect than the creatures who calumniate them. The aborigines of this country need protection. ${ }^{260}$

James Watkin viewed Māori and Pākehā Christians as equally deserving of burial in those grounds, considering Christianity as a unifying force which should ultimately supersede racial prejudice. He did not sympathise with those opposing his actions in this matter, even though they likewise identified themselves as Christians. Allan Davidson highlighted that the minority of Pākehā had a humanitarian concern for Māori welfare at the time, while much prejudice, racism and ignorance of Māori culture persisted. ${ }^{261}$ Missionaries however could be linked to the humanitarianism emanating from England and were often their overseas informants. Porter notes that following the abolition of slavery as an institution throughout most of the British Empire in 1833, humanitarians began to focus on the plight of indigenous peoples perceived to be suffering from the consequences of European expansion. ${ }^{262}$ Many came to see the need for an authority, notably British control, in New Zealand in order to

\footnotetext{
${ }^{258}$ ibid., 4, 9 and 12 July 1842, pp. 333, 334.

${ }^{259}$ Pybus, Maori and Missionary, p. 18.

${ }^{260}$ Watkin, Journal Vol. 2, 4 July 1842, p. 333.

${ }^{261}$ Davidson, p. 40.

${ }^{262}$ Porter, Religion versus empire?, p. 139.
} 
regulate contact and rein in the lawlessness and conflicts that were arising in its absence. ${ }^{263}$ Watkin was of this camp, having a strong preference for British over French control in New Zealand, and believing that the operation of British Law could help to protect Māori and to suppress the enormities practiced by the Europeans, there being many ex-convicts among them. ${ }^{264}$ Watkin countered the influence of these Europeans through his preaching and actions, promoting a relationship of peace between Māori and foreigners rather than one of striving for dominance.

James Watkin encouraged Europeans to interact peacefully with Māori, in contrast to practicing violent or untoward behaviour. While Evison remarked that there were probably just as many disputes among Europeans as there were between Kāi Tahu and Europeans, the missionary showed a particular concern for the latter category. ${ }^{265}$ In a May 1841 letter to the WMS secretaries, Watkin commented that Māori men were treated poorly by the men on whaling stations, who were themselves of differing races. ${ }^{266}$ Writing to the WMS four months later, he stated:

The wickedness of the Christians so called is abounding and flagrant[,] great as it is, it would be greater were not a Missionary resident, and what they fear more, a Magistrate tho' the latter is at a considerable distance. On several occasions I have threatened to apply to him, and it has had the tendency to restrain the parties from the excesses which called forth my threats. English law will soon I trust bring into order the lawless persons which are scattered over the land. ${ }^{267}$

The Police Magistrate Charles Robinson was located at Akaroa. Due to the distance from official law enforcement officers, Watkin sought to deter lawlessness by threatening to and actually informing the legal authorities in the colony. While Wesleyan missionaries aimed to exert a moral influence, they appealed to the secular authorities in matters of law enforcement. ${ }^{268}$ Shortland recorded that in the North Island, Māori recognised the

\footnotetext{
263 ibid., p. 142.

${ }^{264}$ Watkin, Journal Vol. 2, 7 October 1840, p. 308.

${ }^{265}$ Evison, Te Wai Pounamu, p. 90.

${ }^{266}$ Watkin, Letter to the General Secretaries of the WMS, 8 May 1841, p. 2.

${ }^{267}$ Watkin, Letter to the Secretaries of the Wesleyan Missions, 30 September 1841, p. 2.

${ }^{268}$ Report from the Select Committee, p. 92.
} 
Government's right to apply English law to cases involving both Māori and Europeans; however it was refused in cases involving Māori only, except perhaps by the side seeking retribution. ${ }^{269}$ It was a similar case in the South Island, with John Christie recording in 1880 that Māori around Waikouaiti settled internal disputes among themselves, while more serious matters could be referred to the Hawksbury Resident Magistrate. ${ }^{270}$ Ritchie noted that the Native Exemption Ordinance of 1844 'formalised the previously informal policy of ignoring internecine Māori 'crime': unless iwi requested assistance, the police magistrate would not generally intervene in issues not affecting Pākehā. ${ }^{271}$ While Māori generally preferred to settle their own conflicts, though there were growing exceptions to this, they had a greater acceptance of British law in cases between themselves and Europeans. ${ }^{272}$ By warning foreigners that he could apply to the magistrate against them, Watkin sought to deter them from continuing in disorderly conduct. Hereby he encouraged them to regulate their behaviour, so as not to jeopardise the peace of the community.

Watkin believed that race relations had improved as a result of the missionary presence. In July 1842, the aged Karitāne chief Korako told Watkin of a past incident in which a whaler had dashed boiling water upon him, causing burns, when he had been searching their hut for a stolen blanket, and Watkin postulated that Māori were treated better since the arrival of the missionary. ${ }^{273}$ Improved conduct could be attributed to both the missionary influence and the enhanced presence of the law after New Zealand came under British dominion in 1840, first as a part of New South Wales and then as a separate British colony. To a degree missionaries encouraged this second factor as well, perceiving that New Zealand would benefit by having British authority to restrain conflicts arising from lawlessness. Consequently, the protection of Britain was best received in areas where missionaries were the most active. ${ }^{274}$ Lieutenant Governor Hobson also appointed CMS missionary George Clarke as Protector of the Aborigines in April 1840, a somewhat contradictory role requiring that Clarke both guard

\footnotetext{
${ }^{269}$ Shortland, p. 134.

${ }^{270}$ Christie, p. 53.

${ }^{271}$ Ritchie, p. 218.

${ }^{272}$ Orange, pp. 105-106.

${ }^{273}$ Watkin, Journal Vol. 2, 5 July 1842, p. 334.

${ }^{274}$ Orange, p. 90.
} 
Māori welfare and be the government's main negotiator for purchasing their land. ${ }^{275}$ In any case, government officials could be far-off while the missionary was closer at hand to the foreigners near Karitāne, and therefore more immediately able to influence them and to encourage moral behaviour. In the more serious cases, Watkin wielded the threat of reporting misconduct to law enforcement officials, which helped to limit unlawful conduct among the Europeans.

${ }^{275}$ ibid., p. 93. 


\section{Chapter 2: Fostering peace in times of war}

Chapter two will consider how the missionary James Watkin contributed to the fostering of peace in times of warfare. Decreases in the Māori population, as a result of warfare and introduced diseases, made the attainment of peace appear all the more indispensable. In times of conflict, missionaries could assume the role of mediators between Māori and Europeans in order to assist in the process of making peace. James Watkin also encouraged chiefs to adopt Christianity and this could become a point held in common by Māori of differing tribes, facilitating intertribal peace. The missionary helped to unite Wesleyan Māori together under a shared faith by visiting Māori in each area of the circuit and holding church gatherings which brought them together. These gatherings provided an occasion for the fostering of peace between those in attendance.

\section{Māori population decreases}

The peace offered by Christianity was appealing in light of Māori population decreases in the nineteenth century. It is relevant to discuss this here, as war had caused many of the fatalities among Māori; the missionary message was therefore pertinent as it discouraged warfare and encouraged peaceful conduct which would help to preserve the Māori population into the future. Watkin learned about recent conflicts that had taken place and he regarded Tūhawaiki, known by the English name Bloody Jack, as the main chief in the South Island and Te Rauparaha as their mortal enemy. ${ }^{1}$ Tūhawaiki had signed the Treaty of Waitangi in June 1840 and Europeans viewed him as the preeminent chief of Kāi Tahu, despite his failure to gain unanimous approval for the position among chiefs at Akaroa in $1842 .{ }^{2}$ Watkin encountered Tūhawaiki in October 1840, when the chief visited with four large boats full of his people and a body guard of soldiers wearing old soldiers' jackets acquired in Sydney. ${ }^{3}$ Tūhawaiki adopted European styled clothing, housing and sea vessels, and Olssen suggested that he recognised how the presence of Pākehā could provide added protection against Te

\footnotetext{
${ }^{1}$ James Watkin, Journal of James Watkin, Vol. 2, 1840-1882, Reference Number: fMS-255, Alexander Turnbull Library, 23 June 1840, pp. 302, 303.

${ }^{2}$ Atholl Anderson, The Welcome of Strangers: An ethnohistory of Maori A.D. 1650-1850 (Dunedin: University of Otago Press, 1998), pp. 94, 97.

${ }^{3}$ Watkin, Journal Vol. 2, 19 October 1840, p. 309.
} 
Rauparaha. ${ }^{4}$ However the European presence alone was not guaranteed to enhance peace between iwi. Watkin was informed of the 1830 Elizabeth incident by the chief Takatahara, who had evaded death by refusing to board a Sydney captain's ship which had been concealing Te Rauparaha and a number of his people, set to attack Kāi Tahu at Akaroa. ${ }^{5}$ In this raid many Kāi Tahu were captured or killed and settlements around Akaroa Harbour destroyed; trust in Europeans was also shaken as a result of Captain Stewart's role in transporting and concealing the attacking party. ${ }^{6}$ The following year, Ngāti Toa returned bringing destruction upon Kaiapoi and Ōnawe; yet by the summer of 1831 to 1832 Kāi Tahu had driven them out of their territory. ${ }^{7}$ Watkin commented: 'The slaughter of the New Zealanders of this Island by Taraupala [Te Rauparaha] has been immense. ${ }^{8}$ However, the Christianity taught by the missionaries offered an alternative to the warfare that was still fresh in the minds of the people, with its resulting destruction, displacement and loss of life. Petrie underlined how Christianity provided leaders with a convenient reason: 'for putting the brakes on warfare that had reached unprecedented levels in extent and killing power. ${ }^{9}$ One of the CMS's Christian converts was Te Rauparaha's son Tāmihana, who visited the South Island teaching the gospel to Kāi Tahu people who were once considered enemies. Watkin highlighted how Christianity had brought peace between the former foes. ${ }^{10}$ According to Tāmihana, he and his cousin Te Whiwhi visited Port Cooper, Akaroa, Moeraki, Ōtākou and Ruapuke Island; when Kāi Tahu asked if Te Rauparaha would attack them again, Tāmihana responded that he had come to bring an end to the warfare. ${ }^{11}$ Instead of leading in combat, Tāmihana chose to become a leader of peace through the instrumentality of the gospel.

\footnotetext{
${ }^{4}$ Erik Olssen, A History of Otago (Dunedin: John McIndoe, 1984), p. 23.

${ }^{5}$ Watkin, Journal Vol. 2, 1 September 1840, pp. 305-306.

${ }^{6}$ Hana O’Regan, Ko Tahu, Ko Au: Kāi Tahu Tribal Identity (Christchurch: Horomaka Publishing, 2001), p. 79.

7 ibid.

${ }^{8}$ Watkin, Journal Vol. 2, 1 September 1840, p. 306.

${ }^{9}$ Hazel Petrie, Outcasts of the Gods? The Struggle over Slavery in Māori New Zealand (Auckland: Auckland University Press, 2015), pp. 244-245.

${ }^{10}$ Watkin, Journal Vol. 2, 10 July 1843, p. 351.

${ }^{11}$ Harry C. Evison, Te Wai Pounamu - The Greenstone Island: A History of the Southern Maori during the European Colonization of New Zealand (Wellington and Christchurch: Aoraki Press, 1993), p. 174.
} 
The release of prisoners helped to enhance the role of Christianity in fostering intertribal peace. In the upper North Island, captives learnt about Christianity from the missions and when released they returned southward to their hapu in the 1830s, dispersing knowledge of Christian teachings on peace and the missionaries' role in securing peace between rival iwi. ${ }^{12}$ The southward return of Kāi Tahu prisoners accompanied by some northern partners in 1839 also contributed to more peaceable relations with Ngāti Toa. ${ }^{13}$ One of the traditional methods for attaining peace deals was through the orchestrated marriages of high-ranking women, which facilitated the formation of alliances. ${ }^{14}$ Claims to kinship through an inter-tribal marriage were used to prevent tribes from warring, while a defeated tribe could give their chief's daughter to the leader of the opposing party in order to bring about reconciliation. ${ }^{15}$ Once children were born from these political marriages, the binding between iwi was strengthened as these children belonged to both sides and were living symbols and reminders of the peace agreement. Their families became takawaenga or mediators and were respected for their role in inter-tribal relationships. ${ }^{16}$ Alternatively, valuable taonga (a highly prized object) such as heirlooms, an item of greenstone or weapons of great mana, could be exchanged between parties to visibly symbolise the peace agreement. ${ }^{17}$ Therefore, Christianity added to these traditional forms of peace-making, encouraging forgiveness over revenge and peace over the continuation of warfare between feuding tribes.

The Māori population in the nineteenth century had also been afflicted as a result of early encounters with Europeans. Measles, tuberculosis, typhoid and venereal diseases were transmitted to New Zealand following the contact period. ${ }^{18}$ After visiting Pūrākaunui north of Otago Harbour in 1843, Watkin stated that the population there had greatly decreased, here

\footnotetext{
${ }^{12}$ Samuel G. G. Ritchie, "Of Red War and Little Else': European Responses to Indigenous Violence in the Tasman World, c.1769-1850s' (Doctoral thesis, Victoria University of Wellington, 2013), p. 179.

${ }^{13}$ Anderson, The Welcome of Strangers, p. 202.

${ }^{14}$ Angela Wanhalla, “"The Natives Uncivilise Me” Missionaries and Interracial Intimacy in Early New Zealand' in Grimshaw, Patricia and May, Andrew (eds.), Indigenous Peoples and Cultural Exchange (Eastbourne: Sussex Academic Press, 2010), p. 26.

${ }^{15}$ Te Rangi Hiroa, The Coming of the Maori (Wellington: Maori Purposes Fund Board, 1949), pp. 367, 400, 402.

${ }^{16}$ Hirini Moko Mead, Tikanga Māori: Living by Māori Values (Wellington: Huia, 2003), pp. 169-170.

17 ibid., pp. 168, 170.

${ }^{18}$ Hiroa, p. 409.
} 
attributing it to the measles and other things brought by foreigners. ${ }^{19}$ Māori may have suffered high mortality from measles as a result of lacking resistance to the new disease, and also from the practice of immersing the sufferer in water to wash away tapu, which could add complications like pneumonia to the original illness. ${ }^{20}$ At Ōtākou also, whalers attributed a decrease among Māori to lives lost in a measles epidemic, which had taken place a few years before, and from the wars against Te Rauparaha. ${ }^{21}$ An 1835 measles epidemic at Ōtākou could be traced back to Ruapuke Island, where men had gathered in the summer of 1834 to 1835 for a campaign against Te Rauparaha. Many of them caught the disease when a ship arrived from Sydney carrying infected southern Māori and three hundred were said to have subsequently died from measles. ${ }^{22}$ Tuberculosis caused fatalities among both Māori and Europeans, while influenza afflicted the Māori population after spreading to Ōtākou in 1836 via Jones' schooner the Sydney Packet, though it was no longer as destructive by $1848 .{ }^{23}$ Around 1848 to 1849 there was another outbreak of measles among Māori. ${ }^{24}$ Evison estimated that European-introduced epidemics in the 1830s halved the Kāi Tahu population, causing more fatalities than Te Rauparaha's invasion, while the resulting labour loss brought an immediate decline in the production of crops and material for European trade. ${ }^{25}$ In the first half of the nineteenth century, the Kāi Tahu population was believed to have been greatly diminished by warfare and disease.

James Watkin also believed that the Māori population was negatively impacted by transitory relationships occurring between Māori females and European men. In July 1842, Watkin stated that many of the girls involved had not even been through puberty yet, while one foreigner 'who considers himself respectable has latterly buried his third concubine'. He continued: 'My hopes of the preservation of these tribes are faint indeed. Disease prevails,

\footnotetext{
${ }^{19}$ Watkin, Journal Vol. 2, 29 June 1843, p. 350.

${ }^{20}$ Hiroa, p. 409.

${ }^{21}$ Edward Shortland, The Southern Districts of New Zealand; A Journal, with Passing Notices of the Customs of the Aborigines (Christchurch: Caper Press, 1974), p. 39.

${ }^{22}$ Anderson, The Welcome of Strangers, p. 193.

${ }^{23}$ Evison, Te Wai Pounamu, p. 86; Anderson, The Welcome of Strangers, pp. 193, 194.

${ }^{24}$ John Christie, History of Waikouaiti, $2^{\text {nd }}$ edition (Christchurch: Christchurch Press Company Limited, 1929), pp. $91,143$.

${ }^{25}$ Evison, Te Wai Pounamu, pp. 85, 86; O’Regan, p. 79.
} 
deaths are much more common than births, and the inequality of the sexes is rendered greater by the females being given to Foreigners, many of whom die' ${ }^{26}$ This practice of Māori females engaging with European men in either temporary or substandard relationships tied into disease and in this way contributed to decreasing numbers. Petrie noted that missionaries were concerned with the salvation of the soul and redemption in Christ, which tied into moral redemption including being brought out of the sex trade and immoral relationships. ${ }^{27}$ Although Angela Wanhalla stated that Watkin failed to acknowledge female agency in these relationships, it is in certain ways indicated in his journal; for example in September 1843 Watkin married two couples, noting that these Māori women had given their English partners the ultimatum of marriage or separation. ${ }^{28}$ Here the agency of the women in securing the marriages was made evident. The missionary to Ruapuke Island, Johannes Wohlers, similarly noted in 1846 that Māori women wanted to be officially married, as a reflection of their religion but also possibly to prevent the men from leaving again. Wohlers commented that those who did not wish to permanently reside there shunned marriage. ${ }^{29}$ In 1844 , Frederick Tuckett estimated that two-thirds of Māori women of childbearing age, between Banks Peninsula and Riverton, were living with Europeans. ${ }^{30}$ While this would contribute to a decline in the number of children that had two Māori parents, many children of mixed Māori and European descent were born in the 1830s and 1840s. ${ }^{31}$ They evidently counted as members of the tribe, with descent being the prime element to identifying as Kāi Tahu. ${ }^{32}$ Still, the impression persisted among many that the Māori population was at risk, and the adoption of practices taught by the missionaries could help to minimise malady related deaths. For example, learning about hygiene at the mission stations would work for the prevention and cure of illness. European men and Māori women committing to stable relationships and marriage, instead of transitory relationships, could also help to decrease the spread of venereal disease.

\footnotetext{
${ }^{26}$ Watkin, Journal Vol. 2, 23 July 1842, p. 335.

${ }^{27}$ Petrie, Outcasts of the Gods?, p. 239.

${ }^{28}$ Wanhalla, p. 27; Watkin, Journal Vol. 2, 9 September 1843, p. 354.

${ }^{29}$ Wanhalla, p. 28.

${ }^{30}$ Anderson, The Welcome of Strangers, p. 194.

${ }^{31}$ ibid., pp. 196, 195.

${ }^{32}$ O'Regan, p. 53.
} 
The onslaught of colonisation made peace appear all the more indispensable. Watkin noted in July 1840: 'The race is now so low in number that I fear it will not rally, but that others will come and take away their place and nation. ${ }^{33}$ A decreasing Māori population would render them more vulnerable to the effects of mass migration from Europe into the country. Newly arrived settlers would need land and Māori would have to grapple with how much to sell and retain, while underhand methods for attaining that land, cultural differences, unfulfilled promises and other misunderstandings stirred up tensions and bitterness. Anderson noted that after the sale of Kemp's block in 1848, Kāi Tahu became largely confined to living on reserves in Canterbury and north Otago. ${ }^{34}$ Māori trade with Europeans also declined as Kāi Tahu lost access to many past commodities and European farming and fishing became dominant. ${ }^{35}$ Not everyone however believed that the Māori race would become extinct; Shortland anticipated that their population would increase as a result of the effects of Christianity and civilisation. ${ }^{36}$ He primarily attributed the decrease of inhabitants in certain areas to Māori migrating to locations where they could work for Europeans and attain goods from them. For example, many Māori had migrated to Karitāne and other locations with whaling stations; many Māori had likewise moved to Port Nicholson when settlers first arrived there, dispersing once other settlements arose. ${ }^{37}$ There was no unanimous consensus on the decreasing Māori population and uncertainty exists over what the Kāi Tahu population numbered before colonisation. It was difficult to accurately calculate due to their large territory, which was in parts hard to access, and their frequent movements. ${ }^{38}$ In 1841 Watkin believed that there were fewer than one thousand Māori from Foveaux Strait to Banks Peninsula. ${ }^{39}$ Anderson commented that the population most likely did not exceed between 1,500-2,000 in the 1840s and 1850s, noting that Shortland numbered the Kāi Tahu population

\footnotetext{
${ }^{33}$ Watkin, Journal Vol. 2, 13 July 1840, p. 303.

${ }^{34}$ Anderson, The Welcome of Strangers, p. 152.

35 ibid., pp. 129-130.

${ }^{36}$ Shortland, pp. 41, 42.

${ }^{37}$ ibid., pp. 40, 51-52.

${ }^{38}$ Anderson, The Welcome of Strangers, p. 186.

${ }^{39}$ Paul W. Fairclough, Copy of Extracts from letters to Rev Samuel Ironside, Cloudy Bay \& Wellington, from Rev James Watkin, Waikouaiti 1 June 1841, Catalogue No. MS208, Methodist Church of New Zealand Archives, 1902.
} 
at 1,923 while Halswell gave an estimate of 1,774 in $1844 .{ }^{40}$ Yet at the time it was still common to believe that the Māori race was at risk and Watkin feared for their extinction. ${ }^{41}$ Colonisation related conflicts threatened to further impact the population, so attaining peace seemed crucial for the preservation of Māori and the welfare of both races. It would have appeared wise to pursue peace for the benefit of Māori and Europeans, instead of afflicting both populations through war. Christianity offered an alternative to the warfare and an avenue for attaining peace.

\section{Missionary mediation}

Missionaries were able to foster peace between groups through their mediation. James Watkin recorded in his journal on 13 March 1841: 'This place has been one of considerable excitement during the week, and but for the presence of a Missionary might have been one of war and bloodshed, as it was a sham fight served the place of a real one, which I thought sufficiently horrible. ${ }^{42}$ It is possible that no serious harm was intended by the visiting party, although Watkin's journal entry at least indicates that he believed there was potential for violence. Pratt explained that a group of northern canoes had arrived in Waikouaiti Bay with a taua or war party and James Watkin had advanced into the water to make his protest, thereby preventing physical conflict from taking place. Opposing groups instead faced each other on the beach, a haka (ceremonial war dance) was performed, and at the end muskets were fired into the swamp to signify the restoration of goodwill. After partaking in discussion and a feast of peace, they parted on good terms and the missionary was given an enthusiastic ovation. ${ }^{43}$ The two parties previously at variance were clearly pleased with this peaceable outcome and the Rev. Watkin's initial role in encouraging it. Therefore, the peace achieved was not so much imposed from without as desired from within the parties. As Petrie stated: 'Although peace may have been desired, it needed to be obtained without loss of mana, so declaring peace through missionary agency could be an effective face-saving/manapreserving approach. ${ }^{44}$ Maintaining mana was important for chiefs who were in themselves

\footnotetext{
${ }^{40}$ Anderson, The Welcome of Strangers, p. 187.

${ }^{41}$ Watkin, Journal Vol. 2, 13 March 1841, p. 320.

42 ibid.

${ }^{43}$ M. A. Rugby Pratt, The Pioneering Days of Southern Maoriland (London: Epworth Press, 1932), pp. 94-95.

${ }^{44}$ Petrie, Outcasts of the Gods?, p. 253.
} 
emblematic of the mana of their whole hapū, and there remained a risk of being seen as weak for showing compassion, although they could otherwise gain respect for it. ${ }^{45}$ Ritchie also discussed how mana and missionaries could impact the formation of peace in relation to the Musket Wars. Once muskets were evenly distributed, rival iwi were no longer advantaged by having them and began to desire peace. However an irregular adoption of peace would result in a loss of mana, therefore missionary intervention was sought out as a means by which both sides could attain peace while maintaining mana. ${ }^{46}$ In James Watkin's case, it is not recorded whether his intervention was first sought out by Māori at Karitāne, although someone would have informed him of what was taking place. Through the missionary's initiative, the contending parties were able to attain peace and the restoration of good relations, without suffering harm or loss of mana.

Missionaries also sought to facilitate peace between Māori and Europeans when they assumed the role of mediators. In the unsettled times, they tried to prevent the outbreak of conflict or to otherwise allay it. When Watkin was stationed at Karitāne in August of 1843, he received a letter from the Rev. Samuel Ironside informing him that the Wairau affray had taken place. The origins of the dispute came from Nelson settlers wanting to occupy the seemingly unused Wairau Valley, which Ngāti Toa claimed as theirs by right of conquest. Instead of waiting for a decision from the Land Claims Commissioner William Spain, as Māori wished, New Zealand Company surveyors set up survey-poles and built huts with local resources; Ngāti Toa chiefs Te Rauparaha and Te Rangihaeata had these huts burnt down in response. ${ }^{47}$ On 17 June 1843, men from the New Zealand Company and government officials from the Nelson settlement, led by Arthur Wakefield of the New Zealand Company, went to arrest Te Rauparaha and a scuffle broke out. Some of the English opened fire and Te Rongopamamao a wife of Te Rangihaeata was shot, escalating the battle. Twenty-two Europeans including Wakefield ended up surrendering and were killed to avenge for the deaths of Te Rangihaeata's wife and another man, there being an estimated four Māori fatalities in total. ${ }^{48}$ At that time Ironside was still stationed at Cloudy Bay, nearby Wairau.

\footnotetext{
${ }^{45}$ Mead, p. 6.

${ }^{46}$ Ritchie, pp. 185-186.

${ }^{47}$ Evison, Te Wai Pounamu, p. 165; Claudia Orange, The Treaty of Waitangi, 2nd ed. (Wellington: Bridget Williams Books, 2011), p. 115.

${ }^{48}$ Evison, Te Wai Pounamu, pp. 165-166.
} 
Watkin anticipated that the missionaries would receive criticism and complained that the New Zealand Association servants had done their best to neutralise the missionary influence. ${ }^{49}$ The New Zealand Company disfavoured some of the missionaries because they had opposed some of the Company's land dealings with Māori. ${ }^{50}$ However prior to the Wairau tragedy, Ironside wrote to Captain Arthur Wakefield in a letter delivered on the $12^{\text {th }}$ of June, warning that the situation needed to be handled diplomatically or there could be serious repercussions. Consequently, Captain Wakefield wanted to return to Nelson but his opinion was contrasted by that of a surveyor Mr Thompson and Crown Prosecutor $\mathrm{Mr}$ Richardson, who were subsequently among those to perish. ${ }^{51}$

Ironside had been aware of growing discontent, later asserting in a letter to the Secretary of the WMS: 'There was a murder committed in Cloudy Bay on Dec-20th 1842, upon a native woman [Rangihaua Kuika] \& her child... and it was in consequence of the acquittal of the man [Richard] Cook that the natives were so ready to quarrel with the surveyors at Wairau., ${ }^{, 52}$ Carrying a Bible in hand, Rawiri Kingi Puaha, who assisted Ironside, had also urged both sides to keep the peace when tensions were high. ${ }^{53}$ The closest missionary to the scene had therefore attempted to prevent the disaster that followed. In its wake, Ironside travelled to the site of the attack and buried the deceased with the consent of Te Rauparaha and Te Rangihaeata. ${ }^{54}$ Pratt stated that the affray would have been avoided altogether if they had heeded Ironside's advice. ${ }^{55}$ Missionaries laboured to avert calamities, though the results of their efforts could vary depending on whether key actors chose to cooperate with their recommendations or otherwise. Once stationed at Wellington, James Watkin reported in

\footnotetext{
${ }^{49}$ Watkin, Journal Vol. 2, 12 August 1843, p. 353.

${ }^{50}$ Thomas A. Pybus, Maori and Missionary: Early Christian Missions in the South Island of New Zealand (Wellington: Reed Publishing, 1954), p. 32.

${ }^{51}$ Pratt, The Pioneering Days, pp. 185, 186.

${ }^{52}$ Samuel Ironside, Letter to the Rev. John Beecham, 1 August 1844, Methodist Missionary Society Records, Reference Number: Micro-163, Reel 22, Hocken Collections, University of Otago, p. 3; Lowther Broad, The Jubilee History of Nelson: From 1842 to 1892 (Nelson: Bond and Finney, and Co, 1892), pp. 45-46. In his letter to Beecham, Samuel Ironside noted that he had been an interpreter at Richard Cook's trial, which was held in April 1843 at Wellington.

${ }^{53}$ Pratt, The Pioneering Days, p. 186.

${ }^{54}$ Major Albert Rugby Pratt, 'Rev. Samuel Ironside: A Star of the Maoriland Morning', The New Zealand Methodist Times, 18 May 1940, p. 24; Pratt, The Pioneering Days, p. 186.

${ }^{55}$ Pratt, 'Rev. Samuel Ironside’, p. 24.
} 
February 1845 that, following discord in Wanganui between local inhabitants of both races and Māori from Taupo, some compromise was achieved and the invading party sent home. He attributed this decent outcome to the interference of the missionaries and the Deputy Governor. ${ }^{56}$ Missionaries assisted as mediators in time of conflict, encouraging rival parties to pursue agreeable courses of action.

North Island conflicts involving Māori and settlers became a regular feature in James Watkin's journal entries from 1845 to 1847 . In February 1845, Watkin heard of troubles at Wanganui, Nelson, Whangarei and the Bay of Islands. Governor Robert FitzRoy, who Watkin believed should not have earlier withdrawn the Militia Bill which could have deterred war, was now talking of "sanguinary punishment". Closer by, the Governor had told Māori at the Hutt, who were said to be unjustly occupying English land, to remove and they were meeting at Kāpiti to decide where they would go. ${ }^{57}$ At the end of March 1845, Watkin heard of the war and bloodshed that had taken place at Kororāreka in the Bay of Islands, resulting in the deaths of soldiers, Māori and sailors. ${ }^{58}$ Governor Sir George Grey, FitzRoy's successor, arrived in New Zealand in late 1845 and had brought that conflict to an end by January 1846, when some of the chiefs that had been fighting against British troops made peace with the Governor. ${ }^{59}$ In the lower North Island, Ngāti Toa Rangatira Te Rangihaeata had fallen into discord with the Europeans concerning land. James Watkin came in contact with Te Rangihaeata in July 1845, when the chief attended a church service held during a hui (gathering) at Porirua, and Watkin noted: 'He is much hated by many perhaps feared, but he expresses himself as friendly. ${ }^{60}$ The chiefs could not ignore the success of Christianity, which had come to be embraced by many of the people and various chiefs. Even those who did not convert were likely to attend some church services, as was the case here, because they had become an important part of the community.

\footnotetext{
${ }^{56}$ Watkin, Journal Vol. 2, 13 January and 3 February 1845, pp. 370, 371.

${ }^{57}$ ibid., 3 and 10 February 1845, pp. 371, 372.

${ }^{58}$ ibid., 31 March 1845, p. 373.

${ }^{59}$ Orange, pp. 121-122.

${ }^{60}$ Watkin, Journal Vol. 2, 16 July 1845, p. 374.
} 
Later in the month, Watkin sighted Te Rangihaeata again when visiting Takapūwāhia to preach and conduct baptisms. Te Rangihaeata informed Watkin that he did not agree with the Governor's arrangements concerning land at the Hutt and that he had never signed the deed, therefore his signature must have been forged. While noting that this was a serious matter, Watkin recorded having exhorted Te Rangihaeata 'to renounce heathenism and embrace Christianity, but with little apparent effect. ${ }^{, 61}$ Amidst the conflict, to the minister of religion accepting Christianity remained the central issue of concern. Watkin therefore encouraged chiefs to adopt Christianity, knowing that their conversion had the potential to influence others in the tribe. Even when they did not commit to Christianity immediately, the chance always remained of them being converted in later years. Although hostilities over land at the Hutt continued in the year following and Te Rangihaeata was never converted, he did become a churchgoer, before dying from pneumonia in November $1855 .{ }^{62}$ If chiefs were to embrace Christianity, the peaceful sentiments encouraged by it could thereby be diffused throughout the tribe. This had the potential to improve intertribal relations, as if chiefs from differing tribes came to identify as Wesleyan, their faith would become an area of common ground and one upon which they could unite.

Some of the chiefs and missionaries were in unison in wishing to allay tensions. Early in 1845, the chiefs of Te Aro Pā sent a letter to the Rev. Ironside assuring him of the amiable sentiments held by Māori of Port Nicholson and Waikanae, and the New Zealand Spectator published the translated letter on 12 April $1845 .{ }^{63}$ It read:

Sir-Mr. Ironside, This is our korero to you. We will not follow the bad example of those strangers at the North. The Natives of Port Nicholson and Waikanae will die together with the Europeans, if this wickedness should grow and spread. All we wish to fight with is sin, that the world may become peaceful and happy, under the rule of the great God of heaven and of Jesus Christ. Friend, We love you ministers, and we love the other Europeans, all of them; they are our friends and neighbours. We requested the Europeans to come and dwell here in Port Nicholson. Friend, Major

Richmond, Let your thoughts towards us be good; do not have an evil heart towards us; rather

\footnotetext{
${ }^{61}$ ibid., 28 July 1845, p. 375.

${ }^{62}$ Angela Ballara, 'Te Rangihaeata', from the Dictionary of New Zealand Biography, Te Ara - the Encyclopedia of New Zealand, updated 30 October 2012, available from: http://www.TeAra.govt.nz/en/biographies/1t63/terangihaeata

${ }^{63}$ Pratt, 'Rev. Samuel Ironside’, p. 25.
} 
rejoice in hope, be patient in tribulation, continue instant in prayer. Let this our letter be given to the press, and printed in the newspaper. This is all our korero.

From HOPEKA, and others. ${ }^{64}$

These chiefs had accepted Christianity and the gospel and their letter expressed the same peaceable notions encouraged by it. Communicating with clearly Christian themes, they wrote of prioritising the spiritual battle with sin above the temporal battles raging in the North. Ka'ai et al. noted that Māori addressed concerns to government through letters and newspapers and: 'In doing so, they developed styles of writing based upon whaikōrero, incorporating oral literature such as song and proverbs, as well as biblical references. ${ }^{65}$ The above letter is an example of this, referencing the Bible verse of Romans 12.12: 'Rejoicing in hope; patient in tribulation; continuing instant in prayer' (KJV). The Te Aro chiefs' letter may have been written in this style as a reflection of how they had learnt literacy from the missionaries, this letter was directed first to a missionary, and they may have identified this as an effective way to clearly convey their peaceable sentiments towards the European settlers.

\section{Church gatherings}

By visiting each part of the circuit to which the missionary was assigned, Watkin helped to strengthen the people in Christianity throughout the area and to form ties between himself and the people there. For example, on 12 December 1843 Watkin and a Māori crew voyaged south by boat to Ōtākou, where he preached and catechised the people at Te Ruatitiko in the evening. The next morning he conducted baptisms and marriages, met with members of the society and gave tickets. ${ }^{66}$ Afterwards he visited Tahakopa and conducted baptisms and marriages, before holding a service at Tawhiroko. On the $14^{\text {th }}$ of December they went to Pūrākaunui, where Watkin conducted a few more church services, baptisms and marriages. ${ }^{67}$ By visiting these locations, Watkin strengthened his connection with the congregations there.

\footnotetext{
64 'Notice', New Zealand Spectator and Cook's Strait Guardian, 12 April 1845, p. 1.

${ }^{65}$ T. M. Ka‘ai, J. C. Moorfield, M. P. J. Reilly, S. Mosley, Ki te Whaiao: An Introduction to Māori Culture and Society (Auckland: Pearson Education New Zealand, 2004), p. 149.

${ }^{66}$ Tickets of membership were issued on a quarterly basis, originally used to restrict admission to Wesleyan society meetings, love-feasts and the Covenant Service. John A. Vickers, 'Class tickets', Dictionary of Methodism in Britain and Ireland, Wesley Historical Society, accessed 26 July 2015, available from http://www.wesleyhistoricalsociety.org.uk/dmbi/index.php?do=app.entry\&id=634
}

${ }^{67}$ Watkin, Journal Vol. 2, 16 December 1843, pp. 359, 360. 
The following week, people from across the circuit visited Karitāne to attend the love-feast (a Wesleyan communal meal) and partake of the Sacrament. ${ }^{68}$ On the $24^{\text {th }}$ of December, Watkin conducted a service to a crowd, which he estimated at possibly two hundred, and he baptised more than forty persons, while he reported that Christmas day services were well attended. ${ }^{69}$ The people had been receptive to Watkin's visit, which encouraged them to attend the special services being held at Karitāne in return. At these church gatherings, Māori Wesleyans from the various localities met together, providing an environment within which amiable sentiments were likely to be fostered between them.

In Wellington also, the missionaries recognised the importance of visiting each area of the circuit. Samuel Ironside described the Wellington circuit as: 'wide, including at least one hundred and fifty miles of coast line, with the various intersecting valleys. All the places within these bounds were periodically visited. ${ }^{70}$ Ironside's charge included all the villages around Wellington, Porirua, Mana, to Wairarapa in the east, and north along the coast to Rangitīkei, Turakina and Whangaehu. ${ }^{71}$ James Watkin regularly conducted services at Te Aro, Karori, Porirua, Lower Hutt which he would ride to on horseback, and he also visited Takapūwāhia, Te Paripari, and Ngauranga where there were a few Māori members of the Wesleyan Society. ${ }^{72}$ He travelled to areas further away in the circuit, visiting Waikanae in May 1845 and various villages on the way back, having intended to visit Rangitîkei but being unable to due to the sickness of one of his two Māori travel companions. ${ }^{73}$ Missionaries often travelled with Māori companions on longer distance journeys, and hereby Māori provided vital assistance which made the spread of Christianity in New Zealand possible.

\footnotetext{
${ }^{68}$ ibid., 23 December 1843, p. 360; Herbert McGonigle, 'Love-feast', Dictionary of Methodism in Britain and Ireland, Wesley Historical Society, accessed 22 August 2015, available from http://www.wesleyhistoricalsociety.org.uk/dmbi/index.php?do=app.entry\&id=1747

${ }^{69}$ Watkin, Journal Vol. 2, 26 December 1843, p. 361.

${ }^{70}$ Samuel Ironside, 'A Biography of James Watkin: A pioneer Missionary in the Friendly Islands and in New Zealand, Ex-President of the Australian Conference', The Wesleyan-Methodist Magazine, October 1891, p. 734.

${ }^{71}$ Pratt, 'Rev. Samuel Ironside', p. 24.

${ }^{72}$ Watkin, Journal Vol. 2, 16 June 1845, 14 December 1846, 18 January 1847, pp. 374, 379, 380.

73 ibid., 31 May 1845, p. 374.
} 
James Watkin also ventured further afield while stationed at Wellington, several times travelling north for the District Meeting which was attended by the Wesleyan missionaries. ${ }^{74}$ In 1844, he travelled via Auckland to Kāwhia for the District Meeting. On return, after a week of journeying home Watkin reached Henry Hanson Turton's mission station at New Plymouth, where his health broke down. James Watkin consequently spent eight weeks at New Plymouth while waiting for a return vessel to Wellington. While there, Watkin helped Turton to form a Missionary Society and he preached while Turton visited outposts. ${ }^{75}$ In October 1851, Watkin visited Canterbury in the South Island after it was added to the Wellington circuit. There he baptised a total of more than sixty Māori adults and Māori and European children at Rāpaki, Wakaoroi, Pigeon Bay, Lyttelton, Taumutu Pā, and Kaiapoi. ${ }^{76}$ Through these visits the missionary was able to encourage the people in Christianity, while keeping informed on and overseeing the progress of the Wesleyan churches. Visitors also came to Wellington, for example Watkin noted that Māori from different parts of the coast were present when he preached on 3 January $1847 .{ }^{77}$ By the missionary visiting other churches and Wesleyans of other congregations visiting Wellington, links were built up between the congregations. This helped to foster peace between the Wesleyan Māori of differing tribes, by connecting them through their shared faith and church practices.

Church gatherings also provided an opportunity for peaceful sentiments to be fostered among those in attendance. Pratt stated that the Revs. James Watkin and Samuel Ironside arranged a hui each quarter, as a time when Māori could gather for worship, examination and baptism. While New Zealand remained in an unsettled state, Europeans sometimes misjudged the gatherings but later perceived their role in promoting peaceful relations over hostility. ${ }^{78}$ On the week in which the missionaries had a hui planned for in July 1845, The New Zealand Spectator and Cook's Strait Guardian newspaper printed a paragraph giving the impression that the meeting was for political purposes, failing to mention its religious intent at all. It

\footnotetext{
74 ibid., 29 November 1844 and 19 October 1846, pp. 368, 378.

${ }^{75}$ James Watkin, Letter to the Secretaries of the Wesleyan Missions, 6 December 1844, Methodist Missionary Society Records, Reference Number: Micro-163, Reel 22, Hocken Collections, University of Otago, p. 2.

${ }^{76}$ Major Albert Rugby Pratt, 'Early Methodism in Canterbury', The New Zealand Methodist Times, 18 May 1940, p. 27.

${ }^{77}$ Watkin, Journal Vol. 2, 4 January 1847, p. 380.

${ }^{78}$ Pratt, 'Rev. Samuel Ironside', p. 24.
} 
stated that Māori from different tribes in the Southern District would gather at Porirua, in what was expected to be the largest meeting in five years to take place in that part of the North Island. The newspaper claimed that although Te Rauparaha was not planning to attend, Hōne Heke would submit a letter to the meeting explaining his plans and inviting the southern tribes to make common cause with him. ${ }^{79}$ The government had been quarrelling with Ngāpuhi chief Hōne Wiremu Heke Pōkai since July of 1844, when he had the flagstaff bearing the Union Jack on Maiki Hill at Russell cut down, in what was seen as a challenge to British sovereignty. ${ }^{80}$ The flagstaff was replaced and cut down again twice in January 1845 and for the final time in March, at which point fighting commenced between Māori supporting Heke and British troops, resulting in the desertion of Kororāreka and its subsequent destruction. ${ }^{81}$ These events worried the settlers, and Watkin and Ironside were sure to reply to the newspaper, which printed their letter response the following week. The missionaries' asserted that their gathering was for religious and not political purposes and had been planned more than six months before. Their letter continued:

At that time Kororarika [Kororāreka] was standing, and there was no apprehension of danger here. Further, so far from these southern natives having any communications with Heki [Heke], it is doubtful whether they would have ever heard of his name had it not been through the medium of the newspapers. There is no ground for suspicion of evil from our maori [sic] neighbours, as they are all friendly disposed towards the settlers, and will remain so as far as we have an opportunity of judging. While every proper precaution is taken against danger, ought we not to deprecate the indulgence of these groundless suspicions, as likely to bring about the thing that is feared? $?^{82}$

In this letter the missionaries sought to clarify the misunderstanding and to allay the needless and unfounded fears of the settlers, which would only contribute to hostilities. This was another way in which Watkin worked to foster peace between settlers and Māori, by encouraging the settlers around Wellington to subside from paying undue heed to mistruths.

\footnotetext{
${ }^{79}$ The New Zealand Spectator and Cook's Strait Guardian, 12 July 1845, p. 2.

${ }^{80}$ Allan K. Davidson, Christianity in Aotearoa: A History of Church and Society in New Zealand (Wellington: The New Zealand Education for Ministry Board, 2004), p. 26.

${ }^{81}$ Orange, pp. 115-116; Freda Rankin Kawharu, 'Heke Pokai, Hone Wiremu', from the Dictionary of New Zealand Biography, Te Ara - the Encyclopedia of New Zealand, updated 30 October 2012, available from http://www.TeAra.govt.nz/en/biographies/1h16/heke-pokai-hone-wiremu
}

\footnotetext{
82 James Watkin and Samuel Ironside, 'To the Editor of the New Zealand Spectator', The New Zealand Spectator and Cook's Strait Guardian, 19 July 1845, p. 3.
} 
Watkin sought to assure the settlers that there was no need to suspect local Māori of wishing to do them harm, when their intent was instead one of goodwill and in favour of peace. He believed that the settlers' distrust tied into the fact that they did not understand Māori language or habits, while it was in keeping with Māori interests to preserve their European neighbours. ${ }^{83}$ Misunderstandings could be like fuel to the fire of hostilities, and therefore clearly conveying each side's true sentiments was important for helping to ease racial tensions and to encourage peace in its stead.

If there was any extra intent behind the July 1845 hui planned by the missionaries, it was for the purpose of encouraging intertribal peace. In a letter to the WMS the following month, Samuel Ironside reported that the hui went from 11 to 15 July and was attended by 1,500 or more adults. He explained that its purpose was:

to know their progress in Scripture and Catechisms and also as the affairs of New Zealand were taking such a turn for the worse, we wished to get the different tribes under our care together at one place, to hack [?] down prejudices, which one tribe might have against another, and bring about a more close union between themselves and us. ${ }^{84}$

The missionaries intended for the gathering to break down barriers that could be building between tribes, in light of the ongoing conflicts being experienced in the North Island. They also hoped to strengthen the relationship that Māori had with the missionaries and church. Māori of differing tribes and areas came together for the hui, at which the Wesleyans united in attending combined worship services. Māori from different churches attended as well but held their own worship separate from the Wesleyan services; Watkin believed that by doing so they were following the advice of Pākehā from their church and acting against their own better feeling. ${ }^{85}$ On the occasion, Watkin and Ironside baptised thirty to forty people including children, married seven couples, preached, dispensed the Lord's Supper to more than one hundred and examined the peoples' knowledge of scripture and the catechism. ${ }^{86}$

\footnotetext{
${ }^{83}$ James Watkin, Letter to the Secretaries of the Wesleyan Missions - Journal Extracts, August 1845, Methodist Missionary Society Records, Reference Number: Micro-163, Reel 22, Hocken Collections, University of Otago, p. 6.

${ }^{84}$ Samuel Ironside, Letter to the Secretaries of the Wesleyan Missions, 5 August 1845, Methodist Missionary Society Records, Reference Number: Micro-163, Reel 22, Hocken Collections, University of Otago, p. 3.

${ }^{85}$ Watkin, Letter to the Secretaries of the Wesleyan Missions - Journal Extracts, August 1845, p. 6.

${ }^{86}$ Watkin, Journal Vol. 2, 16 July 1845, p. 374.
} 
There was an abundance of provisions, with Watkin noting that: 'The feast was a large one, the pile of food little less than a quarter of a mile long, consisting of thousands of baskets of potatoes and other fruits of the ground, with fish in vast number. There was a little hill of loaves, and a canoe nearly full of porridge. ${ }^{87}$ At this hui, originally planned by the missionaries and put into effect by local Māori, the members of different tribes, areas and denominations joined in eating and conversing together; the Wesleyans combined in church services as well. While the effects of other developments across the country threatened to divide Māori and create discord, events such as this church gathering facilitated the enhancement of amiable feelings and understanding between them.

\footnotetext{
${ }^{87}$ Watkin, Letter to the Secretaries of the Wesleyan Missions - Journal Extracts, August 1845, p. 6.
} 


\section{Conclusion}

During missionary James Watkin's time in New Zealand from 1840 to 1855 , he laboured to diffuse the Christian gospel and thereby he encouraged the cause of physical and moral peace among Māori and Europeans in the Karitāne and Wellington circuits. Chapter one has considered how Watkin fostered peace in the local community by spreading Biblical teachings conducive to peace, through preaching and conducting schools. Firstly, in relation to preaching, Watkin located his family nearby those that they wished to influence and applied himself to learning te reo Māori, which was essential for effectively communicating the gospel to Māori and assisting the progress of the mission among them. Watkin conversed with local Māori to enhance their understanding of Christianity and his own understanding of the society within which he was operating. With Kāi Tahu assistance he became competent in the local dialect and preached to Māori and European congregations at places including Karitāne, Mataīnaka and Moeraki. Watkin sowed the gospel of peace in his work without knowing whether the seed would spring up or wither among his hearers. However, amidst many discouragements he sometimes caught glimpses of its effects, such as when one man refused to fight another as a result of the missionary's teachings. Watkin also encouraged moral peace by preaching against habitual drunkenness, which was a serious problem among foreigners at Otago and tied into other issues such as theft. Individuals had needlessly perished from causes linked to the habit, inflicting disruption upon their families; by discouraging the practice, Watkin encouraged the moral peace of families and the health of the community. One of the reasons why John Jones had brought the missionary to Karitāne was to have a positive moral influence upon its inhabitants, many of whom were his employees, and it was therefore in the whaling station owner's interest to minimise strife and misconduct in the locality.

More Māori around Karitāne gradually entered into baptism and by 1843 baptisms were frequently taking place. Converts included commoners and rangatira, many of whom assumed new responsibilities as church leaders and teachers, even establishing churches and schools in the areas where they lived. Although chiefs ruled with their community's consent, they were influential among their people, which made their own conversions particularly useful for encouraging Christianity and its peaceful notions. The progress of Christian missions among Māori in the North Island facilitated its acceptance in the South Island, and 
the southern chief Tūhawaiki was among those to request a missionary, for his people on Ruapuke Island. Tūhawaiki recognised the advantages that his people stood to gain from attaining literacy, knowledge of Christianity, and skills from the mission, which would better enable them to adapt to the societal changes taking place with increasing rapidity, as a result of the increased migration of foreigners into New Zealand. Māori teachers, eager to share their newly attained knowledge from the missions, also played a fundamental role in spreading Christianity and looking after congregations which could be out of the immediate reach of the missionary.

Secondly, James Watkin established schools which were another crucial mechanism for encouraging knowledge and acceptance of Christianity among Māori. Watkin's schools taught male and female Māori, of all ages and ranks in attendance, reading and writing skills in their own language. As the missionary had to translate texts for the schools into the local dialect, his language skills were of key import. Once basic literacy was attained, the missionary supplied Māori with religious texts and Bibles, which enabled Christian ideas in favour of physical and moral peace to gain greater circulation and currency in local communities. The missionary's family as a whole played an important role in the functioning of the mission station; his older children assisted at the schools, while Hannah Watkin taught Māori girls and women skills of practical use in areas such as sewing, hygiene, childcare and cooking. This also provided Māori with insight into the European way of living, allowing them greater understanding of the foreigners who were increasingly entering Aotearoa.

When Māori New Testaments arrived at Karitāne they were readily acquired by Kāi Tahu, who placed value upon them equal to that previously bestowed upon introduced European weapons. Bible classes were held and those able to read acquired new knowledge from the book. The Bible was the central text upon which Protestant Christianity founded its beliefs; consequently by reading this Māori were becoming acquainted with a higher source of authority on Christianity than that of the missionaries themselves. Māori combined what they had learnt at the mission station by using their literacy to write letters expressing their Christianity and making enquiries or requests to the missionary, as well as writing letters to one another, to contacts in the North Island and to government officials. By teaching literacy, the missionary helped to provide a peaceful way in which Māori could interact with the government to express their grievances by letters and petitions. It also provided them with a way of disseminating and clarifying their views to settlers, when for example they wrote into 
local newspapers. One of Watkin's teachers at Moeraki, the chief and tohunga Matiaha Tiramōrehu, used writing to express his complaints concerning South Island land sales and his efforts added support to Te Kerēme, which was later resolved particularly by the 1998 Ngāi Tahu Claims Settlement Act. James Watkin's efforts to instil Christian teachings among Māori contributed to the peaceful sale of the Otago block of land, signed onto by many chiefs that were Wesleyan converts and received payment in cash and not arms; however, Watkin's views on colonisation remained ambivalent. He perceived the ways in which Māori were both advantaged and harmed by it, although his main concern was for their spiritual welfare and the progress of Christianity among them. At Wellington, Watkin continued to promote the moral peace of the community, as evidenced by his involvement in a Wellington Evangelical Alliance petition against the proposal of New Zealand receiving convicts from Britain. By more direct interventions at Karitāne, namely by acting to deter the potential sacrifice of a captive and to discourage violence against infants and children, Watkin took a clear stand to support physical peace for all ranks of society. He encouraged interracial harmony when he buried a deceased Māori woman in the Christian burial grounds despite the opposition of some Europeans, and after a few years Watkin believed that race relations had improved at Karitāne as a result of his coming to the area. If the foreigners did not wish to follow the minister's preaching advice, they at least paid greater heed to his threats of informing the magistrate at Akaroa of their conduct, and he thereby had a restraining influence upon them.

Chapter two focused on how James Watkin helped to foster peace in times of war. When Watkin arrived in the South Island, Kāi Tahu were still recovering from the recently experienced wars with Te Rauparaha and from the effects of diseases introduced by Europeans, both of which had significantly afflicted the Māori population. These experiences helped to reinforce the need for physical peace to preserve what remained, and Christianity offered an alternative to warfare and reasons for exalting peace in its place. Te Rauparaha's son Tāmihana adopted Christianity in association with the CMS and travelled around the South Island with his cousin Te Whiwhi, informing Kāi Tahu of the gospel while simultaneously conveying a message of peace from Ngāti Toa to their former foes. Christianity contributed to traditional forms of peace making, such as those of marriage alliances between tribes and the releasing of war captives, the latter of which also aided the spread of Christianity southward in the North Island especially. The mission teachings on hygiene and the promotion of stable over transitory relationships also encouraged the physical health of the local population, by helping to minimise malady related deaths. The 
increased pressures of colonisation, with associated tensions over land, and the common belief that the Māori population was at risk, also worked to underline the need for peace in order to preserve Māori and to assist both Māori and Europeans with making positive progress into the future.

Missionaries additionally helped to foster peace in time of conflict by mediating between opposing parties. At Karitāne, Watkin's intervention prevented potential violence from taking place when a taua arrived at Waikouaiti Bay. When Māori wished to attain peace, the missionary was a helpful conduit for this; their mediations could bring about peace for both parties, without chiefs and consequently their hapū being perceived as weak and suffering loss of mana in the process. James Watkin also encouraged chiefs in the Wellington region to adopt Christianity, which could favour the cause of peace by uniting Wesleyans from different tribes within a common faith. Chiefs from Te Aro Pā who were associated with the missionaries used their literacy skills to send a letter addressed to the missionary Ironside, also intended for the local newspaper, expressing peaceful sentiments to the European settlers and containing Biblical references. There are various reasons why the chiefs may have written in this way but it nevertheless highlights how there were perceived links between Christianity and the encouragement of peace. James Watkin helped to form ties between his Māori congregants in the areas where he was stationed by visiting various villages within the circuit, which in turn encouraged those located at these villages to visit the more central church. This, along with church gatherings organised by the missionaries, provided occasions in which Māori from different hapū and iwi came together to participate in shared church activities, worship services and meals. These events emphasised the similarities that attendees held in common under their shared faith, rather than their differences, and provided conditions favourable to the fostering of peace, acceptance, and improved relations between them. This was a highly beneficial outcome, particularly in light of the conflicts and dissensions taking place within New Zealand at the time. 


\section{James Watkin's later years}

After 1855, the Methodist churches in Australia and New Zealand became an independent Conference. ${ }^{1}$ At the first Australian Wesleyan Methodist Conference in 1855, the Rev. James Watkin was assigned to New South Wales, where he worked for thirteen years at Windsor, Wollongong, Bourke-street, Sydney, Paramatta and for one year at Camden. ${ }^{2}$ Charles Creed and Samuel Ironside subsequently ministered in New South Wales as well, where Watkin was able to see them again. ${ }^{3}$ In 1862, Watkin was the President of the Australian Wesleyan Methodist Conference held in Adelaide, and from April 1868 he worked in the Melbourne suburb of Brighton for one year, before returning to Sydney and becoming a Supernumerary Minister. ${ }^{4}$ In 1869, he and fellow veteran Stephen Rabone were sent by the Conference as a deputation to Tonga and Fiji. There Watkin could see how Tonga had transformed into a largely Christian nation, an outcome towards which his early mission work had contributed. ${ }^{5}$ Watkin spent his final years living on Queen Street in Ashfield, Sydney, in a cottage which he named Waikowaiti after the location of his first New Zealand mission station at Waikouaiti, now known as Karitāne. Clearly the work that had seemed so trying to him at the time was a source of joy in retrospect. Watkin continued to preach until poor eyesight and other frailties made it impracticable. ${ }^{6}$ In late December 1882, Watkin and his son William were fortunate to be among the survivors who safely escaped when the steamer New England wrecked on the Clarence River in New South Wales and eleven perished. ${ }^{7}$ On 17 March 1886, all of James Watkin's family reunited at his home for the first time in thirty-four years,

\footnotetext{
${ }^{1}$ M. A. Rugby Pratt, The Pioneering Days of Southern Maoriland (London: Epworth Press, 1932), p. 214.

${ }^{2}$ Samuel Ironside, 'A Biography of James Watkin: A pioneer Missionary in the Friendly Islands and in New Zealand, Ex-President of the Australian Conference', The Wesleyan-Methodist Magazine, October 1891, pp. 734-735.

${ }^{3}$ James Watkin, Journal of James Watkin, Vol. 2, 1840-1882, Reference Number: fMS-255, Alexander Turnbull Library, 23 June 1856 and 10 September 1858, pp. 408, 441.

${ }^{4}$ Ironside, p. 735; Watkin, Journal Vol. 2, 9 April 1869, p. 562.

${ }^{5}$ People Information files, Rev James Watkin, Methodist Church of New Zealand Archives; 'THE LATE REV. JAS. WATKIN', Evening Post, 5 June 1886, p. 1.

6 'The Late Rev. James Watkin.', Illustrated Sydney News, 15 June 1886, pp. 3, 10.

7 'Wrecks on the Coast of New South Wales during the Year 1882', The Maitland Mercury and Hunter River General Advertiser, 7 April 1883, Third sheet p. 1; Ironside, p. 736.
} 
including his six sons, two daughters and thirty other relatives. ${ }^{8}$ Their youngest son Samuel Ironside Watkin had died at the early age of thirty, his namesake recorded: 'after giving rich intellectual and spiritual promise'. ${ }^{9}$ Three of James Watkin's sons were ministers, Dr Edwin Iredale in Victoria, William Jackson in New Zealand, and Jabez Bunting was President of the Free Church of Tonga. Watkin's youngest daughter Lucy married a Wesleyan minister named Richard East in New South Wales. John Wesley Watkin was Mayor of Ashfield, Sydney, in 1884, then his older brother Joseph Hebblewhite Watkin was Mayor of Ashfield in 1888, and they both partnered in the Sydney real estate firm Watkin and Watkin. James Entwisle ran an ironmongers shop in Wellington and later became a member of the Watkin and Watkin firm in Sydney. ${ }^{10}$ James Watkin's children fulfilled roles in the church and community in Tonga, New Zealand and Australia, just as he had done.

On 14 May 1886, James Watkin passed away peacefully at his home at the age of eighty, his last words being the benediction. The Rev. J. H. Fletcher conducted his memorial service, remarking on James Watkin's turn for satire as well as his kindness, courtesy and unselfish and lovable character. ${ }^{11}$ Watkin was buried at the Rookwood Cemetery in New South Wales, a few yards away from the grave of the Rev. Charles Creed. ${ }^{12}$ Two years later, Watkin's eldest daughter Hannah Jane Cadden passed away aged fifty-three, and on 16 February 1900 James Watkin's widow Hannah Watkin died around the age of ninety-four. ${ }^{13}$ Newspapers in Australia and New Zealand reported on the passing of James Watkin and later of his wife. For Hannah Watkin, it was noted that she had led an exemplary life as a missionary and minister's wife, toiled uncomplainingly in faithful service, was 'a tower of strength to her

\footnotetext{
${ }^{8}$ M. A. Rugby Pratt, 'JAMES WATKIN: Otago's Religious Pioneer', The Evening Star, 16 May 1928, Alexander Turnbull Library, p. 4.

${ }^{9}$ Ironside, p. 734.

${ }^{10}$ Rita F. Snowden, 'The Home Circle', The New Zealand Methodist Times, 18 May 1940, p. 31; 'THE LATE REV. JAS. WATKIN', p. 1; 'DEATH OF THE REV. J. WATKIN', Wanganui Chronicle, 29 May 1886, p. 2.

${ }^{11}$ Ironside, pp. 736-737.

12 Pratt, ‘JAMES WATKIN: Otago’s Religious Pioneer', p. 4.

13 'Family Notices', The Sydney Morning Herald, 20 April 1888, p. 1; 'Family Notices', The Sydney Morning Herald, 17 February 1900, p. 1; J. M. R. Owens, The Wesleyan Missionaries to New Zealand Before 1840 (Tauranga: Don Kale Printing Co. Ltd, 1982), p. 24. Owens stated that Mrs Hannah Watkin died aged ninetythree, while the newspaper reports stated that she was ninety-four years old.
} 
husband in his missionary labors' and 'the mother of an illustrious family'. ${ }^{14}$ Of James Watkin, the Illustrated Sydney News stated that:

His range of reading was extensive, his conversational powers were of a high order, and his powers of humour and sarcasm made his conversation in private circles and his addresses from the platform very effective. The church of which he was for so many years a minister has never had among its clergymen one who was more widely respected. ${ }^{15}$

Ninety-nine years after James Watkin arrived in the South Island, anniversary services were held on Karitāne beach and in the church at night, attended by many Māori and others. ${ }^{16}$ The following year being 1940, commemorations marked one hundred years since the establishment of the first Christian mission in the South Island and the Treaty of Waitangi. James Watkin's granddaughter assisted in laying a foundation stone at the site of the Ōtākou Māori Centennial church as part of the celebration. ${ }^{17}$ A leadlight window within the church was inscribed: 'To the Glory of God and in Memory of the Pioneer Missionaries, Native teachers and Pastors who established in these parts the first Christian Mission, commencing with the arrival of the Rev. James Watkin at Waikouaiti on May 16th. 1840. ${ }^{18}$ James Watkin was long gone but not forgotten; his work for the church was continued by his children and had effectively strengthened the cause of Christianity in the South Pacific, New Zealand and Australia. If further research or a full length book was written on James Watkin, of which there is sufficient material to support from key sources such as his lengthy journal and letters sent to the WMS, it would be beneficial if this could examine his whole time as a missionary covering his work in Tonga, New Zealand and Australia in greater detail, particularly the first and latter location which have not received as much attention. This would allow for a more complete overview of his career as a missionary, and may shed greater light on the character and development of nineteenth-century missionary efforts in the South Pacific.

\footnotetext{
14 'A Prelatic Difficulty', Australian Town and Country Journal, 24 February 1900, p. 8; 'A PIONEER OF CIVILISATION IN THE SOUTHERN PACIFIC. DEATH OF MRS. HANNAH WATKIN.', Albury Banner and Wodonga Express, 23 February 1900, p. 33.

15 'The Late Rev. James Watkin.', p. 10.

16 ‘ARRIVED 99 YEARS AGO’, Auckland Star, 18 May 1939, p. 13.

17 'Otakou Maori Centennial 1840-1940: Foundation Stone Laying Ceremony’ (Dunedin: Otago Daily Times print, 1940), Alexander Turnbull Library; 'METHODIST CHURCH', Evening Post, 6 February 1940, p. 11.

${ }^{18}$ Thomas A. Pybus, Otakou, A Story of Far-off Days (Auckland: Wesley Historical Society of New Zealand, 1941), p. 14.
} 


\section{Bibliography}

\section{$\underline{\text { Primary Sources }}$}

\section{Books}

Copy of Watkin, James: Vocabulary of Maori Words, Reference Number: PC-0038, Hocken Collections, University of Otago.

Shortland, Edward, The Southern Districts of New Zealand; A Journal, with Passing Notices of the Customs of the Aborigines (Christchurch: Caper Press, 1974).

Wesley, John, The Works of the Rev. John Wesley, Vol. 5 (New York: J. \& J. Harper, 1826).

\section{Journal Article}

Watkin, James, 'An Appeal to the Sympathy of the Christian Public, on Behalf of the Cannibal Fegeeans', The Wesleyan-Methodist magazine, Vol. 17, February 1838, pp. 150152.

\section{Letters}

Fairclough, Paul W., Copy of Extracts from letters to Rev Samuel Ironside, Cloudy Bay \& Wellington, from Rev James Watkin, Waikouaiti 1 June 1841, Catalogue No. MS208, Methodist Church of New Zealand Archives, 1902.

Methodist Missionary Society Records, Reference Number: Micro-163, Reels 20-25, Hocken Collections, University of Otago.

Watkin, James, Letters to James Buller, Catalogue No. MS207, Methodist Church of New Zealand Archives, 1840-1844.

\section{Manuscripts}

Porter, Frances, Transcription of Eliza White Journals 16 September 1829-28 April 1836, Reference Number: MSDL-0123, Alexander Turnbull Library, 2004.

Watkin, James, Journal of James Watkin, Vol. 1, 1830-1839, Reference Number: fMS-254, Alexander Turnbull Library.

Watkin, James, Journal of James Watkin, Vol. 2, 1840-1882, Reference Number: fMS-255, Alexander Turnbull Library. 
Watkin, James, Sermon notes, Catalogue number: MS210, Methodist Church of New Zealand Archives.

\section{Newspaper}

The New Zealand Spectator and Cook's Strait Guardian

\section{Reports}

'Minutes of the Candidates Committee, 1829-41', Methodist Missionary Society Records, Reference Number: Micro-163, Reel 49, Hocken Collections, University of Otago.

Report from the Select Committee appointed to Inquire into the Statements contained in the Petition of the Merchants, Bankers, and Shipowners of the City of London, (Presented 22d May 1840,) respecting the Colonization of New Zealand; together with the Minutes of Evidence taken before them, and an Appendix and Index. (London: House of Commons, 1840).

\section{$\underline{\text { Secondary Sources }}$}

\section{Booklets}

'Otakou Maori Centennial 1840-1940: Foundation Stone Laying Ceremony' (Dunedin: Otago Daily Times print, 1940), Alexander Turnbull Library.

Pybus, Thomas A., 'Heroic Pioneer Workers' (Dunedin: Otago Daily Times print, 1940), Alexander Turnbull Library.

Pybus, Thomas A., 'Otakou and the First Christian Mission: A Brief Statement' (Dunedin: Otago Daily Times print, 1940), Alexander Turnbull Library.

\section{Books}

Anderson, Atholl, The Welcome of Strangers: An ethnohistory of Maori A.D. 1650-1850 (Dunedin: University of Otago Press, 1998).

Ballantyne, Tony, Entanglements of Empire: Missionaries, Māori, and the Question of the Body (Auckland: Auckland University Press, 2015).

Barry, Amanda et al. (eds.), Evangelists of Empire?: Missionaries in Colonial History (Melbourne: eScholarship Research Centre, 2008). 
Belmer, Roy, James Watkin: Pioneer Missionary (Auckland: Wesley Historical Society of New Zealand, 1979).

Broad, Lowther, The Jubilee History of Nelson: From 1842 to 1892 (Nelson: Bond and Finney, and Co, 1892).

Brock, Peggy (ed.), Indigenous Peoples and Religious Change (Leiden and Boston: Brill, 2005).

Carey, Hilary M., God's Empire: Religion and Colonialism in the British World, c.1801-1908 (Cambridge: Cambridge University Press, 2011).

Carter, George G., A Family Affair: A Brief Survey of New Zealand Methodism's Involvement in Mission Overseas 1822-1972 (Auckland: Wesley Historical Society of New Zealand, 1973).

Chambers, Wesley A., Samuel Ironside in New Zealand 1839-1858 (Auckland: Ray Richards Publisher, 1982).

Christie, John, History of Waikouaiti, $2^{\text {nd }}$ edition (Christchurch: Christchurch Press Company Limited, 1929).

Coney, Sandra, 'Eliza White' in Charlotte Macdonald, Merimeri Penfold and Bridget Williams (eds.), The Book of New Zealand Women: Ko Kui Ma Te Kaupapa (Wellington: Bridget Williams Books Limited, 1991).

Davidson, Allan K., Christianity in Aotearoa: A History of Church and Society in New Zealand (Wellington: The New Zealand Education for Ministry Board, 2004).

Evison, Harry C., Te Wai Pounamu - The Greenstone Island: A History of the Southern Maori during the European Colonization of New Zealand (Wellington and Christchurch: Aoraki Press, 1993).

Hiroa, Te Rangi, The Coming of the Maori (Wellington: Maori Purposes Fund Board, 1949).

Hocken, Thomas Morland, Contributions to the Early History of New Zealand (Settlement of Otago), (London: Sampson Low, Marston and Company, 1898).

Jones, Alison and Jenkins, Kuni, He Kōrero - Words Between Us: First Māori-Pākehā Conversations on Paper (Wellington: Huia, 2011).

Ka'ai, T. M., Moorfield, J. C., Reilly, M. P. J. and Mosley, S., Ki te Whaiao: An Introduction to Māori Culture and Society (Auckland: Pearson Education New Zealand, 2004). 
Laurenson, George I., Te Hahi Weteriana: Three Half Centuries of the Methodist Maori Missions, 1822-1972 (Auckland: Wesley Historical Society of New Zealand, 1972).

McNab, Robert, The Old Whaling Days: A History of Southern New Zealand from 1830 to 1840 (Wellington: Whitcombe and Tombs Limited, 1913).

Mead, Hirini Moko, Tikanga Māori: Living by Māori Values (Wellington: Huia, 2003).

Olssen, Erik, A History of Otago (Dunedin: John McIndoe, 1984).

Olsson, Arthur Leslie, Raupo Chapel to Multi-Racial Community 1839 to 2005: A Chronology with some Early Recollections marking the $125^{\text {th }}$ Anniversary of the Opening of the Wesley Church in Taranaki Street, Wellington (Wellington: Philip Garside Publishing, 2005).

O’Malley, Vincent, The Meeting Place: Māori and Pākehā Encounters, 1642-1840 (Auckland: Auckland University Press, 2012).

Orange, Claudia, The Treaty of Waitangi, 2nd ed. (Wellington: Bridget Williams Books, 2011).

O’Regan, Hana, Ko Tahu, Ko Au: Kāi Tahu Tribal Identity (Christchurch: Horomaka Publishing, 2001).

Owens, J. M. R., The Wesleyan Missionaries to New Zealand Before 1840 (Tauranga: Don Kale Printing Co. Ltd, 1982).

Parsons, Timothy, The British Imperial Century, 1815-1914: A World History Perspective (Oxford: Rowman \& Littlefield, 1999).

Petrie, Hazel, Outcasts of the Gods? The Struggle over Slavery in Māori New Zealand (Auckland: Auckland University Press, 2015).

Porter, Andrew, Religion versus empire? British Protestant missionaries and overseas expansion, 1700-1914 (Manchester and New York: Manchester University Press, 2004).

Pratt, M. A. Rugby, The Pioneering Days of Southern Maoriland (London: Epworth Press, 1932).

Pybus, Thomas A., Maori and Missionary: Early Christian Missions in the South Island of New Zealand (Wellington: Reed Publishing, 1954).

Pybus, Thomas A., Otakou, A Story of Far-off Days (Auckland: Wesley Historical Society of New Zealand, 1941). 
Richmond, Oliver P., The Transformation of Peace (New York: Palgrave Macmillan, 2005).

Samson, Jane, 'Translation Teams: Missionaries, Islanders, and the Reduction of Languages in the Pacific' in Patricia Grimshaw and Andrew May (eds.), Indigenous Peoples and Cultural Exchange (Eastbourne: Sussex Academic Press, 2010), pp. 96-109.

Smith, Philippa Mein, A Concise History of New Zealand (Melbourne: Cambridge University Press, 2012).

Taylor, W. A., Lore and History of the South Island Maori (Christchurch: Bascands Limited, 1952).

Thorne, Susan, Congregational Missions and the Making of an Imperial Culture in Nineteenth-Century England (Stanford: Stanford University Press, 1999).

Wallace, J. Howard, Manual of New Zealand History (Wellington: Edwards \& Green, 1886).

Wanhalla, Angela, “The Natives Uncivilise Me” Missionaries and Interracial Intimacy in Early New Zealand' in Patricia Grimshaw and Andrew May (eds.), Indigenous Peoples and Cultural Exchange (Eastbourne: Sussex Academic Press, 2010), pp. 24-36.

Williment, T. M. I., John Hobbs 1800-1883: Wesleyan Missionary to the Ngapuhi Tribe of Northern New Zealand (Wellington: Government Printing Office, 1985).

\section{Information File}

People Information files, Rev James Watkin, Methodist Church of New Zealand Archives.

\section{Journal Articles}

Ballantyne, Tony, 'Paper, Pen, and Print: The Transformation of the Kai Tahu Knowledge Order', Comparative Studies in Society and History, Vol. 53, no. 2, 2011, pp. 232-260.

Binney, Judith, 'Christianity and the Maoris to 1840: A Comment', New Zealand Journal of History, Vol. 3, no.2, 1969, pp. 143-165.

Ironside, Samuel, 'A Biography of James Watkin: A pioneer Missionary in the Friendly Islands and in New Zealand, Ex-President of the Australian Conference', The WesleyanMethodist Magazine, October 1891, pp. 730-737.

Latukefu, Sione, 'The case of the Wesleyan Mission in Tonga', Journal de la Société des Océanistes, Vol. 25, 1969, pp. 95-112. 
Middleton, Angela, 'Missionization in New Zealand and Australia: A Comparison', International Journal of Historical Archaeology, Vol. 14, no. 1, 2010, pp. 170-187.

Owens, J. M. R., 'Christianity and the Maoris to 1840', New Zealand Journal of History, Vol. 2, no. 1,1968 , pp. 18-40.

Petrie, Hazel, 'Decoding the Colours of Rank in Māori Society: What might they tell us about perceptions of war captives?', The Journal of the Polynesian Society, Vol. 120, no. 3, 2011, pp. 211-239.

Picker, Gregory, 'A State of Infancy: The Anti-transport Movement in New Zealand, 18481852', New Zealand Journal of History, Vol. 34, no. 2, 2000, pp. 226-240.

Stevens, Michael J., 'Kāi Tahu Writing and Cross-Cultural Communication', Journal of New Zealand Literature, No. 28, Part 2: Special Issue: Cultures of Print in Colonial New Zealand, 2010, pp. 130-157.

\section{Newspapers}

\section{Albury Banner and Wodonga Express}

Auckland Star

Australian Town and Country Journal

Evening Post

Illustrated Sydney News

Otago Daily Times

The Evening Star

The Maitland Mercury and Hunter River General Advertiser

The New Zealand Methodist Times

The Press

The Sydney Morning Herald

Wanganui Chronicle

\section{Theses}

Major, Margaret E., 'Christian Missions in the South Island in the 1840's' (M. A. thesis, University of Canterbury, 1964). 
Ritchie, Samuel G. G., 'Of Red War and Little Else': European Responses to Indigenous Violence in the Tasman World, c.1769-1850s' (Doctoral thesis, Victoria University of Wellington, 2013).

\section{Websites}

Anderson, Atholl, 'Tuhawaiki, Hone', from the Dictionary of New Zealand Biography, Te Ara - the Encyclopedia of New Zealand, updated 11 February 2013, available from http://www.TeAra.govt.nz/en/biographies/1t110/tuhawaiki-hone

Ballara, Angela, 'Te Rangihaeata', from the Dictionary of New Zealand Biography, Te Ara the Encyclopedia of New Zealand, updated 30 October 2012, available from: http://www.TeAra.govt.nz/en/biographies/1t63/te-rangihaeata

Evison, Harry C., 'Tiramorehu, Matiaha', from the Dictionary of New Zealand Biography, Te Ara - the Encyclopedia of New Zealand, updated 30 October 2012, available from: http://www.TeAra.govt.nz/en/biographies/1t100/tiramorehu-matiaha

Kawharu, Freda Rankin, 'Heke Pokai, Hone Wiremu', from the Dictionary of New Zealand Biography, Te Ara - the Encyclopedia of New Zealand, updated 30 October 2012, available from http://www.TeAra.govt.nz/en/biographies/1h16/heke-pokai-hone-wiremu

McGonigle, Herbert, 'Love-feast', Dictionary of Methodism in Britain and Ireland, Wesley Historical Society, accessed 22 August 2015, available from http://www.wesleyhistoricalsociety.org.uk/dmbi/index.php?do=app.entry\&id=1747

Vickers, John A., 'Class tickets', Dictionary of Methodism in Britain and Ireland, Wesley Historical Society, accessed 26 July 2015, available from http://www.wesleyhistoricalsociety.org.uk/dmbi/index.php?do=app.entry\&id=634 